\title{
Indigenous and Traditional Peoples and Protected Areas Principles, Guidelines and Case Studies
}

Edited and coordinated by Javier Beltrán Adrian Phillips, Series Editor

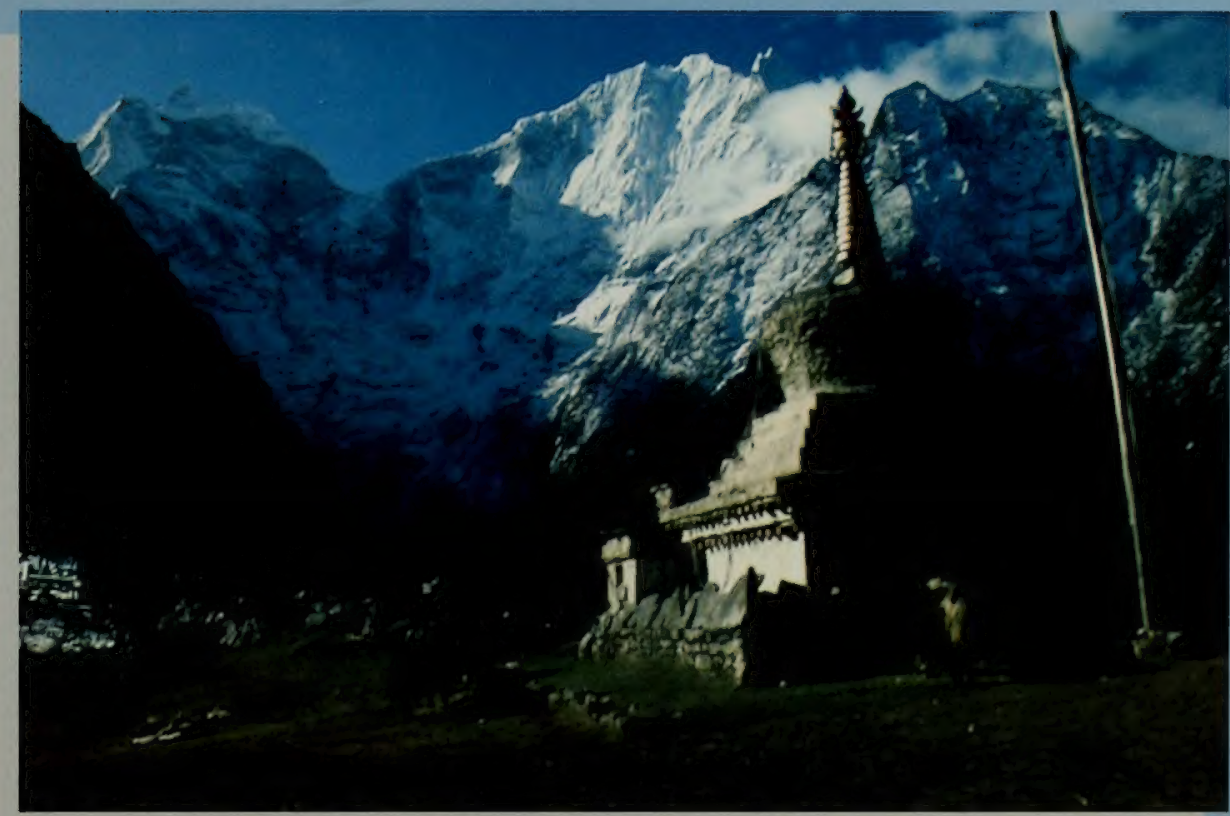

Best Practice Protected Area Guidelines Series No. 4 
These Guidelines are one of the Best Practice Protected Area Guidelines series. The Series Editor is Prof. Adrian Phillips.

Other publications in the series are as follows:

National System Planning for Protected Areas. No. 1. Adrian G. Davey, 1998, $\mathrm{x}+71 \mathrm{pp}$.

Economic Values of Protected Areas: Guidelines for Protected Area Managers. No. 2. Task Force on Economic Benefits of Protected Areas for the World Commission on Protected Areas (WCPA) IUCN in collaboration with the Economics Service Unit of IUCN, 1998, xii + 52pp.

Guidelines for Marine Protected Areas. No. 3. Graeme Kelleher, 1999, xxiv + $107 \mathrm{pp}$.

Financing Protected Areas: Guidelines for Protected Area Managers. No. 5. Financing Protected Areas Task Force of the World Commission on Protected Areas (WCPA) of IUCN, in collaboration with the Economics Unit of IUCN, 2000. viii +58 pp.

Evaluating Effectiveness: A Framework for Assessing the Management of Protected Areas. No. 6. Marc Hockings, Sue Stolton and Nigel Dudley, 2000, x $+121 \mathrm{pp}$. 


\section{Indigenous and Traditional Peoples and Protected Areas}

\section{Principles, Guidelines and Case Studies}




\section{IUCN - The World Conservation Union}

Founded in 1948, The World Conservation Union brings together States, government agencies and a diverse range of non-governmental organizations in a unique world partnership: over 950 members in all, spread across some 139 countries.

As a Union, IUCN seeks to influence, encourage and assist societies throughout the world to conserve the integrity and diversity of nature and to ensure that any use of natural resources is equitable and ecologically sustainable. A central secretariat coordinates the IUCN Programme and serves the Union membership, representing their views on the world stage and providing them with the strategies, services, scientific knowledge and technical support they need to achieve their goals. Through its six Commissions, IUCN draws together over 10,000 expert volunteers in project teams and action groups, focusing in particular on species and biodiversity conservation and the management of habitats and natural resources. The Union has helped many countries to prepare National Conservation Strategies, and demonstrates the application of its knowledge through the field projects it supervises. Operations are increasingly decentralized and are carried forward by an expanding network of regional and country offices, located principally in developing countries.

The World Conservation Union builds on the strengths of its members, networks and partners to enhance their capacity and to support global alliances to safeguard natural resources at local, regional and global levels.

\section{Cardiff University}

The Department of City and Regional Planning, Cardiff University is pleased to be a partner in the production of this important series of guidelines for protected area planning and management. The Department, through its Environmental Planning Research Unit, is actively involved in protected areas research; runs specialised courses on planning and environmental policy; and has a large Graduate School offering opportunities for persons interested in pursuing research for a $\mathrm{PhD}$ or as part of wider career development. If you are interested in learning more about the Department, its research capabilities and courses please write to us at the address given below.

Professor Terry Marsden BAHon., PhD, MRTPI

Head of Department

Department of City and Regional Planning

Cardiff University

Glamorgan Building

King Edward VIIth Avenue

Cardiff, CF10 3WA, Wales, UK

Tel: +442920874022

Fax: + 442920874845

Email: MarsdenTK@cf.ac.uk

Web site: www.cf.ac.uk 


\section{Indigenous and Traditional Peoples and Protected Areas}

\section{Principles, Guidelines and Case Studies}

Edited and coordinated by Javier Beltrán

Series Editor: Adrian Phillips

World Commission on Protected Areas

Best Practice Protected Area Guidelines Series No. 4 
The designation of geographical entities in this book, and the presentation of the material, do not imply the expression of any opinion whatsoever on the part of IUCN, Cardiff University or WWF International concerning the legal status of any country, territory, or area, or of its authorities, or concerning the delimitation of its frontiers or boundaries. Furthermore, the views expressed in this publication do not necessarily reflect those of IUCN, Cardiff University or WWF International.

This publication has been made possible in large part by funding from WWF International, Cardiff University and IUCN.

Published by: IUCN, Gland, Switzerland, and Cambridge, UK and WWF International, Gland, Switzerland.

Copyright: (C) 2000 International Union for Conservation of Nature and Natural Resources

Reproduction of this publication for educational or other non-commercial purposes is authorized without prior written permission from the copyright holder provided the source is fully acknowledged.

Reproduction of this publication for resale or other commercial purposes is prohibited without prior written permission of the copyright holders.

Citation: Beltrán, J. (Ed.) (2000). Indigenous and Traditional Peoples and Protected Areas: Principles, Guidelines and Case Studies. IUCN, Gland, Switzerland and Cambridge, UK and WWF International, Gland, Switzerland. xi + $133 \mathrm{pp}$.

ISBN: $\quad 2-8317-0547-9$

Cover design by: IUCN Publications Services Unit

Cover photos: Front cover photo: Buddhist shrine and Tamserka Mt., Sagarmatha National Park, Nepal: WWF/Jim Thorsell/IUCN.

Back cover photos: Karen Hill tribes living in balance with nature, buffer zone, Huay Kha Khaeng Wildlife Sanctuary, Thailand: WWF/Hartmut Jungius/WWF; Han Chinese, Xishuangbanna, China: WWF/Charles Santiapillai; Juniperus procera, Amhara shepherd at the foot of an African cedar, Ethiopia: Michael Gunther/WWF/BIOS; Dai women having their bath in river, Xishuangbanna, China: WWF/Charles Santiapillai.

Layout by: $\quad$ IUCN Publications Services Unit

Produced by: IUCN Publications Services Unit

Printed by: $\quad$ Page Bros, Norwich, UK

Available from: IUCN Publications Services Unit

219c Huntingdon Road, Cambridge CB3 0DL,

United Kingdom

Tel: ++44 1223277894

Fax: ++44 1223277175

E-mail:info@books.iucn.org

www: http://www.iucn.org

A catalogue of IUCN publications is also available 


\section{Table of Contents}

Foreword vii

Executive Summary $\quad$ ix

\section{PART A}

Principles and guidelines for indigenous/traditional peoples and protected areas

Introduction

Principles and guidelines for indigenous/traditional peoples and protected areas

Annex 1

Annex 2

Annex 3

\section{PART B}

Case studies

$\begin{array}{lll}\text { Case studies Introduction } & 21\end{array}$

Case study 1 Kaa-Iya del Gran Chaco National Park and Integrated Management Natural Area, Bolivia

Case study 2 Cayos Miskitos and Franja Costera Marine Biological Reserve, Nicaragua

Case study 3 Sarstoon-Temash National Park, Belize 51

Case study 4 Wood Buffalo National Park, Canada 59

$\begin{array}{lll}\text { Case study } 5 & \text { The Lapponian Area, Sweden } & 69\end{array}$

Case study 6 Simen Mountain National Park, Ethiopia 77

Case study 7 Sagarmatha (Mt. Everest) National Park, Nepal 87

Case study 8 Doi Inthanon National Park, Thailand 97

$\begin{array}{lll}\text { Case study } 9 \text { Xishuangbanna Nature Reserve, China } & 105\end{array}$

Case study 10 Kytalyk Resource Reserve, Russian Federation 113

$\begin{array}{ll}\text { Case study } 11 \text { Kakadu National Park, Australia } & 123\end{array}$ 
Digitized by the Internet Archive in 2010 with funding from UNEP-WCMC, Cambridge 


\section{Foreword}

These principles, guidelines and case studies respond to WCC Resolution 1.53 on Indigenous Peoples and Protected Areas, adopted at the IUCN World Conservation Congress in Montreal, October, 1996, which

"requests the Director General, the Secretariat and technical programmes, Commissions, members, and Councillors of IUCN, within available resources, to endorse, support, participate in and advocate the development and implementation of a clear policy in relation to protected areas established in indigenous lands and territories". (for full text, see Annex 1 in Part A).

Resolution 1.53 is based on recommendations from the IV World Congress on National Parks and Protected Areas (Caracas, Venezuela, 1992), calling for the development of policies for protected areas that safeguard the interests of indigenous peoples, and take into account customary resource practices and traditional land tenure systems.

While the process of developing this document was accelerated after the resolution from Montreal, work began in 1995 between the IUCN Co-ordinator for Indigenous Peoples, the Programme on Protected Areas, and the World Commission on Protected Areas (WCPA). In parallel, WWF had been developing their own ideas, building on a series of regional and national workshops with indigenous peoples' organisations. Since many of the same issues emerged in both the WWF and IUCN consultations on this subject, it was decided to work together in developing a common position. The principles and guidelines were adopted by IUCN and WWF during 1999. They are presented as Part $\mathbf{A}$ of this publication.

In order to fill out this advice, and demonstrate the many ways in which indigenous peoples and protected areas interact in practice, a set of eleven case studies was prepared at the request of IUCN by the UNEP-World Conservation Monitoring Centre. Substantial support for this work was offered by WWF International, who contributed information and draft texts for several case studies. The results of this work are presented in Part B.

Adrian Phillips 


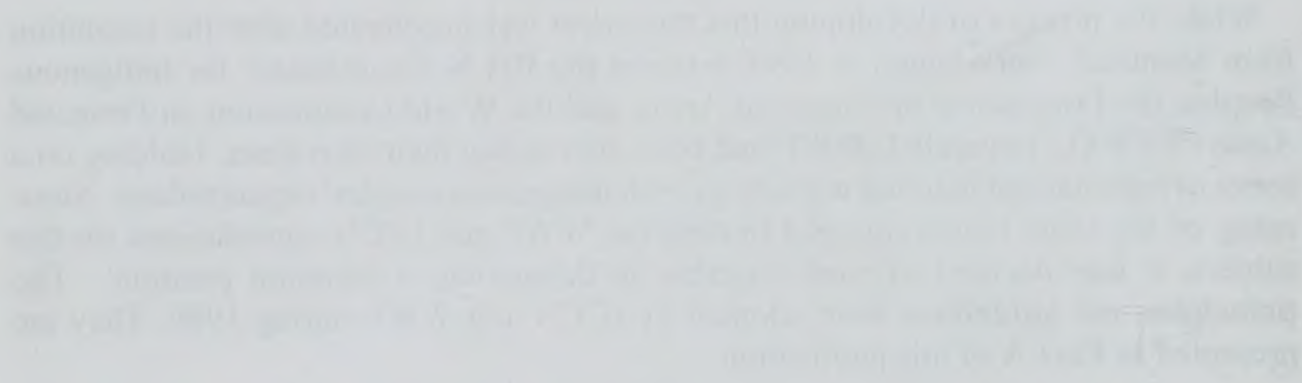

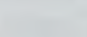

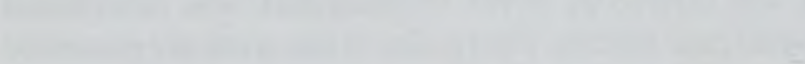
- 


\section{Executive Summary}

It is sometimes assumed that protected areas must be in conflict with the rights and traditions of indigenous and other traditional peoples on their terrestrial, coastal/marine, or freshwater domains. In reality, where indigenous and traditional peoples are interested in the conservation and traditional use of their lands, territories, waters, coastal seas and other resources, and their fundamental human rights are accorded, conflicts need not arise between those peoples' rights and interests, and protected area objectives.

In line with current understanding of the concept of sustainable development, as well as with several international agreements and dispositions, IUCN/WCPA and WWF have recognised that:

protected areas will survive only if they are seen to be of value, in the widest sense, to the nation as a whole and to local people in particular;

* the rights of indigenous and other traditional peoples inhabiting protected areas must be respected by promoting and allowing full participation in co-management of resources, and in a way that would not affect or undermine the objectives for the protected area as set out in its management plan;

2 knowledge, innovations and practices of indigenous and other traditional peoples have much to contribute to the management of protected areas;

8 governments and protected area managers should incorporate customary and indigenous tenure and resource use, and control systems, as a means of enhancing biodiversity conservation.

Based on the advice in the protected areas management categories, on estaolished WWF and IUCN policies on indigenous peoples and conservation, and on conclusions and recommendations of the IV World Congress on National Parks and Protected Areas, the two organisations, WWF and IUCN/WCPA, have adopted principles and guidelines concerning indigenous rights and knowledge systems, consultation processes, agreements between conservation institutions, decentralisation, local participation, transparency, accountability, sharing benefits and international responsibility. The five principles are as follows:

\section{Principle 1}

Indigenous and other traditional peoples have long associations with nature and a deep understanding of it. Often they have made significant contributions to the maintenance of many of the earth's most fragile ecosystems, through their traditional sustainable resource use practices and culture-based respect for nature. Therefore, there should he no inherent conflict between the objectives of protected areas and the existence, within and around their borders, of indigenous and other traditional peoples. Moreover, they should be recognised as rightful, equal partners in the development and implementation of conservation strategies that affect their lands, territories, waters, coastal seas, and other resources, and in particular in the establishment and management of protected areas. 


\section{Principle 2}

Agreements drawn up between conservation institutions, including protected area management agencies, and indigenous and other traditional peoples for the establishment and management of protected areas affecting their lands, territories, waters, coastal seas and other resources should be based on full respect for the rights of indigenous and other traditional peoples to traditional, sustainable use of their lands, territories, waters, coastal seas and other resources. At the same time, such agreements should be based on the recognition by indigenous and other traditional peoples of their responsibility to consene biodiversity, ecological integrity and natural resources harboured in those protected areas.

\section{Principle 3}

The principles of decentralisation, participation, transparency and accountability should be taken into account in all matters pertaining to the mutual interests of protected areas and indigenous and other traditional peoples.

\section{Principle 4}

Indigenous and other traditional peoples should be able to share fully and equitably in the benefits associated with protected areas, with due recognition to the rights of other legitimate stakeholders.

\section{Principle 5}

The rights of indigenous and other traditional peoples in connection with protected areas are often an international responsibility, since many of the lands, territories, waters, coastal seas and other resources which they own or otherwise occupy or use cross national boundaries, as indeed do many of the ecosystems in need of protection.

These five principles and the 22 guidelines associated with them provide a basis upon which to develop partnerships between indigenous and other traditional peoples and protected area planners and managers. They are set out in Part A. It is expected that this will greatly facilitate the creation and management of protected areas which overlap with ancestral indigenous and other traditional peoples' areas, and/or include indigenous and local communities traditionally using their resources.

Part B consists of 11 case studies demonstrating experience around the world in natural resources management within protected areas which overlap with indigenous and other traditional peoples' lands, territories or areas have been prepared. They are:

Kaa-Iya del Gran Chaco National Park and Integrated Management Natural Area (Bolivia);

Cayos Miskitos and Franja Costera Marine Biological Reserve (Nicaragua);

Sarstoon-Temash National Park (Belize);

Wood Buffalo National Park (Canada);

the Lapponian Area (Sweden);

Simen Mountain National Park (Ethiopia);

Sagarmatha (Mt. Everest) National Park (Nepal);

Doi Inthanon National Park (Thailand); 
Xishuangbanna Nature Reserve (China);

I Kytalyk Resource Reserve (Russian Federation); and

2 Kakadu National Park (Australia).

These case studies were chosen after wide review of the information about the interactions between groups of indigenous peoples and the national or local authorities responsible for managing protected areas in each country. Most case studies show where co-management is taking place, or where legal or other formal mechanisms have been set up to promote co-management. A few, however, illustrate situations where the relationships between indigenous peoples and conservation authorities have not gone well, with negative impacts on protected area performance. They provide examples and information that can be used to develop and strengthen partnerships for protected area management.

Major lessons learnt from them are as follows:

1. Where indigenous peoples" participation in management has taken place early in the planning process, there have been benefits for both the indigenous peoples and the management authorities;

2. The wider the participation of the indigenous peoples in all aspects of management, the less likely it is that conflicts will arise;

3. In those areas in which some type of co-management is already taking place, the challenge is how to reiniorce and extend the mechanisms. Where indigenous peoples do not at present participate, the challenge is how to make it happen.

The main conclusions are the following:

Indigenous and other traditional peoples are indeed actively interacting with protected areas around the world. The case studies presented here show only a small sample of these interactions.

Most protected areas described here were proclaimed without the expressed consent of the people who previously inhabited lands or seas in the region. As a result, protected area authorities have been making decisions about species or ecosystems contained in these areas without the full involvement of the key stakeholders.

Fortunately this situation is now changing. This is partly because a more general acceptance of indigenous peoples' rights is emerging; and partly because it is now widely recognised that the involvement of indigenous peoples is essential to ensure long-term sustainability of the protected areas in which they live or have an interest.

However, in reality the involvement of indigenous and traditional peoples in the planning and decision-making processes, and empowerment of local groups, often fall short of the ideal. One way to develop co-management of protected areas where it has been slow to take root could be through informal consultation and discussions between government agencies and indigenous peoples communities, perhaps facilitated by international organisations. 



\section{PART A}

\section{Principles and guidelines for indigenous/traditional peoples and protected areas}





\section{Introduction}

IUCN defines a protected area as:

An area of land andlor sea especially dedicated to the protection and maintenance of biological diversity; and of natural and associated cultural resources, and managed through legal or other effective means [emphasis added]. (IUCN, 1994(a)).

This reference to "associated cultural resources" reflects a view of conservation that can accommodate the social, economic and cultural interests, values, rights and responsibilities of local communities living in and around protected areas.

It is sometimes assumed that protected areas must be in conflict with the rights and traditions of indigenous and other traditional peoples on their terrestrial, coastal/marine, or freshwater domains. In reality, where indigenous peoples are interested in the conservation and traditional use of their lands, territories, waters, coastal seas and other resources, and their fundamental human rights are accorded, conflicts need not arise between those peoples' rights and interests, and protected area objectives. Moreover, formal protected areas can provide a means to recognise and guarantee the efforts of many communities of indigenous and other traditional peoples who have long protected certain areas, such as sacred groves and mountains, through their own cultures. Sometimes, indeed, these communities now require outside support to defend such valued places against external threats - support which protected areas can provide.

Specifically, what many indigenous and other traditional peoples' organisations have demanded is that protected areas established on their terrestrial, coastal/marine and freshwater domains:

effectively protect those domains, as well as the people and cultures they contain, from external threats, and in particular reinforce traditionally protected areas;

recognise indigenous and other traditional peoples' rights to their lands, territories, waters, coastal seas, and other resources;

recognise their rights to control and co-manage these resources within protected areas;

allow participation of traditional institutions in co-management arrangements within their terrestrial, coastal/marine and freshwater domains;

recognise the rights of indigenous and other traditional peoples to determine their own development priorities - as long as these priorities are compatible with protected area objectives;

be declared only at their initiative, and/or with their free and prior informed consent;

incorporate sustainable use of natural resources using methods that maintain the integrity of the ecosystem and that have been used traditionally by indigenous peoples. 
These claims can be reconciled with the objectives of protected areas, as defined by IUCN, particularly those under Categories V and VI (see Annex 2). However, they require that governments, that have not already done so, put in place policies and strategies to help establish effective, sustainable partnerships between conservation agencies and indigenous and other traditional peoples. Indigenous peoples should participate in the co-management of their traditional land and territories and have equal opportunities to members of other groups, as well as other stakeholders interested in the conservation of that area. All decisions passed by co-management organisations should ensure that the maintenance of the ecological integrity of protected areas remains the highest priority. Partnerships between indigenous peoples and protected area management agencies should be based on a sound understanding of the social, economic, and cultural needs of individuals, peoples, and nations, as well as of the complex interplay of factors driving resource-use patterns.

In line with current understanding of the concept of sustainable development, as well as with the Convention on Biological Diversity, ILO Convention 169 (see Annex 3), Agenda 21, and the Rio Declaration on Environment and Development, WWF and IUCN recognise that:

protected areas will survive only if they are seen to be of value, in the widest sense, to the nation as a whole and to local people in particular;

the territorial and resource rights of indigenous and other traditional peoples inhabiting protected areas must be respected by promoting and allowing full participation in co-management of resources, and in a way that would not affect or undermine the objectives for the protected area as set out in its management plan;

knowledge, innovations and practices of indigenous and other traditional peoples have much to contribute to the management of protected areas;

governments and protected area managers should incorporate customary and indigenous tenure and resource use, and control systems, as a means of enhancing biodiversity conservation.

In WCC resolution 1.53, IUCN has acknowledged that indigenous peoples have the right "to participate effectively in the management of the protected areas established on their lands or territories", and therefore agreements should be reached with them "prior to the establishment of protected areas in their lands or territories". This resolution also requests all components of IUCN to "endorse, support, participate in and advocate the development and implementation of a clear policy in relation to protected areas established in indigenous lands and territories". This action is to be based on the recognition of land/territorial and resource rights, the necessity for prior agreement on the establishment of new protected areas on their lands or territories, and rights to effective participation in protected area management (the full text of the resolution is at Annex 1).

The IUCN system of protected area management categories was first published in 1978 (IUCN, 1978). Following comprehensive review, including through a workshop at the IVth World Congress on National Parks and Protected Areas (Caracas, Venezuela, 1992), a revised version of the guidelines was adopted, by Resolution 19.4, at the IUCN General Assembly in Buenos Aires in 1994 (IUCN, 1994b), and published later that year (IUCN, 1994(a), see Annex 2). Most of these revised categories explicitly recognise that indigenous and local communities may occupy and/or use such areas. The system as a whole has the potential to accommodate a range of models of protected areas, according 
to the degree of human intervention, in a way that both indigenous and other traditional peoples' rights and conservation objectives can be respected.

In its Statement of Principles on Indigenous Peoples and Conservation, WWF declares that:

"WWF will not promote or support, and may actively oppose, interventions which have not received the prior, free and informed consent of affected indigenous communities, and/or would adversely impact - directly or indirectly - on the environment of indigenous peoples' territories, and/or would affect their rights. This includes activities such as:

5 economic or other development activities;

ฐnatural resources exploitation;

$\square$ commercially oriented or academic research;

च resettlement of indigenous communities;

* creation of protected areas or imposition of restrictions on subsistence resource use;

colonisation within indigenous territories".

Based on the advice in the protected areas management categories, on established WWF and IUCN policies on indigenous peoples and conservation, and on conclusions and recommendations of the IV World Congress on National Parks and Protected Areas, the two organisations, WWF and IUCN/WCPA. have adopted the following Principles and Guidelines on Indigenous/Traditional Peoples and Protected Areas. These provide a basis upon which to develop partnerships between indigenous and other traditional peoples and protected area planners and managers. This will facilitate the establishment and management of protected areas which overlap with ancestral indigenous and other traditional peoples' areas, and/or include indigenous and local communities traditionally using their resources.

In addition, case studies have been prepared (Part B) which demonstrate experience around the world in natural resource management within protected areas which overiap with indigenous and other traditional peoples' lands, territories or areas. The case studies are intended to provide examples and information that can be used to develop and strengthen partnerships for protected area management.

The principles and guidelines proposed in this document should be considered as a framework aimed at providing guidance, not as a blueprint. Thus, they should be adapted to the particular situation, legislation, and policies of each country, and used together with other complementary approaches and tools, to ensure effective management of protected areas in partnership with indigenous and other traditional peoples living within or around their borders.

The definition of indigenous peoples used in this document is that adopted by the ILO (see Annex 3). 



\section{Principles and guidelines on protected areas and indigenous/ traditional peoples}

\section{Principle 1}

Indigenous and other traditional peoples have long associations with nature and a deep understanding of it. Often they have made significant contributions to the maintenance of many of the earth's most fragile ecosystems, through their traditional sustainable resource use practices and culture-based respect for nature. Therefore, there should be no inherent conflict between the objectives of protected areas and the existence, within and around their borders, of indigenous and other traditional peoples. Moreover, they should be recognised as rightful, equal partners in the development and implementation of conservation strategies that affect their lands, territories, waters, coastal seas, and other resources, and in particular in the establishment and managenent of protected areas.

\section{Guidelines}

1.1 In cases where protected areas overlap with indigenous and other traditional peoples' lands, territories, waters, coastal seas, and other resources, agreements should be sought between the respective communities involved and conservation agencies, without prejudice to any other existing treaty or legal arrangement involving indigenous and other traditional peopies. Such agreements should: establish common objectives and commitments to the conservation of protected areas; define responsibilities for conservation and sustainable use of biodiversity and natural resources contained in them; and be the basis for management objectives, standards, regulations, etc. Agreements should be streamlined so that they create the minimal bureaucracy necessary to ensure efficient co-management of resources;

1.2 Development of such agreements should be framed within national protected area objectives, plans and policies, and within the framework of national laws and regulations. This is necessary to ensure that such agreements are consistent with national objectives and obligations towards the protection of the natural and cultural heritage of a given country, including any relevant international obligations (e.g. under international conservation agreements);

1.3 The formulation of protected area management plans should actively incorporate indigenous and traditional knowledge, experiences and practices for ecologically sustainable use of local resources, together with contributions and tools derived from other knowledge systems, including those of the natural and social sciences: 
1.4 The mechanisms for monitoring indigenous and other traditional peoples' terrestrial, coastal/marine and freshwater zones within protected areas should also integrate traditional knowledge and practices relevant to biodiversity conservation and sustainable use, and tools derived through other knowledge systems;

1.5 As far as possible, there should be harmony between national protected area legislation and the system of international protected area categories advocated by IUCN (Annex 3). Being fully compatible with these principles and guidelines, this system offers useful options for the interests of indigenous and other traditional peoples, and for resolving disputes concerning protected areas.

\section{Principle 2}

Agreements drawn up between conservation institutions, including protected area management agencies, and indigenous and other traditional peoples for the establishment and management of protected areas affecting their lands, territories, waters, coastal seas and other resources should be based on full respect for the rights of indigenous and other traditional peoples to traditional, sustainable use of their lands, territories, waters, coastal seas and other resources. At the same time, such agreements should be based on the recognition by indigenous and other traditional peoples of their responsibility to conserve biodiversity, ecological integrity and natural resources harboured in those protected areas.

\section{Guidelines}

2.1 Agreements between representatives of the respective communities and conservation agencies for the establishment and management of protected areas should contribute to securing indigenous and other traditional peoples' rights, including the right to the full and effective protection of their areas, resources and communities. At the same time, such agreements should define the responsibilities of both parties to conserve and sustainably manage the resources of those communities, and which protected areas are intended to safeguard;

2.2 As part of the development of such agreements, the following indigenous and other traditional communities' rights should be respected in relation to the lands, territories, waters, coastal seas and other resources which they traditionally own or otherwise occupy or use, and which fall within protected areas:

a) rights with regard to sustainable, traditional use of their lands, territories, waters, coastal seas and other resources that fall within protected areas,

b) rights to participate in controlling and managing their lands, territories, waters, coastal seas and other resources, in compliance with agreed management regulations and plans,

c) rights to participate in deciding on issues, such as technologies and management systems, affecting their lands, territories, waters, coastal seas and other resources, subject to agreed management regulations and plans,

d) rights to participate in determining priorities and strategies for the development or use of their lands, territories, waters, coastal seas and other resources, in the context of agreed management regulations and plans, 
e) rights to use their own traditional institutions and authorities to co-manage their terrestrial, coastal/marine and freshwater areas, as well as to defend them from external threats, subject to agreements with the agencies in charge of national protected area systems,

f) rights to require that States obtain the free and informed consent of the respective communities, prior to the approval of any project affecting their lands, territories, waters, coastal seas or other resources,

g) rights to improve the quality of their lives, and to benefit directly and equitably from the conservation and ecologically sustainable use of natural resources contained in their terrestrial, coastal/marine and freshwater areas,

h) collective rights to maintain and enjoy their cultural and intellectual heritage, particularly the cultural patrimony contained in protected areas, and the knowledge related to biodiversity and natural resource management,

i) rights not to be removed from the zones they have traditionally occupied within protected areas. Where their relocation is considered necessary as an exceptional measure, it should take place only with the free and prior, informed consent of the indigenous and other traditional peoples affected, and with appropriate compensation;

2.3 The establishment of new protected areas on indigenous and other traditional peoples' terrestrial, coastal/marine and freshwater domains should be based on the legal recognition of collective rights of communities living within them to the lands, territories, waters, coastal seas and other resources they traditionally own or otherwise occupy or use;

2.4 However, since legal recognition of rights does not fall within the mandate of protected area managers, managers should promote interim arrangements with the respective indigenous and other traditional communities. Such arrangements, while fully respecting the rights and claims of such peoples and communities, and not interfering with the respective legal processes underway to determine these, should ensure that protection measures are put quickly into place, based where needed on management or co-management agreements;

2.5 In cases where indigenous and other traditional peoples' rights within protected areas are not yet recognised by a government, and until the process leading towards such recognition is completed, the concerned communities should still be guaranteed access to the resources existing in their terrestrial, coastal/marine and freshwater areas, insofar as they are necessary for their livelihoods. Any access restrictions should be agreed on with the communities concerned, and appropriate compensation should be given in cases where such restrictions are considered necessary by all parties, to ensure appropriate conservation of the resources contained within the protected area.

\section{Principle 3}

The principles of decentralisation, participation, transparency and accountability should be taken into account in all matters pertaining to the mutual interests of protected areas and indigenous and other traditional peoples. 


\section{Guidelines}

3.1 Within indigenous and other traditional peoples' terrestrial, coastal/marine and freshwater domains included in protected areas, authorities representing indigenous and other traditional peoples, as well as indigenous and other traditional peoples' decision-making mechanisms and processes, should be recognised and respected, within the framework of national legislation and policies. To this end, the legal and institutional structure of protected area systems should be reformed as appropriate, so as to accommodate these institutions and decision-making mechanisms and processes in a co-management framework;

3.2 Management of protected areas should occur through a formal mechanism, which recognises both rights and responsibilities, for example by management and co-management agreements and by jointly devised management plans. Indigenous and traditional institutions which co-manage those areas, as well as the respective local, provincial, or national protected area agencies, should be mutually accountable for the fulfilment of the agreed objectives and plans;

3.3 Mutual assessment of performance should be encouraged through regular monitoring and transparent reporting by both protected area agencies and indigenous and other traditional peoples' organisations;

3.4 New protected areas within indigenous and other traditional peoples' terrestrial, coastal/marine and freshwater domains should be established only on the basis of voluntary declaration, and/or on agreement between representatives of the respective communities and the local, provincial, or national government;

3.5 The process of establishing new protected areas on indigenous and other traditional peoples' terrestrial, coastal/marine or freshwater domains should fulfil the following procedures:

a) collaborative research with the indigenous and other traditional peoples concerned for the identification of the features that make the area suitable for protection,

b) initiation of formal processes to give legal recognition to indigenous and other traditional peoples' land and resource rights, if such legal recognition does not yet exist,

c) agreement on the designation and management of the protected area, involving the respective organisations and communities, relevant government agencies, non-governmental conservation agencies, and other stakeholders, including arrangements which will ensure mutual accountability,

d) collaborative development of a management plan between the respective government and non-governmental conservation bodies and the communities concerned;

3.6 In developing solid partnerships with indigenous and other traditional peoples for protected area management, government agencies and non-governmental conservation organisations should inter alia:

promote open dialogue with indigenous and other traditional peoples' organisations and communities, based on these and other appropriate principles and guidelines, 
promote and support the necessary legal and policy changes,

develop conflict-resolution processes whenever necessary, and

encourage and develop capacity-building actions for indigenous and other traditional peoples' organisations and communities;

3.7 Governments and non-governmental organisations should provide resources to develop campaigns directed at the national population, aimed at increasing public awareness about indigenous and other traditional peoples' cultural and spiritual values and rights. This is to help ensure that the society as a whole recognises the rights of indigenous and other traditional peoples to exercise management of their terrestrial, coastal/marine and freshwater domains, and understands the environmental benefits of respecting these rights.

\section{Principle 4}

Indigenous and other traditional peoples should be able to share fully and equitably in the benefits associated with protected areas, with due recognition to the rights of other legitimate stakeholders.

\section{Guidelines}

4.1 In order for co-management agreements between indigenous and other traditional peoples and protected area managers to be effective, governments should guarantee the provision of such benefits as:

effective defence of territories against external threats,

support and legal protection of territories,

consolidation of territories, including their demarcation,

technical, financial and political support for indigenous and other traditional peoples' own management activities, and

sustained capacity-building actions and processes for indigenous and local communities, in order to help them to manage their areas and resources effectively;

4.2 Governments should design and implement economic and other incentive systems for conservation and sustainable use of indigenous and other traditional peoples' terrestrial, coastal/marine and freshwater domains contained in protected areas;

4.3 Governments should ensure that indigenous and other traditional peoples benefit fully from the economic and employment opportunities associated with the existence of protected areas, e.g. from income generated by tourism, and by employment in protected area management.

\section{Principle 5}

The rights of indigenous and other traditional peoples in connection with protected areas are often an international responsibility, since many of the lands, territories, 
waters, coastal seas and other resources which they own or otherwise occupy or use cross national boundaries, as indeed do many of the ecosystems in need of protection.

\section{Guidelines}

5.1 Where indigenous and other traditional peoples' lands, territories, waters, coastal seas, and other resources are located within trans-frontier protected areas, governments should adopt instruments to guarantee that protected area management respects and supports the integrity of the respective indigenous and local communities;

5.2 In order to guarantee both conservation objectives and indigenous and other traditional peoples' rights in areas which have been subject to armed conflict or dispute, governments (singly or in partnership with their neighbours in the region), and other relevant institutions, should develop agreements and measures to ensure that indigenous and other traditional peoples' terrestrial, coastal/marine and freshwater domains within protected areas are treated as zones of peace and reconciliation. 


\section{Annex 1}

\section{IUCN World Conservation Congress (WCC) \\ Resolution 1.53 - Indigenous Peoples and Protected Areas (October 1996)}

RECALLING that some protected areas have been established on indigenous lands and territories without the consent and participation of the affected people;

CONSIDERING the terms of ILO Convention No. 169 and those of the Convention on Biological Diversity, regarding the role of indigenous peoples with respect to the management, use and conservation of biodiversity;

CONSIDERING the recommendations and guidelines established in Agenda 21;

CONSIDERING the emphasis placed in Caring for the Earth on the role of indigenous peoples in sustainable development and their rights in the management of natural resources;

CONSIDERING the recommendations of the IVth World Congress on National Parks and Protected Areas, calling for the development of policies for protected areas which safeguard the interests of indigenous peoples;

RECOGNIZING that several governments have already adopted policies and measures to fully incorporate the rights and interests of indigenous peoples in the establishment and management of protected areas within their lands and territories;

The World Conservation Congress at its 1st Session in Montreal, Canada, 14-23 October 1996:

1. REQUESTS the Director General, the Secretariat and technical programmes, Commissions, members and Councillors of IUCN, within available resources, to endorse, support, participate in and advocate the development and implementation of a clear policy in relation to protected areas established in indigenous lands and territories, based on the following principles:

a) recognition of the rights of indigenous peoples with regard to their lands or territories and resources that fall within protected areas;

b) recognition of the necessity of reaching agreements with indigenous peoples prior to the establishment of protected areas in their lands or territories;

c) recognition of the rights of the indigenous peoples concerned to participate effectively in the management of the protected areas established on their lands or territories, and to be consulted on the adoption of any decision that affects their rights and interests over those lands or territories. 
2. URGES all IUCN members to establish appropriate mechanisms at the national level, for the development and implementation of policies on protected areas and indigenous peoples that are consistent with these principles.

3. REQUESTS the World Commission on Protected Areas to establish closer links with indigenous peoples' organizations, with a view to incorporating the rights and interests of indigenous peoples in the application of the IUCN Protected Area Management Categories.

4. REQUESTS the Director General, within available resources, to incorporate in IUCN's work on protected areas and natural heritage, specific actions aimed at ensuring the further development and implementation of appropriate policies based on these principles. 


\section{Annex 2}

\section{IUCN System of Protected Area Management Categories (1994)}

The six management categories are defined by the primary management objective, as follows:

I. Protected area managed mainly for I(a) science or I(b) wilderness protection. Areas of land and/or sea possessing some outstanding or representative ecosystems, geological or physiological features and/or species, available primarily for scientific research and/or environmental monitoring; or large areas of unmodified or slightly modified land, and/or sea, retaining their natural character and influence, without permanent or significant habitation, which are protected and managed so as to preserve their natural condition. (Strict Nature Reserve/ Wilderness Area).

II. Protected area managed mainly for ecosystem conservation and recreation. Natural areas of land and/or sea, designated to (a) protect the ecological integrity of one or more ecosystems for this and future generations, (b) exclude exploitation or occupation inimical to the purposes of designation of the area and (c) provide a foundation for spiritual, scientific, educational, recreational and visitor opportunities, all of which must be environmentally and culturally compatible. (National Park).

III. Protected area managed mainly for conservation of specific features. Areas containing one, or more, specific natural or natural/cultural feature which is of outstanding or unique value because of its inherent rarity, representaive or aesthetic qualities or cultural significance. (Natural Monument).

IV. Protected area managed mainly for conservation through management intervention. Areas of land and/or sea subject to active intervention for management purposes so as to ensure the maintenance of habitats and/or to meet the requirements of specific species. (Habitat/Species Management Area).

V. Protected area managed mainly for landscape/seascape conservation and recreation. Areas of land, with coast and sea as appropriate, where the interaction of people and nature over time has produced an area of distinct character with significant aesthetic, cultural and/or ecological value, and often with high biological diversity. Safeguarding the integrity of this traditional interaction is vital to the protection, maintenance and evolution of such an area. (Protected Landscape/ Seascape).

VI. Protected area managed mainly for the sustainable use of natural ecosystems. Areas containing predominantly unmodified natural systems, managed to ensure long-term protection and maintenance of biological diversity, while providing at the same time a sustainable flow of natural products and services to meet community needs. (Managed Resource Protected Area).

Source: IUCN, 1994(a) 



\section{Annex 3}

\section{ILO Convention 169}

\section{Definition of Indigenous and Tribal Peoples}

1. This Convention applies to:

a) tribal peoples in independent countries whose social, cultural, and economic conditions distinguish them from other sections of the national community, and whose status is regulated wholly or partially by their own customs or traditions or by special laws or regulations;

b) peoples in independent countries who are regarded as indigenous on account of their descent from the populations which inhabited the country, or a geographical region to which the country belongs, at the time of conquest or colonisation or the establishment of present state boundaries and who, irrespective of their legal status, retain some or all of their own social, economic, cultural and political iustitutions.

2. Self-identification as indigenous or tribal shall be regarded as a fundamental criterion for determining the groups to which the provisions of this Convention apply (Article 1).

\section{References}

IUCN (1978). Categories, objectives and criteria for protected areas. IUCN, Gland, Switzerland. 26pp.

IUCN (1993). Parks for Life: Report of the IVth World Congress on National Parks and Protected Areas. IUCN, Gland, Switzerland. viii + 260pp.

IUCN (1994a). Guidelines for Protected Area Management Categories. CNPPA with the assistance of WCMC. IUCN, Gland, Switzerland and Cambridge, UK. $x+261 \mathrm{pp}$.

IUCN (1994b). IUCN 19th General Assembly: Resolutions and Recommendations. IUCN, Gland, Switzerland. 80pp.

IUCN (1997). World Conservation Congress: Resolutions and Recommendations. IUCN, Gland, Switzerland. 95pp. 



\section{PART B}

Case studies 



\section{Case studies}

\section{Introduction}

It is estimated that there are 5,000 to 6,000 distinct groups of indigenous and traditional peoples living in more than 70 countries. Their number total about 250 million, which is roughly four to five percent of the world's population (Cohen, 1999). Most indigenous peoples rely heavily on natural resources, and most live in remote areas. Because remote and pristine areas are often significantly rich in biodiversity, much of the land that indigenous peoples occupy has been designated as national parks or other types of protected areas (Nepal, 1999).

Efficient use of natural resources is important to the survival of indigenous groups. In the past 15 years, indigenous and traditional peoples have become increasingly important players in the ownership and management of relatively undisturbed landscapes (Redford and Mansour, 1996). The 11 case studies presented here demonstrate experience around the world in natural resource management within protected areas overlapping with indigenous peoples' lands or territories (Map1). They are:

Kaa-Iya del Gran Chaco National Park and Integrated Management Natural Area (KIGC, Bolivia);

Cayos Miskitos and Franja Costera Marine Biological Reserve (RBMCM, Nicaragua);

Sarstoon-Temash National Park (STNP, Belize);

* Wood Buffalo National Park (WBNP, Canada);

* the Lapponian Area (LAPP, Sweden);

* Simen Mountain National Park (SMNP, Ethiopia);

- Sagarmatha (Mt. Everest) National Park (SNP, Nepal);

Doi Inthanon National Park (DINP, Thailand);

Xishuangbanna Nature Reserve (XNR, China);

Kytalyk Resource Reserve (KRR, Russian Federation); and

Kakadu National Park (KNP, Australia).

These case studies were chosen after wide review of the information about the interactions between groups of indigenous peoples and the national or local authorities responsible for managing protected areas in each country. Most case studies show where co-management is taking place, or where legal or other formal mechanisms have been set up to promote co-management. A few, however, illustrate situations where the relationships between indigenous peoples and conservation authorities have not gone well, with negative impacts on protected area performance.

Five case studies (KIGC, RBMCM, LAPP, KRR and KNP) were prepared by UNEP-WCMC following a search of published and grey literature on protected areas 
and indigenous/traditional peoples' issues for each of the selected sites. The information gathered through this search is set out as follows:

Background information: this section gives details about the protected area: its location, principal biogeographic characteristics, fauna and flora, date of creation, type of legal designation, assigned Protected Area Management Category (according to IUCN, 1994), organisation responsible for the area's administration and management, and prevailing land ownership regime;

Indigenous/Traditional people(s): this section identifies the indigenous peoples who have a stake in the management of the protected area, and reviews their origins, characteristics (demographic, linguistic, etc.) and relevant aspects of the history of the country or region where they live;

Involvement of the indigenous peoples group(s) in the management and administration of the protected area: this section provides an analysis of the institutional framework for the creation and management of protected areas in the country. It includes details of: any mechanism to promote the participation of indigenous peoples in these processes; any example where indigenous peoples have been called upon to play roles and activities in the implementation of specific management and/or administrative actions; and how benefits originating from protected areas are shared with indigenous peoples;

Traditional knowledge and practices: this section describes how indigenous peoples' activities affect the protected area, such as the collection and use of medicinal plants, traditional agriculture, migrations and population movements, hunting, and sacred sites;

Critical evaluation of lessons learnt: this section describes evidence of the positive or negative impact of the interaction between the indigenous peoples and the protected area. Points include: conflicts that were solved as a result of the participation of indigenous peoples in the management of the protected area; examples of management actions undertaken jointly between the managing agency and indigenous peoples (e.g. surveillance, tourism, control of poaching or illegal logging); and any unresolved issues that complicate the collaborative management of the protected area;

Major challenges or directions for the future: this section provides some initial recommendations on how to maintain relationships between the protected area and any indigenous peoples interacting with it, and how to improve this interaction if possible.

The other six case studies (STNP, WBNP, SMNP, SNP, DINP and XNR) were prepared by external consultants on behalf of WWF-International's People and Conservation Unit. Originally these had a slightly different format, although some modifications to the original text were introduced to harmonise the way in which information is presented throughout this document.

Name of genera and families of plants are based on Mabberley (1987). Scientific nomenclature of species is based on Gorbet and Jill (1991) for mammals, Howard and Moore (1984) for birds. Frost (1985) for amphibians, Nelson (1984) for fishes. The conservation status of species follows IUCN (1996). Maps accompanying the text were prepared by Ian May, from the GIS Department of UNEP-WCMC. 


\section{Map 1 Location of the 11 case studies demonstrating existing interactions between indigenous and other traditional peoples and protected areas around the world.}

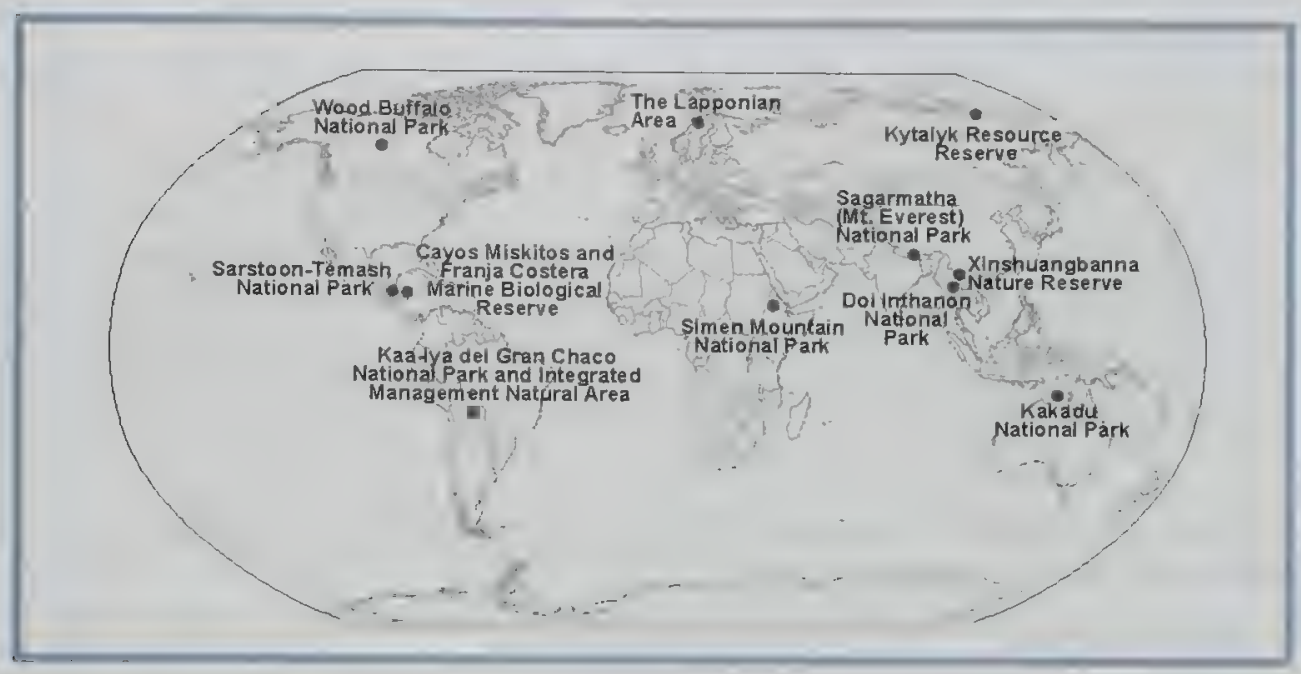

\section{Case studies: an overview}

A comparative review was undertaken of the 11 case studies. This focused on five issues: (1) general biogeographic characteristics and management types of the protected areas; (2) the overall situation of indigenous peoples within each protected area; (3) the actual indigenous peoples involvement in co-management; (4) major conflicts; and (5) lessons learnt and challenges for the future.

\section{General characteristics and management types}

Table 1 provides a summary review of the eleven protected areas with indications of their main characteristics and management types, and of the number and population of indigenous peoples groups inhabiting them.

Taken together, the selected sites cover a wide array of habitats, from exclusively coastal and marine types (RBMCM) to almost barren land well above $5,000 \mathrm{~m}$ of altitude (SNP), and from Arctic to tropical environments. The total area covered by these properties is $151,010 \mathrm{~km}^{2}$, the largest site being WBNP $\left(44,800 \mathrm{~km}^{2}\right)$ and the smallest SMNP $\left(136 \mathrm{~km}^{2}\right)$. They all have an outstanding diversity and are ecologically significant for numerous species of fauna and flora of conservation concern, for example tiger, snow leopard, Simen fox, marine turtles, and many birds and fish. Some sites comprise the breeding grounds or seas of wild or semi-domesticated species of economic value, such as reindeer, wood bison, shrimps and lobsters.

The case studies comprise designations with widely differing objectives, from strictly protected areas (IUCN Protected Area Management Categories I/II/III), to reserves in which some level of sustainable use is currently permitted (Categories IV and VI). Two sites (KIGC and LAPP) include multiple designations and management types. The present designation and managenent category of RBMCM are currently under revision and are expected to be changed in the near future. 
The age of the sites in the list of case studies vary greatly. Thus, two of the six separate protected areas in LAPP were established as early as 1909, while the others were set up in 1941, 1962 and the late 1980s. WBNP was designated in 1922. The youngest protected area in the list is KIGC, established in 1995.

Five protected areas have been included on the World Heritage List (WBNP, LAPP, SMNP, SNP and KNP) for their natural values, and two (LAPP and KNP) for natural and cultural values. SMNP has recently been put on the List of World Heritage in Danger. LAPP has additionally been awarded the Council of Europe European Diploma Type A site. XNR is part of the UNESCO Man and Biosphere Programme. Three properties contain Wetlands of International Importance (Ramsar sites) (WBNP, LAPP and KNP). Generally, land within the protected areas is publicly owned. Some form of communal land ownership prevails in scctions of RBMCM, KIGC and KNP (freehold communal land).

\section{Indigenous/Traditional peoples: their overall situation within each protected area}

More than 32 indigenous and traditional peoples, plus other minority groups, live within or near the selected protected areas. The site with the largest number of different indigenous peoples groups is XNR with more than 13 communities, whilst four sites are inhabited by only one distinctive group (RBMCM, LAPP, SNP and KRR). None of the 11 sites covers the entire territory occupied by any of the indigenous peoples.

Table 1: Analysis of the 11 case studies

\begin{tabular}{|c|c|c|c|c|c|c|}
\hline Name & Area $\left(\mathrm{km}^{2}\right)$ & $\mathrm{MC}$ & IPS & $\mathrm{CG}$ & PL & PD \\
\hline KIGC & 35,000 & $\mathrm{II} / \mathrm{VI}$ & - & 3 & 8,000 & 0.23 \\
\hline $\mathrm{RBMCM}$ & 13,000 & Ia & - & 1 & 25,000 & 1.9 \\
\hline STNP & 168 & II & - & 2 & 660 & 3.9 \\
\hline WBNP & 44,800 & II & NWHS/RS & 3 & - & - \\
\hline LAPP & 9,400 & IL/IV & $\begin{array}{l}\text { NCWHS/RS/ } \\
\text { ED }\end{array}$ & 1 & 250 & 0.03 \\
\hline SMNP & 136 & II & NWHS* & 3 & 10,000 & 73.5 \\
\hline SNP & 1,150 & II & NWHS & 1 & 3,100 & 2.7 \\
\hline DINP & 482 & II & NWHS & 2 & 4,500 & 9.3 \\
\hline XNR & 2,070 & IV & BR & $>13$ & 14,000 & 6.8 \\
\hline KRR & 25.000 & IV & - & 1 & $?$ & $?$ \\
\hline KNP & 19.804 & II & NCWHS/RS & 3 & 550 & 0.27 \\
\hline
\end{tabular}

Key:

$\mathrm{MC}=$ IUCN Protected Area Management Category

IPS = international protection status (NWHS: Natural World Heritage site; NCWHS: Natural/Cultural World Heritage site; NWHS*: Natural World Heritage in Danger; RS: Ramsar site; BR: Biosphere Reserve)

$\mathrm{CG}=$ number of distinct indigenous and other traditional peoples groups

$\mathrm{PL}=$ estimated resident human population

$\mathrm{PD}=$ population density per $\mathrm{km}^{2}$ 
No people are allowed to live in the interior of most of the selected protected areas, but human occupation is limited to specially designated sectors in some of them. However, the level of enforcement of these restrictions is generally poor, meaning that people live inside most sites "illegally". The total permanent human occupation (excluding protected area staff) ranges from nil (WBNP) to 25,000 people (RBMCM). The population density in areas where there is either legal or illegal occupation varies between 0.3 people $/ \mathrm{km}^{2}$ (KNP) and 73.5 people $/ \mathrm{km}^{2}$ (SMNP), the densities being calculated for the entire territory of each protected area.

All sites support some level of sustainable/commercial use of natural resources by the indigenous peoples or other groups. Hunting and fishing are the most common productive activities, but there is also farming, livestock raising and forestry. Husbandry practices are important in two sites (LAPP and KRR), and are conccntrated on reindeer. Tourism is by far the most prominent economic activity in SNP and important in many other sites, e.g. KNP; diving for lobster is the prevailing economic activity in RBMCM.

\section{Actual IP involvement in co-management}

The management approaches described in the case studies are of three broad kinds:

Unrestricted co-management: a comprehensive participation of indigenous peoples in protected area management programmes occurs in KIGC, RBMCM, KRR and KNP. The institutional frameworks currently in force in these countries generally provide for full participation of indigenous peoples. As a result, participation involves almost every aspect of the management process including planning and implementation of management plans and actions. Specifically, indigenous peoples have become part of management committees or of similar arrangements. Often, members of the indigenous people communities are responsible for implementing particular management measures.

Restricted co-management: a restricted involvement of indigenous peoples in management occurs in WBNP, LAPP and SNP. In these cases, co-management is limited to specific activities, such as reindeer husbandry (LAPP), management of free-roaming herds of bison (WBNP) and tourism (SNP). In XNR, the involvement of indigenous peoples in planning and management of the protected area depends on negotiations between the protected area staff and local communities. However, there are no legal or other formal mechanisms to secure this: its continuation depends entirely on the good-will of the staff.

Non-participatory management: this is the approach that clearly prevails in both SMNP and DINP. Most management decisions are taken by protected area authorities at central offices, which are located in the respective capital city. Nevertheless, there are some initial signs of decentralisation of management in SMNP.

\section{Major conflicts}

The ownership of land and sea within protected areas is the factor which causes most difficulty between indigenous peoples and conservation authorities. Even in those cases where there is better understanding and communication between the two groups (such as KIGC, RBMCM and KNP), there are still unresolved issues. In RBMCM, a law of property of the indigenous territories is about to be passed by the Nicaraguan National Assembly. The land ownership situation is even more problematic in sites with high 
human population density, and in protected areas which are receiving an influx of migrants from nearby regions that are at war, in turmoil or whose resources have already been severely depleted (e.g. SMNP).

Access to land and coastal/marine resources is the second most significant factor generating conflicts between indigenous peoples and protected area authorities. This issue has been addressed in some areas, particularly in those where indigenous peoples have been called upon to play a key role in the development and implementation of specific management actions. In XNR, it has been partially resolved by the decision of management authorities to tolerate some level of use of resources (e.g. gathering of medicinal plants) by local groups. On the other hand, the use of resources by indigenous peoples groups is still considered as unacceptable and negative for the long-term preservation of natural resources in areas such as SMNP and DINP.

Another source of conflict is the granting of concessions to commercial companies to extract land or sea resources (oil, forest, fish, lobster) from within the protected areas or from their surroundings. For example, the right-of-way of a gas pipeline passes through one section of KIGC, but the company has accepted to pay compensation to local groups. In KNP, the location of mineral lease areas is causing much debate and has almost resulted in the site's inclusion on the list of World Heritage sites in Danger. In RBMBM, the central government has failed to control the exploitation of marine resources (e.g. lobster) by commercial companies within the reserve, and the cutting of forest around it to the disadvantage of indigenous peoples.

\section{Lessons learnt and major challenges}

The most relevant lessons are these:

1. where indigenous and other traditional peoples' participation in management has taken place early in the planning process, there have been benefits for both the indigenous peoples and the management authorities (see KIGC and WBNP);

2. the wider the participation of the indigenous and other traditional peoples in all aspects of management, the less likely it is that conflicts will arise (see KIGC, WBNP and KNP);

3. in those areas in which some type of co-management is already taking place, the challenge is how to reinforce and extend the mechanisms. Where indigenous and other traditional peoples do not at present participate, the challenge is how to make it happen.

\section{Conclusion}

Indigenous and traditional peoples are actively interacting with protected areas around the world. The case studies presented here show only a small sample of these interactions. They depict situations that are occurring today in widely differing environments, from sea level to the highest mountains on Earth. They involve indigenous peoples groups with widely varying uses, traditions and customs; most of the groups have co-evolved in relative harmony with their respective natural environments.

All but one (KIGC) of the protected areas described here were proclaimed without the expressed consent of the people who previously inhabited lands or seas in the region. As 
a result, protected area authorities have been making decisions about species or ecosystems contained in these areas without the full involvement of the key stakeholders.

Fortunately this situation is now changing. This is partly because a more general acceptance of indigenous peoples' rights is emerging; and partly because it is now widely recognised that the involvement of indigenous peoples is essential to ensure long-term sustainability of the protected areas in which they live or have an interest. These ideas are, of course, reflected in Part A of this publication as a set of principles and guidelines.

However, in reality the involvement of indigenous and traditional peoples in the planning and decision-making processes, and empowerment of local groups, often fall short of the ideal (as in some of the examples described here). Within democratic systems of government there is more room (although not necessarily "enough") for the involvement of civil society (including indigenous and other traditional peoples) in protected area management; there are fewer opportunities in the case of centralised systems. One way to develop co-management of protected areas where it has been slow to take root could be through informal consultation and discussions between government agencies and communities of indigenous and other traditional peoples, perhaps facilitated by international organisations (Nepal, 1999).

\section{References}

Cohen, A. (1999). The mental health of indigenous peoples: an international overview. Cultural Survival Quarterly 23: 18-20.

Corbet, G.B. and Hill, J.E. (1991). A World List of Mammalian Species. Oxford University Press. 243pp.

Frost, D.R. (Ed.) (1985). Amphibian Species of the World: a Taxonomic and Geographical Reference. Allen Press and The Association of Systematics Collections, Lawrence, Kansas, USA. 735pp.

Howard, R. and Moore, A. (1984). A Complete Checklist of the Birds of the World. Macmillan, London. 732pp.

IUCN (1994). Guidelines for Protected Area Management Categories. CNPPA with the assistance of WCMC. IUCN, Gland, Switzerland and Cambridge, UK. x + $261 \mathrm{pp}$.

IUCN (1996). 1996 IUCN Red List of Threatened Animals. IUCN, Gland, Switzerland.

Mabberley, D.J. (1987). The Plant-book. Cambridge University Press, Cambridge, UK. $706 \mathrm{pp}$.

Nelson, J.S. (1984). Fishes of the World. John Wiley, New York.

Nepal, S.J. (1999). Indigenous peoples and protected areas: an overview. Unpublished report prepared on behalf of WWF-International.

Redford, K.H. and Mansour, J.A. (Ed.) (1996). Traditional peoples and biodiversity conservation in large tropical landscapes. America Verde Publications. The Nature Conservancy, Latin America and Caribbean Division, Arlington, Virginia. 267pp. 



\section{Case study 1}

\section{Kaa-lya del Gran Chaco National Park and Integrated Management Natural Area, Bolivia}

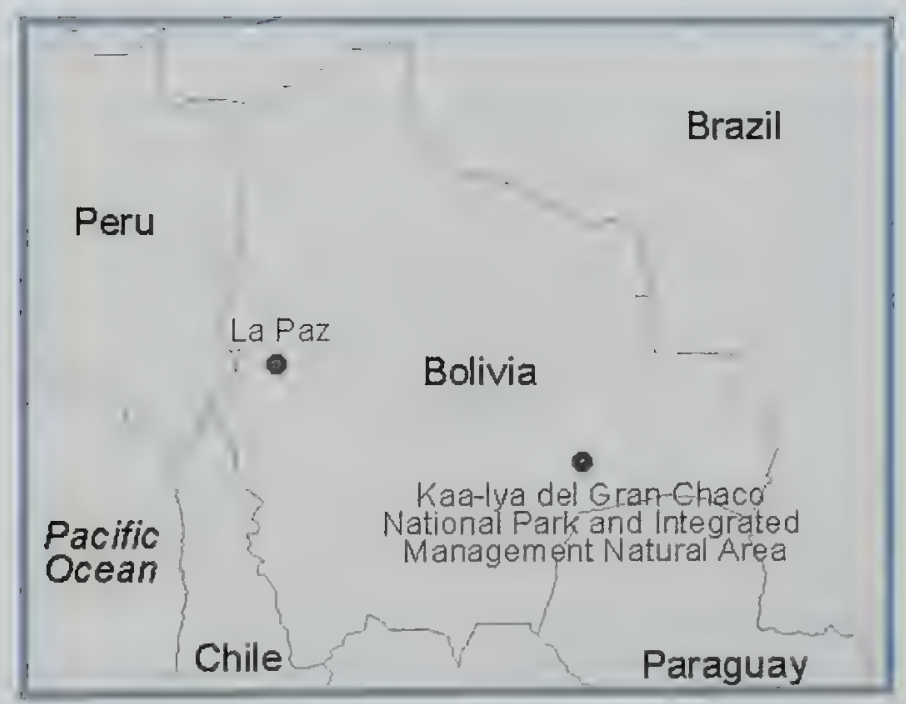





\section{Case study 1}

\section{Background information'1}

With a total area of $35,000 \mathrm{~km}^{2}$, the Kaa-Iya del Gran Chaco National Park and Integrated Management Natural Area (KIGC) constitutes one of the largest tracts of pristine Chaco ecosystem remaining in Bolivia. The site is located in the Santa Cruz Department, in the south central sector of the country. The southern limit of KIGC broadly coincides with the international border with Argentina. Its coordinates are $17^{\circ} 42^{\prime} \mathrm{S}-20^{\circ} 02^{\prime} \mathrm{S}, 60^{\circ} 03^{\prime}-62^{\circ} 31^{\prime} \mathrm{W}$.

KIGC is part of two distinct geological systems: the Chaco-Beniana Plains and the Serranias Chiquitanas. The landscape is generally flat with a few low undulating hills. The main river is the Parapeti, which has its origins in the locality of Irenda (Choreti) and flows into a vast area of wetlands named Izozog Swamps. Other watercourses are mostly temporary and infiltrate into the swamps themselves or into sandy terrain. KIGC protects an impressive sample of the Izozog Swamps, as well as the following five major habitat types: lowland sand-flats; lowland sub-humid forests; deciduous dry Chaco forests; scrublands; and Chaco xeric grasslands.

Although the Chaco is not very diverse floristically when compared to moister forests to the north, its flora is rich in endemic species. The southern sector of KIGC is covered by sub-humid Chaco forest with trees of "cuchi" Diplokeleha floribunda and the palm Trithrinax schizophylla. Its central eastern portion contains a well-drained Chaco forest with "sotillo" Athyana weinmannifolium and a low transitional formation with Tabebuia rosaceo-aurea. The area of the Izozog Swamps includes several different vegetation units: xeric forest with Bulnesia sarmientoi; tall forest of mesquite Prosopis chilensis; flooded forests with Cathornion polyanthum and Geoffroea striata; and scrublands of Tessaria integrifolia (Ergueta and Gomez, 1997).

There is a highly diverse fauna with 67 mammals and 285 birds, many of which are representative of the Gran Chaco and Brazilian Cerrado ecosystems. In particular, the area of dry Chaco forest within KIGC contains the highest mammalian species diversities in the Americas. KIGC is a stronghold for several species of conservation interest, such as Chacoan peccary Catagonus wagneri (EN), Dolichotis salinicola (LR/nt) and maned wolf Crysocyon brachiurus (VU). The Chacoan peccary is the largest and most specialised of the peccaries, and it was not recognised as a living species until 1974. It is endemic to the dry thorn forest of the Gran Chaco of Argentina, Bolivia and Paraguay where it lives in groups of about four individuals and feeds almost exclusively on cacti. This species has been extirpated over most of its range due to a combination of habitat destruction, hunting and probably disease. All surviving populations are declining and becoming increasingly isolated, and the species' best hope for survival is likely to be in the few protected areas within its range.

1 Case study prepared by J.Beltrán, UNEP-WCMC 
KIGC was officially declared as protected and included in the Bolivia's National System of Protected Areas (SNAP) by Supreme Decree No. 24,122 of 21 September 1995. The designations which compose KIGC have been assigned to IUCN Management Categories II, National Park (NP), and VI, Integrated Management Natural Area (IMNA). Overall, KIGC is administered and managed jointly by the Ministry of Sustainable Development and Planning and the indigenous organisation Capitania del Alto y Bajo Izozog (CABI). KIGC is found within the first indigenous municipal district in Bolivia - the Capitania of Izozog. By Bolivian law, "Capitanias" are indigenous municipalities that own and administer the land under their jurisdiction.

\section{Indigenous/Traditional people(s)}

The Eastern Lowland region of Bolivia has been occupied by indigenous peoples since well before the arrival of the Spaniards in the Bolivian Chaco, which took place between 1560 and 1564. Inhabitants of Izozog are called "Izoceños". They are principally of Guarani origin, but groups of Chiquitano and Ayoreo origin also occur. A total of 8,000 people, grouped into 22 communities, inhabit KIGC (Ergueta and Gomez, 1997).

At the time of the first European contacts, the Guarani occupied vast areas of southern Brazil, parts of Paraguay, and the neighbouring territories of southeastern Bolivia, northeastern Argentina and northern Uruguay. The Guarani Nation has undergone a process of migration with diversification, resulting in a large number of small groups or bands, each named after a chief or the localities they inhabited. Many of these names have been used either as alternatives to Guarani or to indicate sub-groups, with their exact status and relationship to each other unclear.

Three distinct groups of Guarani, Izoceño, Sava and Simba, now live in Bolivia with a total population of 34,000 people. They are mostly restricted to the southeast Departments of Santa Cruz, Chuquisaca and Tarija. The most numerous group is the GuaraniIzoceño, who live in the south central Parapeti River area and in the Tarija Department. They speak the Chiriguano language which is divided into three families: Tupi, TupiGuarani and Guarani.

Around 3,200 Ayoreos, distributed in 11 communities, live in a small area of south eastern Santa Cruz Department. Almost 46,500 Chiquitanos grouped in 323 communities inhabit a large part of the northeastern sector of the same department. The Ayoreo speak the Ayoreo language, which has one family, the Zamucoan. Chiquitanos speak the Chiquitano language, which is separated into two families: Macro-Ge and Chiquito.

The Chiquitanos originate from a fusion of various ethnic groups, and appear to have several times occupied their traditional territories before the arrival of the Spaniards. The first contact of Ayoreos with Europeans was during the time of the Jesuits, between 1691 and 1767. Having lost their land during the Chaco War, the Ayoreo people were forced by the arrival of Paraguayan settlers in the Bolivian Chaco and the discovery of oil wells there, to make contact with the outside world. Two Ayoreo groups continue to live traditionally in the central Chaco region of Paraguay. They belong to the Totobiegosode, which are the most aggressive of all indigenous groups in the Chaco when it comes to defending their land.

Originally, the Guarani relied upon slash-and-burn agriculture. Their main crops were cassava, maize, sweet potatoes, beans, squash, peanuts, cara (Dioscorea sp.), mangara (Aroidea sp.), bananas and papaya. This diet was supplemented by hunting, limited 
fishing and gathering. Men did the hunting and fishing and were responsible for the initial clearing for agriculture; cultivation was left to the women.

The most important economic unit was an extended family, which owned the agricultural fields and worked them communally. The extended family was also the most important residential and social unit. The family lived in a long house, known as a tapui: each tapui was often located equidistant from others, thus giving some early chroniclers the impression that each housed a separate "tribe". Apparently, each tapui was ruled by an old man, and the extended family was probably patrilineal and patrilocal. However, it has been pointed out that the bilateral kindred was also important, and that the Guarani also practiced matrilocality (i.e. where the husband goes to live with the bride's family). While territorial organisation beyond the tapui is unclear, each Guarani group or sub-division has its own social organisation. All Guarani share a religion which places supreme emphasis on the land as the origin and source of life, and as a gift of "the great father", Ñande Ru.

In the traditional health system of the Guarani, a pivotal rol 3 is reserved for the "payes", shamans who possess ancestral knowledge and supernatural healing powers. For the payes, illness is caused by bad spirits, (the "imbaekua") directed by someone to someone else. The spirits are embodied in an "insect" that possesses in its turn the human body. The spirit can cause a chain of separate diseases and mishaps over a long period of time (Umans, 1997).

As a result of intense contact with Europeans, there have been important changes in the way of life of Guarani people. The most significant of these have been in technology, economic sex roles and the shift of emphasis to the nuclear family. The tapui has almost entirely disappeared, and nuclear families now live in single-family dwellings. However, related families still tend to locate their dwellings near each other, following the practice from former times.

The Chiquitanos depend on slash-and-burn agriculture and livestock raising. They clear land for cassava, beans, bananas and other fruit trees; they fish for a variety of species; and they hunt and gather some food products, such as honey. They also harvest timber for home construction. During low periods for agricultural work, they work as labourers in odd jobs. The Chiquitano women manufacture cotton bags, hammocks and hats. In both Chiquitano and Ayoreo cultures, women play an important role in the family life. They are responsible for home life, agricultural work and transference of cultural traditions.

Historically, rights of indigenous peoples were heavily neglected in Bolivia and their cultures, languages and traditions were regarded as socially far inferior by the Europeandescended ruling class. However, during the first half of the 20 th century there were scattered cases of group uprisings against settlers who occupied land that traditional peoples claimed was theirs. In the 1940 s, several national indigenous conferences took place and rural unions were formed. In 1953, the Agrarian Reform Laws were first implemented by the National Revolutionary Movement (MNR) that had come to power in a revolution the previous year. The goal of the MNR was to assimilate Indians through the elimination of their autonomous culture and living patterns. This reform was focused on integrating lowland Indians with particular focus on reducing the extent of their dependence on agricultural land. While the Indians were given citizenship and the right to vote, they were discriminated against and denied political rights that were given to non-aboriginal people. 
Except for the Chiriguano people, who were strongly organised, lowland Indians were less organised than the highland Indians until the late 1970s. In 1982, various groups in eastern Bolivia combined to form the Indigenous Confederation of Eastern Bolivia (CIDOB). In 1984, the Chiquitano Indians of Santa Cruz formed the Intercommunity Organization of Eastern Lomerio (CICOL). The Coordinator of the Indigenous Peoples of the Beni (CPIB) was also set up during the late 1980s and led the "March for territory and dignity" in La Paz in 1992. In 1987, the Assembly of the Guarani People (APG) was formed to promote political action in the eastern region. They now hold the third largest position in the leading national indigenous organisation, the United Confederation of Peasant Workers of Bolivia (CSUTCB).

In 1982, the Union Democratica y Popular (UDP) took over the government, which was more sympathetic to the formation of new indigenous groups. However, economic decline within the country helped to bring MNR back into power in 1985. This government dissolved agreements about much of the communal land upon which Indians lived and worked, and many social programmes that supported indigenous people were cut. In response, indigenous groups in the lowlands mobilised themselves to demand social and economic reforms.

CABI is the long-standing political authority structure of the Guarani people of the Izozog. CABI first achieved legal recognition in 1990 under the name of API (Association of Izoceño Farmers), but since 1993 has acted through an indigenous NGO, Ivi Iyambae Foundation. In the late 1980s, it helped mobilise indigenous groups and, partly in response to this, reforms took place in the early 1990 s which led to the decentralisation of many aspects of governance to local municipalities. In addition, $\mathrm{CABI}$ and other organisations were given an active role in local government. These reforms coincided with growing national and international support for the environment and for indigenous peoples in general.

During the 1990s, several new laws were passed bringing benefits to the indigenous peoples. In 1993, the new Agrarian Reform Law (INRA) first recognised Bolivia as a multi-ethnic and multicultural country. This law allowed for the existence of community land ownership and legalised the creation of indigenous territories (Tierra Comunitaria de Origen - TCO). There are now over 30 well-substantiated claims for territories throughout eastern Bolivia, but most of these are at least partially disputed by other "owners". The new Forestry Law No. 1700 of 1996 requires that all natural resources harvested for sale from within TCO's must be accompanied by a management plan (Berena-Surkin, 2000).

A number of Supreme Decrees (SD) and Resolutions (SR) acknowledge the existence of various indigenous territories and authorise the budget for setting the boundaries of the so-called Multi-ethnic Indigenous Territories (TIM). These decrees assign certain areas to indigenous groups. They also regulate the land ownership regime, the use of natural resources, and prohibitions or rights of third parties. According to the SR No. 205862, the term territory must be used for a "determined geographic area which traditionally has been used and owned by original ethnic groups and has become a crucial factor for their survival and their economic, social and cultural development" (CIE, 2000).

A portion of KIGC and part of the territories occupied by indigenous communities will be affected by the construction of a gas pipeline that will begin $40 \mathrm{~km}$ southeast of Santa Cruz, Bolivia. The pipeline route will be approximately $3,100 \mathrm{~km}$ in length and go 
in a southeast direction ending at Porto Alegre, Brazil, passing through the Bolivian locality of Puerto Suarez on the Bolivia-Brazil border. This project is developed by Yacimientos Petroliferos Fiscales Bolivianos (YPFB) and Petrobras (from Brazil) with the participation of Transredes S.A. on the Bolivian side.

Gas Oriente S.A., a subsidiary of Transredes S.A., has been awarded a contract to construct a lateral gas pipeline branching from the principal route at kilometre post (KMP) 242 of the main pipeline, and will end at the city of Cuiaba in the neighbouring Brazilian State of Mato Grosso. The purpose of the Cuiaba Pipeline Project (CPP) is to transport and sell natural gas to an electric power plant in Cuiaba and provide for the energy demands in this region of Brazil. The total distance covered by the pipeline within the Bolivian territory is approximately $361 \mathrm{~km}$.

The Indigenous Peoples Development Plan (IPDP) is part of the Environmental Impact Assessment (EIA) for the Bolivian portion of the CPP. This IPDP aims to protect the interests of indigenous populations by: (1) preventing or mitigating possible negative impacts of the pipeline on the peoples' social, economic and cultural resources; and (2) encouraging the protection of traditional culture, history and archaeology in the project area (CIE, 2000).

\section{Involvement of indigenous peoples in the management and administration of KIGC}

The SNAP was established by means of the General Law of the Environment No.1,333 of 1992. The National Directorate for Biodiversity Conservation (DNCB), now the National Protected Areas Service (SERNAP), is responsible for the management of the system. However, the institutional framework currently in force provides for the active participation of civil society (NGOs, indigenous peoples and rural groups) in activities of co-management. The terms of co-management for a specific site should be clarified in an agreement between SERNAP and the co-managing group. Such a group must be legally recognised, and have the expertise and capacity necessary to fulfil its role effectively (Ministerio de Desarrollo Sostenible y Participación, 1997).

With a view to decentralising protected area management even further, SERNAP is now encouraging the formation of local Management Committees (MC). Each MC should be constituted by representatives of indigenous peoples, rural groups, municipalities, public organisations, NGOs and SERNAP itself. For each protected area, the MC would be in charge of: (a) participating in the definition of management objectives; (b) controlling and monitoring the site's management performance; (c) providing advice to, and supervising, the area's director on all matters related to the preparation and implementation of management and operational plans; and (d) assisting in identifying and obtaining financial support from external sources.

In 1995, KIGC was put under the joint management of the Ministry of Sustainable Development and Planning and CABI for an initial period of ten years. The terms and conditions of the agreement between the two organisations address the following issues:

ensuring that all planning, administration and management activities of KIGC are carried out in accordance with the environmental institutional framework currently in force in Bolivia, as well as in line with the management and operational plans for the area; 
involving the area's wardens and representatives of local communities in the management of KIGC;

a enhancing the quality of life and development of the local people.

In 1996, KIGC's Management Committee was established. It consists of the area's director and members of SERNAP, CABI, WCS, local municipalities, a community group of Chiquitanos (TURUBO), the Ayoreo Community of Santa Teresita and the group of women of the Izozog indigenous communities (CIMO). It is required to help define policies for the management of KIGC (Ayala Blusque, 1999). As part of this mandate, it has participated in the preparation, execution and evaluation of the management and operational plans for the site. KIGC's management plan comprises the five following programmes:

a) Operational programme: this includes the definitive demarcation of $\mathrm{KIGC}$, the construction of the area's headquarters in the locality of La Brecha, plus the creation of 10 camping areas to be located at strategic points. It has also overseen the construction of simple lodges for researchers and a visitor centre.

b) Surveillance programme: a team of park wardens has already been created. This team is responsible for the control and surveillance of designated areas, as well as for field research, and public relations with local communities and the public in general.

c) Natural Resources Management Programme: some seed funding was used by the Wildlife Conservation Society (WCS), the Center for the Study of Native Lands (CSNL) and CABI for a process of community-based mapping which provided basic information and trained participants for future wildlife survey work.

d) Public Use Programme: a project to identify the zones with capacity for tourism within KIGC has already been undertaken.

e) Regional Projection and Cooperation Programme: the purpose of this programme is to twin KIGC with other protected areas in Latin America, particularly those including Chaco ecosystem (Yandura, 1999).

The administration of the financial resources for KIGC's management was kept under the control of SERNAP. The funds were in the form of seed money provided by the Bolivian government, which channelled resources from the Swiss and the World Bank/Global Environment Facility (GEF).

SERNAP supported efforts by CABI and WCS to negotiate an agreement with the United States Agency for International Development (USAID). Under this agreement, USAID would provide funding for the development of a project with the following purposes: (a) to build up CABI's overall institutional capacity; (b) to initiate environmental education and training programmes in Izozog and the eastern lowland region of Bolivia; (c) to prepare and implement KIGC's management plan; and (d) to begin a programme of research in support of community-based wildlife management (CWM).

This partnership between WCS and CABI stemmed from their common interest to protect the Gran Chaco ecosystem. CABI's goal was to use a legally-recognised means to block the expansion of agriculture and to provide a model of development based on principles of conservation and sustainable use. WCS's goal was to protect the region's biodiversity. USAID recognised that KIGC's objectives could only be met with a 
complementary programme based on the involvement of the Guarani-Izoceño people, who had lived in the area for generations.

Izoceño leaders said it was essential to share the ideas for such a collaborative programme with the communities living in KIGC before the planning went any further. Immediately, a team of Bolivian biologists and Izoceño para-biologists began to establish the local links between field research and community-based conservation. The emphasis was on applied research with results that could be transmitted to local communities and incorporated into management action. Part of this research directly engages hunters in self-monitoring their activities, specimen collection, and the capture and census of wildlife. In community discussions, the results were compared with hunters' knowledge and beliefs: from this came practical proposals for management that communities would be willing to implement.

CWM means not only harvesting wildlife for subsistence purposes, but also seeking new opportunities for income generation. Within KIGC, several species of wildlife may potentially be exploited sustainably. Since 1996, more than 200 hunters from all the Guarani-Izoceño communities have voluntarily registered data on hunted animals in personal data notebooks: over 3,000 mammals, 1,500 birds, 100 reptiles and 2,000kg of fish. Commercial hunting is minimal since the collapse of the international fur trade (for spotted cats and foxes) in the 1980s. Hunting of parrots and songbirds for the pet trade continues on a relatively small scale.

The nomadic gathering of products of the Ayoreo Indians is currently allowed. The Chiquitanos of Lomerio have agreed to ensure that the information on resource use that they provide is as accurate as possible. In some indigenous communities, this has led to conflicts with outsiders who have been given permission by the government to harvest resources without consideration for the local people.

As part of the process for mitigating the impact of the construction of the CPP, Gas Oriente S.A. will contribute US\$1 million to be used in the creation of an Environmental Fund. This is to be considered as a "seed fund" to contribute to obtaining future donations, which would then be used to cover the long-term financial needs of KIGC. Overall, project sponsors have committed more than US\$12 million to mitigate the primary and secondary short-term impacts of building the CPP (CIE, 2000).

\section{Traditional knowledge and practices}

In general, the Guarani-Izoceños have had a long tradition of conservation awareness and action. They continue to use traditional social organisation to control their own hunting and fishing in the area. The Chiquitano and Ayoreo communities also maintain a close relationship with their natural environment, relying upon the forest for items used in housekeeping, medicinal plants and raw material for handicrafts. In recent times, however, hunting and fishing have decreased in importance.

\section{Critical evaluation of lessons learnts}

The interactions that have taken place between indigenous peoples, the Bolivian government, international NGOs and the business sector within the framework of KIGC, have clearly contributed to improving the general situation of the Chaco ecosystem in this sector of eastern Bolivia. These partnerships have been successful where they adopt an 
integrated and comprehensive approach, so as to ensure the conservation of the ecosystem, and the long-term improvement of the conditions of the resident indigenous peoples.

For example, the partnership between CABI and WCS working with funds provided by USAID has produced very positive results, specifically in relation to communitybased wildlife management. It has brought benefits to the Izoceños who, in spite of having a good understanding of the habits of the local wildlife, did not have the experience to assess wildlife population health and nutritional requirements. WCS agreed to provide the necessary technical assistance, but it was agreed that nothing would be done without the concurrence of the Izoceños. The role of WCS was to strengthen CABI's administrative capacity, carry out scientifically-sound inventories, teach the Izoceños to monitor the health of wildlife, and assist teacher training schools for environmental education.

The Izocenos saw a number of positive results from this programme. By using the self monitoring of resource use to engage groups in participatory investigation, interesting questions arose. Data collected in this way will not leave the community unless the people want it to. The communities involved are empowered by their own informationgathering efforts and the control they have over them. The groups indeed began to discover their own potential to analyse problems. It is hoped that such growing selfreliance and self-confidence will eventually lead to community-created management plans which can be adapted for local cultural, economic and environmental conditions (Towsend, 1998).

Other successes have been that WCS has received strong support from CABI leadership, as well as broad participation by community members in providing data and attending meetings. There is no immediate conservation crisis - KIGC is immense and, even in the Izoceño hunting and livestock areas, most species appear to be maintaining important populations (USAID, 1997).

$\mathrm{CABI}$ is emerging from this context as a unique example of indigenous control of natural resource conservation and development. To date, CABI's role in decentralisation includes co-management of KIGC, co-administration of the USAID-funded project with critical environmental management components, the creation of the IPDP and the governance of a sub-municipal district. But, while this model of decentralisation has led to greater biodiversity conservation and land tenure security for the Izoceños, CABI has not yet shown how to achieve improved living conditions for indigenous peoples alongside the maintenance of community identity, culture and "tradition" (BeneriaSurkin, 2000).

The WCS/CABI conservation organisation/indigenous organisation partnership has moved beyond the initial successful creation of a national park to face other long-term challenges. CABl's central concern is with socio-economic development, whereas WCS's interests are in biodiversity conservation. These interests need not conflict so long as income-generating activities are based on the sustainable management of natural resources and can identify alternative development models that maintain the Izoceño community and the natural environment of the Chaco (Noss, 2000). 


\section{Major challenges for the future}

The case of KIGC illustrates the convenience of establishing partnerships between conservation authorities and groups of indigenous and other traditional peoples, and the need to do so as early as possible in planning and managing protected areas. Most of the initiatives described here are highly innovative, particularly for a country which, in the past, was not noted for the recognition of indigenous rights. The challenge now is to consolidate the still weak civil society mechanisms for participation, and ensure that the benefits derived from $\mathrm{KIGC}$ reach all the communities that interact with the protected area.

\section{References}

Apurani Charico, M. (1999). Proyecto Kaa-Iya. Actas del Tallel sobre experiencias prácticas en gestión de áreas protegidas por los pueblos índigenas de Iberoamérica. November 29-December 5. Pp. 223-232.

Ayala Blusque, R. (1998). Areas Protegidas del Departamento de Tarija. PROMETA, IYA-Programa de Conservación y Desarrollo, Grupo Dru. La Paz, Bolivia. 176pp.

Beneria-Surkin, J. (2000). Is decentralization a plan without evil? A case study of conservation development strategies in Izozog, Bolivia. http://www.isop.edu/ intercom/spring2000/LACstudent.htm.

Cuiaba Integrated Energy (CIE) Web site (2000). http://www.cuiabaenergy.com/

Ergueta, S. y Gomez, H. (Ed.) (1997). Directorio de Areas Protegidas de Bolivia. Centro de Datos para la Conservación (CDC), Bolivia.

Ministerio de Desarrollo Sostenible y Participación (1997). Implementación del Convenio sobre Diversidad Biológica. Primer Informe Nacional de Bolivia. La Paz-Bolivia. http://www.biodiv.org/natrep/Bolivia/Bolivia.pdf

Noss, A. (2000). Community based wildlife management in the Bolivian Chaco. Social Change and Development News 12.

Towsend, W. (1998). Participatory investigation as a means to promote community based management: examples from the lowland Bolivia. http://srdis.ciesin.org/ cases/bolivia-002.html

Ulman, J. (1999). The rapid appraisal of a knowledge system: the health system of Guarani Indians in Bolivia.

USAID (1997). Procurement alternative for collaboration: USAID/Bolivia's Chaco Initiative. http://www.info.usaid.gov/about/part_devel/docs/prtpractl 1 .htm.

Yandura, A. (1999). Gestión de áreas protegidas en el Chaco. Actas del Taller sobre experiencias prácticas en gestión de áreas protegidas por los pueblos índigenas de Iberoamérica. 29 November- 5 December. Pp. 211-222. 



\section{Case study 2}

\section{Cayos Miskitos and Franja Costera Marine Biological Reserve, Nicaragua}

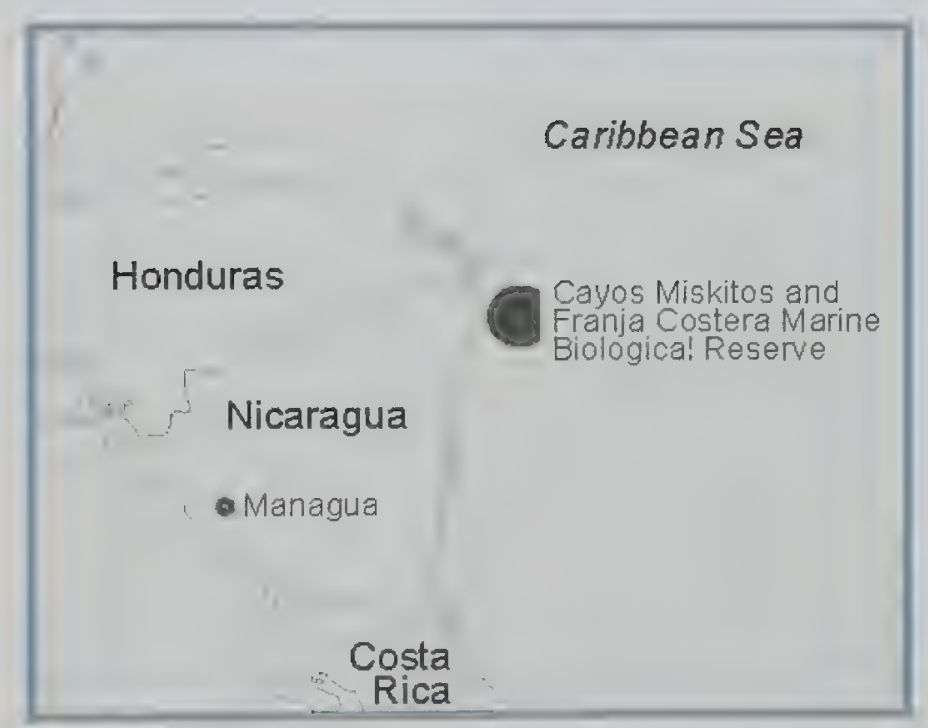





\section{Case study 2}

\section{Background information ${ }^{2}$}

The Cayos Miskitos and Franja Costera Marine Biological Reserve (RBMCM) is located on the northeast coast of Nicaragua, in the territory inhabited by the Miskito Indigenous People. The region is part of what is collectively called the Mosquitia and the Mosquito Coast of Nicaragua and Honduras, bounded to the north and east by the Caribbean Sea. RBMCM has an area of almost $13,000 \mathrm{~km}^{2}$ and its limits extend for $40 \mathrm{~km}$ around the Miskito Key, which is the largest among the 30 or so offshore keys and rocks constituting the whole group of Miskitos Keys. The reserve also includes a $20 \mathrm{~km}$ coastal strip extending between the locality of Wouhta to the south and Cabo Gracias a Dios in Honduras to the north. The coordinates at its central point are $14^{\circ} 23^{\prime} \mathrm{N}-82^{\circ} 48^{\prime} \mathrm{W}$.

Nicaragua's Caribbean coastal zone includes a broad range of environments, such as brackish wetlands on the land, and nearshore and offshore benthic communities. On land, 90 percent of Nicaragua's watersheds drain towards the east coast through 11 major rivers. The nutrient loads and freshwater brought by these rivers are vital to the ecological functioning of the coastal region, including the neighbouring marine environment.

Five of the world's most productive ecosystems are found in RBMCM: coral reefs; sea-grass pastures; mangroves, brackish lagoons and marshes; estuaries; and tropical forests. These ecosystems support an outstanding biodiversity, with several species of conservation concern occurring in large numbers. The reserve harbours the region's greatest population of Caribbean manattee Trichechus manatus (VU) as well as huge aggregations of resident and migratory waterfowl. It is a stronghold for large populations of hawksbill Eretmochely's imbricata (CR) and green Chelonia midas (EN) sea turtles, and also protects the economically most significant fishing grounds in the Caribbean for lobster and shrimp.

The site was officially designated as a Marine Biological Reserve by Executive Decree No. 43 of 30 October 1991. In Nicaragua's legislation, this designation is equivalent to a Strict Nature Reserve (IUCN Management Category Ia) within which only scientific research activities are permitted. However, land and sea use restrictions inside RBMCM are not that stringent and hence it has recently been proposed to reclassify it as a Biosphere Reserve (Category VI), before proceeding to its definitive inclusion into the System of Protected Areas of Nicaragua (SINAP).

Six of the offshore keys are privately owned (Crawl, Wild Cane, Baboon, Water, Lime and Vincent); the rest belong to 38 Miskito communities, which control the access to the lagoons, marshes, mangroves and reef resources. RBMCM was established by means of a co-operative agreement between these communities and the Ministry of the Environment of Nicaragua (MARENA). The communities along the Coco and Prinzapolka

2 Case study prepared by J.Beltrán, UNEP-WCMC, and Fausto Cepeda, WWF Nicaragua 
rivers have organised themselves into a non-government organisation (Mikupia), which will take direct responsibility for, and benefit from, the management of RBMCM. Those inhabiting the area of Bilwi near Puerto Cabezas also participate in this agreement, which received support from WWF, the United States Agency for International Development (USAID) and the Caribbean Conservation Corporation (CCC). An Inter-institutional Commission was established to co-ordinate the planning and management of the reserve. The commission is convened (and chaired) by MARENA, and also includes the Fishing Administration of Nicaragua (ADPESCA), the Ministry of the Interior, the Government of the North Atlantic Autonomous Region (RAAN), Mikupia and the communities living in Bilwi.

\section{Indigenous/Traditional people(s)}

RBMCM is located in the Atlantic Region of Nicaragua, which covers more than half of the country's land territory. A total of 400,000 people, or 10 percent of the entire population of Nicaragua, live in this vast area, where rivers are the main form of transportation.

With a population of 155,000 people, the Miskitos constitute the largest ethnic group in the region, followed closely by mestizos (ladinos) of European/Amerindian descent. The Miskitos are concentrated on Puerto Cabezas and other towns and villages scattered across RAAN, and have also settled in areas of the South Atlantic Autonomous Region (RAAS). In addition, around 26,000 Creoles (Afro-Caribbeans) live in Bluefields, Pearl Lagoon and Corn Island; 8,000 Sumu Amerindians inhabit the northern interior highlands; 1,500 Garifunas occupy the coast north of Bluefields; and 800 Rama Amerindians occupy villages south of Bluefields. The total Miskito population living within the reserve was estimated to be 25,000 inhabitants in 1995 (this figure does not include the population of Bilwi, the RAAN capital city).

The Mosquitia and Mosquito Coast have been the homeland of the Miskito people since well before recorded history. Some historic accounts indicate that they have always been the dominant cultural force in the region. Nowadays, the Miskito culture still prevails in an area extending from Rio San Juan in Nicaragua's Department of Rio San Juan, to Laguna Ibans in the Department of Gracias a Dios, in Honduras.

Traditionally, Miskitos have lived as hunters, subsistence farmers and fishermen. They use the once abundant populations of sea turtles, which were a key resource for them. In the past, sea turtles have not only covered nutritional needs, but were also a cultural symbol within Miskito society. Nowadays, the Miskito economy has changed somewhat, though most groups still practice swidden agriculture (cassava, banana, maize, beans and rice) and gather forest products. In addition, many kinds of fruit-trees and vegetables are cultivated. Hunting and fishing are still common, but many families living in the keys now depend on diving for lobster as the main source of annual income. Up to 4,000 Miskito men are involved in this activity in any one season.

The communities control access to traditional land and marine resources in the region and neither the Central nor the Autonomous Government has so far been able to regulate their use. They employ a traditional system of Inter-communal Committees whose meetings and consensus decision-making is used to establish the level and zones of harvesting lobster and other species. 
Miskitos speak the Miskito language: this belongs to the linguistic family Misumalpa and is mixed with a large number of Spanish and English words. Miskitos are bilingual, they use Miskito at home or in their villages and learn Spanish at school. Five distinct dialects can be recognised, four of which are used in Nicaraguan Mosquitia: Tawira, Baymuna, Wanki and Cabo. Wanki is spoken mostly around Puerto Cabezas; the others are used in settlements to the southwest. The fifth dialect, the Honduran Miskito is typical of the Honduran Mosquitia.

As a result of past British influence, the prevailing religion among Miskitos is Protestant (Moravian). William Dampier, a British explorer who became involved with buccaneers in Central America, did not recognise any religion or any ceremonies or superstitions among the Miskitos. They seemed to fear the devil, however, whom they called Wallesaw and said he often appeared to the shaman. In fact, Miskitos are very spiritual people and believe that there is a spirit inside every animal and plant.

The Atlantic Region of Nicaragua, which has always been a world apart from the rest of the country, provides the context in which the historic evolution of the Miskitos took place. The region was never really colonised by the Spanish to the extent that the Pacific and Central regions were. In 1687, the governor of Jamaica established an English protectorate over the area and named a Miskito chief the leading authority. The British relinquished protection over the territory to the Nicaraguan government in 1860 on the understanding that it would be a self-governing region. The so-called "Mosquitia Reserve" enjoyed relative autonomy until it was occupied by Nicaraguan troops in 1894.

Nicaraguan efforts at colonisation in the region at that time prompted resistance from Miskitos and Creoles. At the request of Nicaragua, US Marines and British troops were sent into the region, and the resistance ended in 1905 with the signature of the Harrison Altamirano Treaty, by which indigenous peoples were granted communal land titles. The Miskitos were then employed by US mining and agricultural companies who ran the economy until they abandoned the region after a series of diseases devastated their crops in the 1960s.

Various political regimes have tried to impose their control over the Atlantic Region, usually with negative results. From 1936 to 1979, during the rule of the Somoza family, the area was subjected to intense deforestation, farming and commercial fishing. In 1974, the indigenous peoples of the region organised themselves for the first time to protect their rights and traditional lands through the Alliance for the Progress of Miskitos and Sumus (Alpromisu).

After the overthrow of Somoza's dictatorship in 1979, the Sandinista Government attempted to incorporate the Atlantic Region into the revolutionary process. Failing to recognise the cultural uniqueness of the region, Sandinistas launched literacy programmes in Spanish and nationalised untitled lands of communal property. The inhabitants of the region formed a new organisation called Mascot, Rama and Sandinista United (Misurasata), which consisted of over 80 percent Miskito members and supported claims for indigenous communal land grants and the promotion of their language and culture.

Misurasata became increasingly militant and raided Sandinista installations from Honduras. In 1981, it was considered as a rebel movement and banned. In January 1982 Sandinistas forcibly relocated 10,000 Miskitos from the bank of the Coco River to separate camps further south, as well as destroying as many as 100 villages. Approximately 10,000 Miskitos escaped into Honduras and were placed in United Nations 
refugee camps, and Misurasata relocated itself in Costa Rica. From 1982 to 1984, some 4,000 Miskito guerrillas fought with Sandinista troops and 10,000 more people escaped to Honduras as refugees.

In 1984, the Sandinista Government began to seek peace with Miskitos. They released counter-revolutionaries who had been jailed during the 1982/3 state of emergency, and an amnesty was offered to all those still fighting the war. This prompted a trickle of the Miskito refugees back to their homelands. The Sandinistas also began to replace the governing positions of the Atlantic Region with Miskitos. Negotiations drew to a conclusion in September 1987, when sufficient concessions were made to Misurasata's principal demands. Autonomy was given to the Atlantic Region on the understanding that the area, as a vital part of Nicaragua, would remain subject to the Nicaraguan Constitution.

The Atlantic Region is now divided into the two autonomous regions, RAAN and RAAS. Each was given its own 45-member council, which in turn elects a governor. Both regions are also represented in the National Assembly with three and two representatives, respectively. The governor is the elected coordinator of the region and carries out central and regional governmental decisions. In theory, the two regions share responsibility with the Nicaraguan government for economic, cultural and environmental affairs. This guarantees the preservation of Miskito's cultural heritage, including linguistic rights, and establishes regional control over their natural resources. However, successive Nicaraguan Governments have sought to obstruct the development of the autonomous arrangements, claiming that they were an invention of Sandinistas.

In 1987, Yatama (Descendants of Mother Earth) became the successor to Misurasata, aiming to unify the various indigenous organisations. Its constituents were a combination of former "contras" (who had fought the Sandinistas) and Misurasata members. This group primarily represents the Miskito population and the Sumu and Rama peoples; some of its members are still very militant. Its goals are to encourage further autonomy and greater protection of indigenous rights, and to curb alleged corruption of some members of the autonomous councils.

The end of the war brought with it greater colonisation pressures from commercial loggers, cattle ranchers and slash-and-burn farmers, all of which threaten the customs, traditions and land ownership rights of the Miskitos. Logging and fishing concessions, granted by the central government without the knowledge or participation of the Miskito communities, could harm the people and the environment. Also, vessels from more than a dozen countries are removing marine resources on a large scale, particularly lobster, shrimp and sea turtles.

\section{Involvement of the indigenous peoples in the management and administration of RBMCM}

Nicaragua's laws, regulations and decrees define rights and responsibilities of the public and non-public sectors regarding the protection and wise use of natural resources in the country. In particular, the General Law of the Environment No. 217 of 1996 instituted the legal basis for the creation of SINAP. Its management is the responsibility of the General Directorate of Protected Areas (DGAP), which is one of the three technical general directorates that exist within MARENA. 
Article 22 of Law 217 indicates that MARENA is responsible for administering SINAP but can, in some cases, delegate this responsibility to third parties (co-management). The entity in charge of co-managing a protected area must be non-profitable and follow the directives of an officially-approved management plan. A contract stating the conditions of co-management has to be signed by MARENA and a non-government organisation for each protected area that this regime covers. Such conditions include matters such as protection of natural resources, surveillance, administration and allocation of funds, contract of staff and installation or removal of infrastructure.

In 1995, it was first proposed that RBMCM be co-managed by the organisations which are members of the Inter-Institutional Commission. This failed in the absence of an adequate institutional framework, which was later provided by Law 217. MARENA has recently re-initiated the process of public consultation so as to define the roles and responsibilities of the co-managing organisations. However, there still is debate over which activities will finally be delegated to the organisations and which will be carried out by MARENA. In principle, the Ministry is willing to share the responsibility for activities of conservation, protection and surveillance, but wishes to retain responsibility for giving forest, mining or fishing concessions.

Also in 1995, the first management plan for RBMCM was elaborated by a Planning Technical Team (ETP) integrated by members of MARENA, Mikupia and the communities of Bilwi, with participation of CCC and external consultants. This plan identified four key management issues within the reserve:

a) Definitive demarcation of the communal tervitories: a Law of Property of the Indigenous Territories in the Atlantic Coast is under preparation. This law would recognise the Miskito communities as legal entities, as well as legalise the existing informal mechanisms of appropriation and transference of communal property. The draft law will be presented soon to the National Assembly for consideration.

b) Regulation of the extraction of marine resources, particularly lobster: current levels of diving for lobster and harvest of other marine resources such as shrimps are clearly unsustainable. There are fewer lobsters each year, and this is forcing Miskito divers to go deeper into the sea and put their lives at even greater risk. Hence, it is urgent to regulate this activity and also to investigate the marketability of alternative marine resources such as conch, sea urchins, sea cucumbers and kelp. It would also be helpful to develop businesses that can be run by Miskito women, while men are away fishing, such as aquaculture, organic cacao production and butterfly farming.

c) Control of extractive activities inland: there is a clear need to prohibit or regulate slash-and-burn agriculture and timber extraction in lowland tropical forest, particularly along the margins of the rivers and watercourses that flow into the Caribbean Sea. These activities are responsible for increased levels of siltation, which threaten the survival of coastal lagoons and offshore reefs.

d) Change of the designation and management objectives of the reserve: the current management objectives of RBMCM are incompatible with the traditional use made of resources within the reserve. Therefore MARENA and the InterInstitutional Commission intend to reclassify the Cayos Miskitos y Franja Costera as a Biosphere Reserve, a legal designation within which it would be possible to combine the regulated extraction of land and marine resources with the strict protection of habitats and species of conservation interest. 
With support from WWF-Central America and the USAID-funded Coastal Zone Management Component of the Central America Regional Environmental Programme (PROARCA/Costas), two Local Management Committees (LMC) have been set up. One, Mismakad, is currently working in the Miskito Keys area; the other is concentrated on the Karata and Wouhta lagoons, to the south of Bilwi. They coordinate fishing activities, and are responsible for helping to resolve any problems that may arise with other communities, for example over access to and use of resources in these areas. They aim to prepare management plans for each of the species that are under exploitation and to explore economic alternatives for the communities. The committees have almost completed the preparation of a management plan for fishing in the coastal lagoons, a plan for harvesting lobster, and rules and standards for the conservation of sea turtles.

WWF-Central America and the Ecotourism Miskito Association are currently developing an eco-tourism programme for the reserve, which is expected to begin shortly. Visitors will be picked up at the airport of Puerto Cabezas and given a guided visit to the communities of Karata, Wawa, Haulover and Wouhta. Each of these communities will develop an infrastructure of basic lodges with private toilets and solar-generated electricity.

\section{Traditional knowledge and practices of Miskitos}

The Moravian and other missionary church traditions supplanted many of the traditional cultural practices of the Miskitos long ago. Ever since their first contact with Europeans, Miskitos have engaged with cultural outsiders, trading their labour for foreign goods or wages in a variety of commercial ventures. Their most binding cultural traits are now a common language and the Moravian religion.

In the context of the University of Autonomous Regions of the Nicaraguan Caribbean Coast (URACCAN), several different efforts directed at reactivating and revitalising Miskito traditional knowledge and practices have been initiated. This has represented a challenge, because many professionals of Miskito origin have graduated from western education systems. Indigenous academics are required to assemble the vast and rich historic indigenous experience and knowledge, but not to change it.

For example, Miskitos confide in their "sukias and curanderos" (healers) more than in western medicinal practices. This tradition responds to their vision and interpretation of health and disease. The Institute for Traditional Medicine and Community Development, which is part of URACCAN, aims to help promote traditional medicinal practices, as part of the development of a new health model that respects the particularities of each ethnic group living in RAAN. The Institute carries out research and community education projects, and publishes and disseminates information. The Austrian Co-operation Service for Development/OED has supported its activities.

Before the end of the war with the Sandinistas, the Miskitos used marine and land resources in a sustainable way. A major alteration to this tradition has come about with the expansion of the lobster and forest industries. Nowadays, Miskitos compete with, or are a direct part of the aggressive, more technical national companies (e.g. Atlanor, for the fishing industry, and Madensa, for forest industry), which operate in a completely unregulated market. 


\section{Critical evaluation of lessons learnt}

The relationships between the Miskito communities inhabiting the Atlantic Region of Nicaragua and the central and autonomous governments have long been difficult, and there has been little understanding and recognition by the authorities of the traditions and customs of the indigenous communities. The central government made a move forward when it invited Miskito groups to participate in the planning and management of RBMCM, but this trend needs to be maintained and intensified to build genuine mutual cooperation.

Meanwhile, the Miskito coastal communities maintain their demands for full control over access to marine and land resources in the area and seek recognition of their traditional rights. They campaign for the removal of pirate fishing vessels from their waters; local Miskito leaders request the implementation of clear rules for the sustainable harvest of lobster, including seasonal bans and creation of strictly protected areas. Within the reserve, however, the management committees do appear to be having some success in the improving collaborative management.

\section{Major challenges or directions for the future}

The current atmosphere of increased co-operation between the Miskito communities and government authorities should be consolidated and, if possible, extended further. Land ownership is a priority issue, and there is an urgent need to resolve disputes with commercial loggers, cattle ranchers and slash-and-burn farmers. The on-going dispute over access to marine resources is also a priority for resolution at governmental level. Finally, the government should extend community participation to include a power to issue concessions and control the right to use marine and land resources.

\section{References}

The following are some of the most relevant references that were consulted for the preparation of this case study:

Borland, K. (1999). Folklife of Miami's Nicaraguan communities. Historical Museum of Southern Florida. http://www.historical-museum.org/folklife/folknica.htm.

Herlihy, P. y Herlihy, L. (1989). Patrimonio cultural de la Reserva de la Biosfera de Rio Platano. In Murphy, V. (Ed.) La Resenva de la Biosfera del Rio Platano: herencia de nuestro pasado. Pp. 9-17.

Nietschmann, B. (1981). The exploitation of hawksbill turtles, East coast of Nicaragua: results and recommendations from a preliminary study. $10 \mathrm{pp}$.

Nietschmann, B. (1986). Nicaragua and the Indian revolution. http:/www.cwis.org fwdp/Americas/nicar-re.txt.

Nietschmann, B. (1991). Miskito Coast Protected Area. National Rescurch and Exploration 7: 232-34. 
Nietschmann, B. (1993). The development of autonomy in the Miskito Nation. http://carbon.cudenver.edu/public/fwc/Issue4/nicaragua-1.html.

Molina Marcia, C. (2000). De cara al tercer milenio: la visión indígena y multiétnica. http://www.puebloindio.org/moskitia/DOCUMENGC.html.

Ryan. J.D., Miller, J.L., Zapata, Y. Downs, O. and Chan, R. (1993). Great Corn Island, Nicaragua Environment and development in coastal regions and in small islands.

UNEP-CAR/RCU (1996). Status of Protected Area Systems in the Wider Caribbean Region. Country Profiles: Nicaragua. CEP Technical Report No. 36. 


\section{Case study 3}

\section{Sarstoon-Temash National Park, Belize}

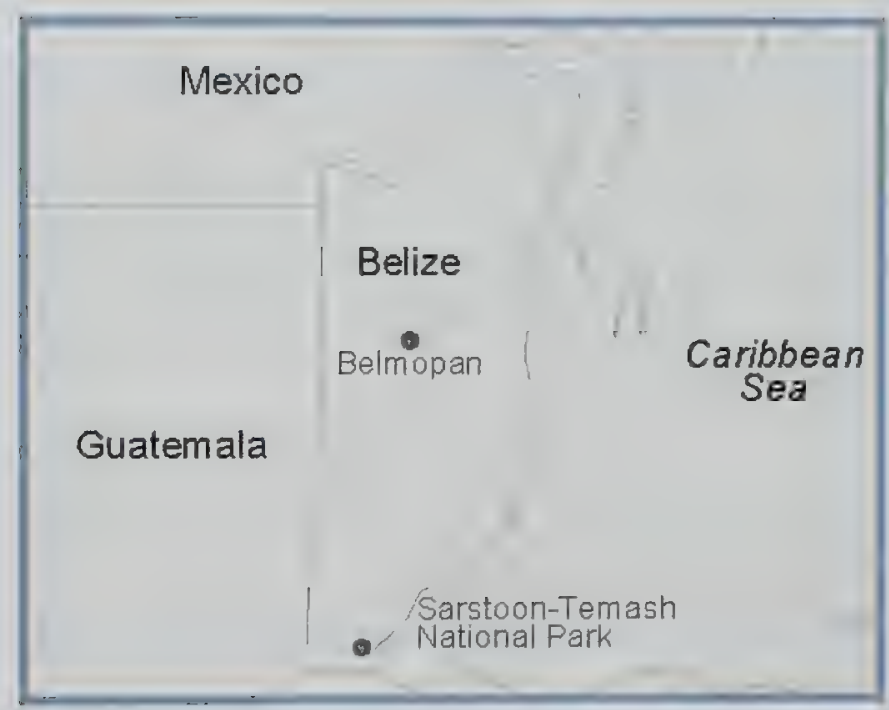





\section{Case study 3}

\section{Background Information ${ }^{3}$}

The Sarstoon-Temash National Park (STNP) is located in Belize's southernmost Toledo District, alongside the Guatemalan border. With a land area of $168 \mathrm{~km}^{2}$, the park is the second largest protected area in the country, and includes the entire watersheds of the Temash and Sarstoon rivers.

STNP protects a wetland complex and encompasses the country's most highly developed riverine mangrove, with red mangrove Rhizophora mangle as the dominant species. The Temash and Sarstoon rivers flow into the Caribbean Ocean. Both are slow flowing and under tidal influence. Upstream on the Temash, the channel reaches depths of over 30 metres.

The broad ecological characteristics of the park have been established from overflight videos and hydrology, vegetation and geology maps. STNP contains an outstanding diversity. However, while Zisman (1989) indicated that the site contains large populations of Guatemalan howler monkey Alouatta villosa, most details of the area's fauna and flora have yet to be recorded. No species list exists and even the local residents are uncertain about the full variety of wildlife that may occur in the park.

STNP was created by Statutory Instrument No. 42 of May 1994 (Zisman, 1996) and was assigned IUCN Protected Area Management Category II. The land ownership inside the park is unclear.

\section{Indigenous/Traditional group(s)}

The survival of Sarstoon-Temash's unique wetlands and mangrove complex owes much to the careful management practices of the local indigenous peoples who have historically used its resources. The area is far from national centres of economic and infrastructure development, and this has helped greatly in its preservation.

There are five indigenous communities located close to the border of the SNTP, who have traditionally used, interacted with and depended upon the natural resources located within it. Four of these are inland villages populated by approximately 550 Kekchi Mayans, whilst Barranco, a Garifuna coastal-oriented community, has just over 100 inhabitants. The communities' first languages are Kekchi Maya and Garifuna, respectively, with English spoken as a second language by most Barranco residents, and by $60 \%$ of the Kekchi Mayans. Years of economic and social exchanges between Barranco and Kekchi Maya communities have led to a good deal of mutual understanding and respect, rather than the traditionally tense relations which usually exist between Garifuna and other Maya groups.

3 Case study prepared by E.Caddy, G.Ch'oc and S.Paul for WWF-International 
The Toledo District was an area of Maya settlement long before the arrival of Europeans and the creation of the state of Belize (Berkey, 1994; Leventhal, 1997). The Maya are traditionally an itinerant people, the result of shifting agricultural practices and the wars and upheavals during the period of colonial occupation. Though both the number and location of Maya villages in southern Belize have changed over the centuries, the Maya's occupation of Toledo has remained constant throughout.

The arrival of the Garifuna in Belize occurred at the beginning of the 19th century. The Garifuna, also known as Afro-Caribs, originated in the Caribbean island of St.Vincent, where Arawak Indians from South America had migrated and mixed with the local Carib inhabitants, and later, in the 1600 s, with escaped African slaves. The Afro-Caribs were a prosperous and dominating race which the British found difficult to control. In 1797, the British expelled the Garifuna to Honduras's Bay Islands. Later migrations by the Garifuna north and south along Central America's Caribbean seaboard brought them to the region of what is now STNP by the early 1800 s. The community of Barranco was established sometime around 1850 , prior to the area's incorporation into British Honduras (now Belize), and has been continuous ever since.

Mayan land tenure is governed by a traditional communal land management system, rather than the State system of individual private property ownership. The allocation of parcels of land between community members is determined and overseen by the village leaders, the Alcaldes, in consultation with the community and according to the traditional governance rules of the communal land system. The Maya's ability to survive for so long on Toledo's poor tropical soils is good evidence of their intimate understanding of the regional ecology. This traditional system is, lowever, very vulnerable, since most Maya communities, including those adjacent to the park, do not have legal titles to their lands. Maya villages are therefore at risk from international developers, inequitable governmental land distribution policies and land invasions.

The Maya, like all small farmers in Toledo's depressed economy, face a crisis. They have grown increasingly dependent on a cash economy, but their income sources, which are limited to the sale of subsistence crops such as corn, beans and rice, can no longer cover their basis needs. Population increase, economic depression, land invasions and a lack of marketing support place a great strain on their traditional land tenure and slash-and-burn subsistence agricultural system (known as milpa).

In Barranco, economic depression has led to a steady exodus of its residents to other areas of Belize and the United States. The Garifuna, who were traditionally expert fishermen, and also grew bananas and rice for export, found their livelihoods undermined by the 1980 s with the depletion of fish stocks, the domination of the banana market by large growers and the closure of the government rice buying centre. Barranco's remaining residents now rely heavily on assistance from family members living abroad. Although residents of Barranco are no longer as dependent on farming as they once were, they too are concerned about land invasions and their own insecure land tenure position. Like the Maya, they wish to secure legal claims to their ancestral lands, which they regard as their communal patrimony.

In recent years, Toledo's pristine resources have captured the attention of international and national developers, and the District's previous isolation is being steadily eroded. There are already 17 forestry concessions, and strong indications that others, adjacent to the park itself, might be granted in coming years. A new paved highway from Belize City to Toledo is currently being completed, which the Government of Belize 
(GOB) hopes to extend eventually across the border into Guatemala. This will lead to a great increase in the volume of traffic passing through the Toledo District.

The GOB is setting up a parastatal body, the Toledo Development Corporation, to promote development of all land and resources in the region. In the light of these rapid changes currently affecting Toledo, it becomes ever more urgent to protect SarstoonTemash's natural resources for the benefit of local people and the country at large.

\section{Involvement of the indigenous peoples in the management and administration of STNP}

STNP was established in a period when developing countries were being strongly encouraged by the international community to adopt environmental protection measures in exchange for aid. Although the GOB created a number of new protected areas during this period, it did not establish the necessary institutional support to manage them effectively.

Resources allocated to the Ministry of Natural Resources (MNRE), whose Conservation Division (CD) is responsible for managing Belize's protected areas, were reduced by $30 \%$ in 1997 . At present, $\mathrm{CD}$ is being asked to oversee the management of $38 \%$ of Belizean territory that falls under some form of protected area status, with only three full-time staff. Faced with this task, both CD and MNRE have in recent years become very receptive to increased local involvement.

At first, the indigenous communities living adjacent to STNP were largely unaware of its existence. The government had never thought to consult the indigenous communities before creating the park; it neither established a permanent governmental presence in the area nor demarcated the park boundaries. So there was no reason for local people to suspect that they had been living on the border of a national park. By 1997, three years after the park's designation, community members had begun to hear about the park from governmental and media sources and decided to call a meeting to discuss the matter. Elected community leaders representing each village assembled in Barranco in February 1997. Initially, there was strong opposition to the park. Many perceived its creation as just another in a series of threats to their livelihoods and survival, and wanted to fight to dismantle it.

However, through discussions facilitated by a number of invited organisations, the community stakeholders were encouraged to explore the possibility of turning a negative situation to their advantage and pursuing a co-management resolution to their problem instead. Among the participating organisations were national indigenous organisations such as the Kekchi Council of Belize (KCB), the Toledo Alcaldes' Association (TAA) and the National Garifuna Council (NGC). Other groups present were the Belize Centre for Environmental Studies, the Protected Areas Conservation Trust (PACT), The Nature Conservancy and the United Nations Development Programme/Global Environment Facility(UNDP/GEF). A representative of CD was also asked to give a presentation on the characteristics of national parks. In the end. rather than seeking to de-gazette the park, community members decided to work collectively to secure a co-management agreement for the area with the GOB.

Considering the cultural and regional context, the indigenous communities' decision to fight for inclusion within the park management structure was ground-breaking. The indigenous participants had no formal resource management experience, nor any local 
examples of a successful indigenous/governmental co-management initiative to draw upon. However, with the input provided by the external representatives, the communities began to understand how the park could represent an opportunity for them to increase their income-generating opportunities by preserving, rather than exhausting, their natural resources.

The Barranco meeting was a significant and historic achievement, representing the first time in the Toledo District where communities of different ethnic groups agreed together to co-manage a protected area. This led eventually to the formation of a Steering Committee consisting of representatives from each village, as well as delegates from KCB, NGC, TAA, PACT and the Forestry Department, which would promote the communities' co-management aspirations. By June 1998, they secured the political support of all relevant government ministries for their co-management proposition.

With the assistance of the NGO EcoLogic Development Fund, the Steering Committee successfully obtained several small grants which were used to strengthen and formalise the community initiative. In 1998, the Environmental Social and Technical Assistance Program (ESTAP), a joint project of the Inter American Bank and the GOB, provided US $\$ 5,000$ to support consultations and training workshops in the five communities. In 1999, a grant from the International Fund for Agriculture Development (IFAD) of Rome, Italy, with co-funding provided by EcoLogic, enabled the Steering Committee to register the Sarstoon-Temash Institute of Indigenous Management (SATIIM) as a non-governmental organisation. The original Steering Committee was subsequently converted into the Board of Directors of SATIIM.

SATIIM is about to receive US $\$ 800,000$ from the World Bank/GEF over a three-year period. This will be used to develop a management plan for the park, to build an inventory of its biological resources, to record traditional ecological knowledge, and to strengthen both SATIIM and the communities' capacity to manage the park. In the meantime, SATIIM is seeking support for small, community-based income-generating activities so as to consolidate local support for the project's conservation and comanagement objectives.

\section{Traditional knowledge and practices}

Traditional knowledge and practices play an integral role in SATIIM's overall comanagement vision. SATIIM has ensured that the various biodiversity components identified in its proposal for co-management will be implemented through a careful integration of indigenous and scientific approaches to resource management. SATIIM puts a special emphasis on indigenous perspectives in the proposal, aiming to protect indigenous traditions and culture within the co-management system, and to demonstrate the major practical contribution that Kekchi and Garifuna traditional ecological knowledge can make to park management.

A primary role is envisaged for indigenous peoples in undertaking a comprehensive assessment of the park's resources. Technical staff will be hired to train communitybased para-biologists to record data on flora, fauna, soil characteristics and water quality conditions, both in the park and in the adjacent buffer zone. In the meantime, the project also intends to strengthen indigenous communal authority structures by giving Alcaldes the primary responsibility for enforcing park regulations within their respective villages, a move which should also help ensure greater compliance on the part of local indigenous communities with park regulations. 
Traditional slash-and-burn agriculture has to be banned in the park. SarstoonTemash's land is not ideally suited for agriculture and the communities have alternative lands for their milpa. The effects of this will be mitigated by the development of income-generating alternatives, such as organic cultivation projects in the buffer zones. Hunting is also illegal in the park; however, since the communities were never consulted before the creation of STNP, MNRE promised SATIIM that the non-extraction laws would be revisited when data on the park's wildlife have been collected. The incentive to protect animals within the park should increase once there is evidence that local wildlife can generate greater wealth for the indigenous communities through tourism.

\section{Critical evaluation of lessons learnt}

Although SATIIM's institutional progress has been steady, it has not necessarily always been smooth. While the five communities committed themselves in 1997 to seek co-management of Sarstoon-Temash, some pockets of local resistance to the project persisted for a while. Objections were based upon: (1) fear that a national park might force villagers to relinquish traditional rights to land within the park; (2) confusion about how the park would affect their subsistence resource use; and (3) doubts whether a co-management agreement could actually solve their livelihood crisis.

In order to address these concerns, SATIIM conducted a sensitive but determined educational campaign through regular workshops held in each of the five communities. SATIIM's efforts to link conservation with increased livelihood security in local indigenous perspectives have already met with success. Although access to the park is still not being monitored, the communities have independently begun to assume co-management responsibilities, imposing regulations of their own on their agricultural activities and use of resources in the park area. Community members frequently solicit SATIIM's help in locating the park's boundaries and seek advice on how to modify their extractive activities in order to respect those boundaries.

SATIM's Board of Directors is concerned that if funding for small income-generating activities is not soon secured, the community commitment to the project may ialter. Nevertheless, the strong support network that SATIIM has developed since 1997 gives good reason for optimism that financial support will be forthcoming. When it does, the financial requirements of the organisation itself and of the indigenous communities will both need to be met.

\section{Major challenges or directions for the future}

The most immediate challenge facing SATIIM is to prepare for the implementation of the co-management proposal. In the meantime, SATIIM will solicit funding for the small income-generating projects it plans to develop at community level ${ }^{4}$. The organisation has already secured the commitment of the Toledo Cacao Growers" Association (TCGA) and EcoLogic to develop an organic cacao project for the park"s buffer zone

4 SATIIM intends to seck these funds from a new joint IFAD Caribbean Development Bank project launched in Southern Belize in 2000, known as the Community-Initiated Agricultural and Resource Management Project, from the EcoLogic Development Fund, Protected Areas Conservation Trust, among other sources. 
area. The TCGA has considerable experience in training local indigenous communities to cultivate cacao and enjoys secure access to an international market for distribution.

EcoLogic will contribute its management expertise to the initiative and help obtain funding, while SATIIM will bring the communities onboard and oversee the project's implementation. SATIIM also intends to train indigenous peoples as tour guides and park wardens, and to help communities establish craft and visitor centres to generate both income and information about the park and the co-management initiative. More ideas for local income-generating projects will be developed in future in consultation with the five indigenous communities.

SATIIM recognises that it must address the communities' livelihood crises if their support for environmental conservation measures is to be guaranteed. Indigenous peoples are frequently marginalised from management initiatives, their traditional ecological knowledge undervalued, and their economic and cultural dependence upon the local environment overlooked. Sarstoon-Temash was itself created without any local knowledge or involvement. SATIIM aims to reverse this by showing how ecological, economic and cultural goals can be jointly met if indigenous peoples are given the responsibility of managing their traditional resources in partnership with outside support, and in an agreed framework.

\section{References}

Berkey, C. (1994). Maya land rights in Belize and the history of indian reservations. Report to the Toledo Maya Cultural Council.

Leventhal, R.M. (1997). Maya occupation and continuity in Toledo. Toledo Maya Cultural Council's Petition to the Inter-American Commission on Human Rights.

Zisman, S. (1989). The directory of protected areas and sites of nature conservation interest in Belize. Occasional Publication 10. Department of Geography, University of Edinburgh, UK.

Zisman, S. (Ed.) (1996). The directory of Belizean protected areas and sites of nature conservation interest. The Government of Belize, USAID, WWF and Winrock International for Agricultural Development. 186pp. 


\section{Case study 4}

\section{Wood Buffalo National Park, Canada}

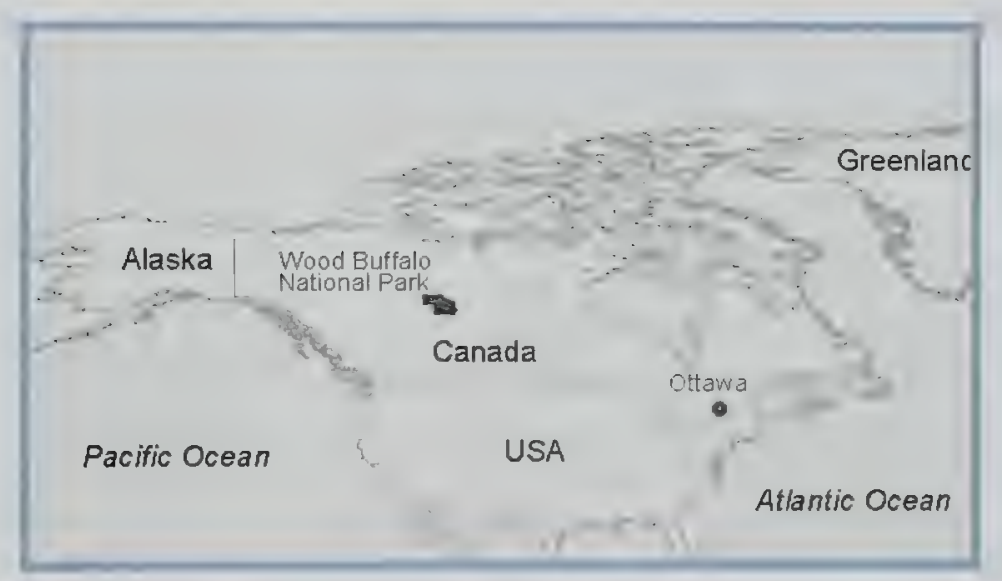





\section{Case study 4}

\section{Background information 5}

The Wood Buffalo National Park (WBNP) has a total land area of $44,807 \mathrm{~km}^{2}$. It contains huge tracts of boreal forest and plains, and some of the largest undisturbed grass and sedge meadows left in North America. The park is located on the boundary between Alberta and Northwest Territories. Its co-ordinates are $58^{\circ} 00^{\prime}-60^{\circ} 40^{\circ} \mathrm{N}, 111^{\circ} 00^{\circ}-115^{\circ} 30^{\prime} \mathrm{W}$.

WBNP comprises a vast wilderness area of the Northern Boreal Plains with four main topographic features: glacially eroded plateau; glaciated plains; a major freshwater delta formed by three major rivers; and alluvial river lowlands. The lowlands and floodplains of the Peace, Athabasca and Slave Rivers and the delta in Lake Athabasca exhibit classic fluvial land forms, with a complex series of meander scars, oxbow lakes and former river terraces, and good examples of birds-foot delta development. The uplands of the Birch and Caribou plateaus have been eroded by rivers to form long, incised gorges with extended stratigraphic cross-sections of bedrock and large alluvial fans.

The park protects representative examples of the Boreal Plains, Taiga Plains, Boreal Shield and Taiga Shield ecozones. The majority of the park is within the Boreal Plains and Taiga Plains ecozones, which is characterised by its flat topography. It is poorly drained, with elevations ranging from $210-300 \mathrm{~m}$ above sea level. The plain is underlain by Devonian period sedimentary bedrock (gypsum, halites, dolomite and limestone) and covered by glacial deposits of varying thickness. The boreal and taiga plains are a mosaic of muskeg, meandering streams, shallow lakes and bogs, and boreal forest.

Forests within WBNP consist of white spruce Picea glanca and black spruce $P$. mariana, jack pine Pinus banksiana and tamarack Larix laricana. Many watercourses have stands of balsam poplar Populus balsamifera and some uplands have nearly pure stands of aspen $P$. tremuloides. Lodgepole pine Pinus contorta occurs along the slopes of the Cretaceous plateau on the western edge of the park. The upper surface of the plateau is about $1,500 \mathrm{~m}$ above the rest of the park and supports a spruce-willow-birch upland tundra community. Some areas of prairie occur, with dominant grass species being Calamagrostis canadensis, Poa spp. and Carex spp., and the Peace-Athabasca Delta has flats with marshes of cat-tail Typha latifolia and sedges of Carex spp. Shrublands of willow Salix spp. and alder Almus sp. occur where wet marsh soils meet drier forest soils.

WBNP was created specifically to protect North American bison Bison bison, one of the largest free-roaming, self-regulating herds in existence. The herd numbered 10,000 in the early $1970 \mathrm{~s}$, declined to about 4,500 in 1987 . and currently numbers some 2.500 (Parks Canada, pers. comm., 1999). This is one of the few sites where the predator-prey relationship between wolves and bison still exists. A total of 46 other mammal species

5 Case study prepared by S.J.Nepal for WWF-I, with additions from Parks Canada 
have been recorded including black bear Ursus americanus, woodland caribou Rangifer tarandus caribou, moose Alces alces, grey wolf Canis lupus, lynx Lynx canadensis, snowshoe hare Lepus americanus, muskrat Ondatra zibethica, beaver Castor canadensis and mink Mustela vison. Occasionally animals more common to southern Canada are seen, such as red fox Vulpes vulpes, porcupine Erithizon dorsatum and white-tailed deer Odocoileus virginianus. The caves of karstlands provide hibernation sites for bats.

A total of 226 bird species have been recorded, including great grey owl Strix nebulosa and snowy owl Nyctea scandiaca, willow ptarmigan Lagopus lagopus, redpoll Acanthis spp., crossbill Lorix spp. and boreal chickadee Parus hudsonicus. This is the only breeding site of whooping crane Grus americana (EN), with 50 breeding pairs out of 188 individuals which summer in the park (Parks Canada, pers. comm., 2000). Protection and intensive management of this species in the park (and protection of their wintering ground in Texas), may have averted their extinction. There are few species of reptiles and amphibians but Canadian toad and red-sided garter snake reach their northern limits here. The fish fauna has been poorly studied, although there is a wide variety of aquatic habitats.

The site was declared as a national park, IUCN Management Category II, in 1922, and expanded in 1926 to its actual size. WBNP includes all except $230,000 \mathrm{ha}$ of the Whooping Crane Summer Range, and the Peace-Athabasca Delta, both of which were designated as Wetlands of International Importance under the Ramsar Convention in 1982. WBNP was inscribed on the World Heritage List in 1983. The park is under the jurisdiction of Parks Canada, a federal institution under the Department of Environment. The land inside the park is public (federal).

\section{Indigenous/Traditional people(s)}

Archaeological evidence shows that indigenous people have inhabited the Wood Buffalo region for more than 8,000 years, long before fur traders arrived in the early 1700 s. The Europeans called the people they met in this region Beaver, Slavey and Chipewyan. The Beaver and Slavey left the area as the fur trade moved west. Today, the communities around the park are mostly made up of Cree, Chipewyan, Metis and non-aboriginal people. Subsistence hunting, fishing and trapping still occur in WBNP, as they have for centuries, and commercial trapping continues as a legacy of the fur trade. Traditional use of certain park resources by local aboriginal groups is considered an important part of the park's cultural history.

WBNP is the only national park in Canada with a long standing tradition of native subsistence use and involvement. There are as many as 11 native groups with a varying level of interest in the park's resources. These include the Salt River First Nation, Smith's Landing First Nation, Fort Smith Metis Council, Mikisew Cree First Nation, Athabasca Chipewyan First Nation, Fort Chipewyan Metis Council, Little Red River Cree First Nation, Hay River Metis Council, Hay River Dene Band, Deninu K'Ue First Nation and Fort Resolution Metis Council. While there is a certain homogeneity of interest, it would be wrong to assume that all these groups and organisations share common goals and aspirations just because they are of aboriginal descent.

Indigenous groups in and around WBNP. as elsewhere in Canada, have evolved from a traditional lifestyle which included hunting, trapping, fishing and the seasonal 
collection of edible plants and berries. Although the sustainability of wildlife and its habitat is still important to these groups, their concern for wildlife goes far beyond its food and economic value. Aboriginal people have a holistic view of the world and see man as one element, along with animals, trees and other natural features.

To aboriginal people, wilderness, in the sense of areas completely devoid of human habitation, does not exist as even the most wild and remote areas in Canada are dotted with graves and habitation sites. The mountains and hills, lakes and streams, trails and portages all have names, stories or legends associated with them. At the core of this symbiotic relationship with nature is a reciprocal connection with the plant and animal world. Thus, in many ways, the wilderness ethic of the indigenous societies and conservationists are not very different. For both, an eagle is worthy of respect and love both for its innate beauty and for its connections with the thunderbird of native legend (Morrison, 1997).

Today, indigenous leaders in Canada insist that native peoples "have a keen interest in preserving areas as close as possible as to their original state" (Erasmus, 1989 cited in Morrison, 1997). Without renewable resources to harvest, native people lose both their livelihood and their culture. Recently, however, indigenous resource management practices have come under heavy criticism from mainstream groups, who believe that wildlife hunting and fishing are no longer sustainable. Two reasons are given for this argument: first, because of the rapid population growth among many native communities; and secondly because hunting and fishing practices now often use modern technologies such as outboard nıtors, snow mobiles and all terrain vehicles. Though this has resulted in a tendency to overexploit available resources, indigenous methods and wildlife harvest levels may well be far more sustainable than those used by non-native societies.

Indigenous communities have, so far, refrained from directly responding to questions of over-harvesting and have tended to concentrate their attention on issues of land title and treaty and aboriginal rights. Their experience with the creation of parks and protected areas, and with the enforcement of hunting and fishing regulations, has also made many of them deeply sceptical of the goals and motives of both government and the conservation movement generally. Indeed, until recently, few park government staff appreciated the value of traditional harvesting practices and the positive contribution they could make to modern park management.

During the 1980s and early 1990s, Canada witnessed increasing empowerment of indigenous communities, brought about by several interconnected developments. These stemmed not just from constitutional developments but court decisions, government policy changes, the politicisation of indigenous communities and the land claims process. As a result, aboriginal communities have had more opportunities to determine their future in terms of what is legally possible, economically feasible, socially acceptable and culturally appropriate (Notzke, 1994). For example, indigenous involvement in protected area management is now encouraged and there are many cases of co-management projects involving protected area authorities and groups of indigenous peoples.

However, there are still conflicts between the government authorities and native communities in Canada. Although native land claims and treaty rights are now common to every province in Canada, the claiming of "occupied" and "unoccupied" land is still subject to intense debate and negotiation and, in some cases, court adjudication. In 
addition to issues of land title, aboriginal land use itself has also become a controversial subject. There are, for example, mainstream conservationists who think that native land use and resource management practices are not sustainable and have put pressure on government to control and regulate the harvesting practices of both native and nonnative communities. To them, native harvesting rights are undemocratic because they confer special privileges on one group of people. This opinion is widely shared by non-native people in rural and remote areas of Canada (Morrison, 1997).

\section{Involvement of the indigenous peoples in the management and administration of WBNP}

During the first 50 years of its existence, government officials managed WBNP according to what they perceived as the best interests of indigenous peoples. Rules and regulations about who could or could not hunt or trap in the park were made with little consultation with the native population and enforced without much consideration of traditional harvesting practices. The management was centrally controlled and regulated, and fostered distrust and cynicism among the native peoples: such attitudes continue to this day, though to a lesser degree (East, 1986 cited in Notzke, 1994).

A prominent instance of conflict over resource management in WBNP is the Northern-Diseased Bison Issue. Around 30 to 50 percent of the wood bison in the park are reported to be infected with bovine brucellosis and tuberculosis: as a result, there is pressure from Agriculture Canada and some wildlife managers to destroy the entire herd. Also, cattle ranchers outside the park boundary fear that their cattle may be infected too, especially when bison migrate out of the south west of the park in Alberta. Currently, there is no treatment or effective vaccine for either disease in bison and cattle.

The Northern-Diseased Bison Assessment Panel, formed in 1989-90 under the Federal Environmental Assessment Review Office (FEARO), recommended that all diseased bison be exterminated and replaced with bison from Elk Island National Park. This total eradication plan was vehemently opposed by aboriginal groups, environmentalists and other concerned organisations and private citizens who thought that the government was less concerned about the welfare of the disease-free herd than it was about the encroaching domestic cattle and the economic welfare of the cattle ranchers. They feared that the programme would have a profound impact on their domestic economy, which includes the bison, and on the ecology of the area particularly on the wolf population, which could be expected to resort to killing more moose and scavenging traplines in the absence of its accustomed prey of bison (Notzke, 1994).

This opposition resulted in a new plan to "test and slaughter" infected bison, which was formulated after consultation between the federal Departments of Environment and Agriculture and local native people. According to the new procedure, bison would be rounded up, tested for tuberculosis and brucellosis, and slaughtered if tested positive (Notzke, 1994). Indigenous people who customarily hunt bison on the periphery of WBNP would be directly involved in the entire process. Although this plan was also controversial and opposed by many conservationists, at least it was a better alternative.

Another important issue is that of hunting and trapping privileges. WBNP is the only example of a Canadian national park where traditional harvesting by native people was 
taken into account. The establishment of WBNP brought the first departure from the traditional policy of excluding indigenous peoples from park management. An exemption to the National Parks Game Regulations authorised the Superintendent of WBNP to issue permits to "Treaty Indians" who had hunted and trapped in the area before the creation of the park. A number of non-native groups who had previously hunted and trapped there were granted similar rights (Hunt, 1979 cited in Notzke, 1994).

Until 1963, the park was managed by the Northern Affairs arm of the Department of Indian Affairs and Northern Development. Its mandate was unclear: although the management regime was targeted ostensibly towards preservation it was also geared towards economic development and native interests. In 1964 the National Parks Branch assumed authority for WBNP, and sought to reconcile conservation and economic development.

As a result, East (1991) claimed that WBNP was a good example of co-management between government and native representatives, with the native hunters and trappers involved in resource management decisions. He pointed in particular to the Northern Buffalo Management Board (NBMB) which operated from June 1991 to December 1992. This was formed by the Federal Government in response to an Environment Assessment Panel which recommended specific measures to deal with the cause and effects of diseased bison in WBNP. The Board was made up of federal, territorial and aboriginal community representatives who worked together to try and produce a consensual approach to dealing with some of the park's bison health problems. The aim was to prevent the spread of disease and ensure a healthy, free-roaming buffalo population with the present genetic diversity. Data collection used both traditional knowledge and scientific methods. Overall, the strategy aimed to reflect an ecosystem approach, which considered disease, prey-predator relationships, and threats to habitats (Notzke, 1994). After approximately 18 months of work and the completion of severall reports, the Board was dissolved. During its existence, the Board incorporated the participation of nine aboriginal communities surrounding the park who received funding "to enable them to develop plans, identify traditional and scientific knowledge gaps..." and meet other objectives. Essentially each community produced a community plan of how it wanted to deal with the bison disease issue in and near WBNP.

The NBMB experience is a valuable lesson for a number of reasons. It demonstrated the complexity (multiple issues and a diverse mix of aboriginal and government interests) and the cost $(\$ 1.4 \mathrm{~m}$ was spent by the federal government in funding the initiative) of attempting to resolve a difficult issue like bison health through the participation of federal, territorial and community/aboriginal levels of government. Ultimately the initiative was not a success and a major reason was the struggle for control of the process between aboriginal groups and the federal government. Furthermore, given that it was only operational for less than two years, the costs were considerable and this is a timely reminder of the cost of structured participation by every community around the national park.

\section{Critical evaluation of lessons learnt}

In the course of efforts which have been made - and are still ongoing - by the park authorities to resolve the issue of native rights in WBNP, several challenges have emerged: 
ह The failure to agree on a practical (and durable) definition of "consultation". The government considers it as seeking a range of opinions to be taken account of when decisions are made: the native peoples considered it to be a process of seeking direction for implementation. To the indigenous communities, therefore, consultation was thought to have failed if their advice was not acted upon;

(6) The diversity of interests represented by the many stakeholders. The size of WBNP, the number of different communities in and around it, and the number of different native organisations mean that many organisations have an interest in aboriginal involvement in management decisions, and that it has been difficult to arrive at a workable consensus;

The complexity of issues over which agreement is sought. Several native community representatives claim that the many rules and regulations which govern the management of a national park make it difficult to accomplish firm goals and objectives. While the holistic management approach adopted in the WBNP is appropriate, agreement is often hard to achieve because the issues are so contentious and complex;

Finally, a long time frame is needed to reach agreement, and resolve problems. This too leads to dissatisfaction and frustration among some key stakeholders, and leaves open the possibility that conflicts will continue to arise in future.

\section{Major challenges or directions for the future}

Involving indigenous peoples in park management in the Canadian context means appreciating their values, ethics and attitudes towards nature and incorporating these values into national policies and agendas. At the core of the issue are the wilderness ethic and differing concepts of nature between the native and mainstream societies. Many people in mainstream society have a romanticised view of the national parks, seeing them as devoid of human habitation: places which people may visit for recreation and enjoyment but where there should be no permanent residents or occupants. In contrast, indigenous societies place humankind at the centre of the natural world - subordinate to the whole, but an essential part of it. This, in essence, is the dilemma facing WBNP.

But there is some cause for optimism. WBNP demonstrates that partnership is possible if all parties come to the negotiating table at the outset, no matter how contentious are the issues or how divergent the approaches to wildlife management. There is also increasing recognition in society at large that traditional methods of resource management can be sustainable, and this is reflected in recent government policies.

\section{References}

East, K. (1986). Resource co-management in Wood Buffalo National Park: the National Parks's perspective. In: Native people and renewable resource management. Symposium of the Alberta Society of Professional Biologists (ASPB). ASPB, Edmonton, Canada. Pp.86-95. 
East, K. (1991). Joint management of Canada's northern national parks. In: West, P.C. and Brechin, S.R. (Eds.) Resident peoples and national parks. Social dilemmas and strategies in international conservation. University of Arizona Press, Tucson, USA. Pp.333-345.

Erasmus, G. (1989). A native viewpoint. In: Hummel, M. (Ed.) Endangered species: the future for Canada's wilderness. Key Brother Books, Toronto, Canada.

Hunt, C.D. (1979). People and parks: selected legal issues in Canada. In: Nelson J.G., Needham, R.D., Nelson, S.H. and Scace, R.C. (Eds.) The Canadian national parks: today and tomorrow. Conference II: Ten Years Later. October 8-13, 1978. University of Waterloo, Canada. Pp.605-624.

Morrison, J. (1997). Protected areas, conservationists, and aboriginal interests in Canada. In: Ghimire, K. and Pimbert, P.M. (Eds.) Social change and conservation. Environmental politics and impacts of national parks and protected areas. Pp.270-296.

Notzke, C. (1994). Aboriginal peoples and natural resources in Canada. Captus Press Inc., North York, Ontario, Canada.

Parks Canada (1999). Website information. http://parkscanada.pch.gc.ca/.

Nepal, S.K. and Weber, K.E. (1993). Struggle for existence: park-people conflict in the Royal Chitwan National Park. Asian Institute of Technology, Bangkok, Thailand. 



\section{Case study 5}

\section{The Lapponian Area, Sweden}

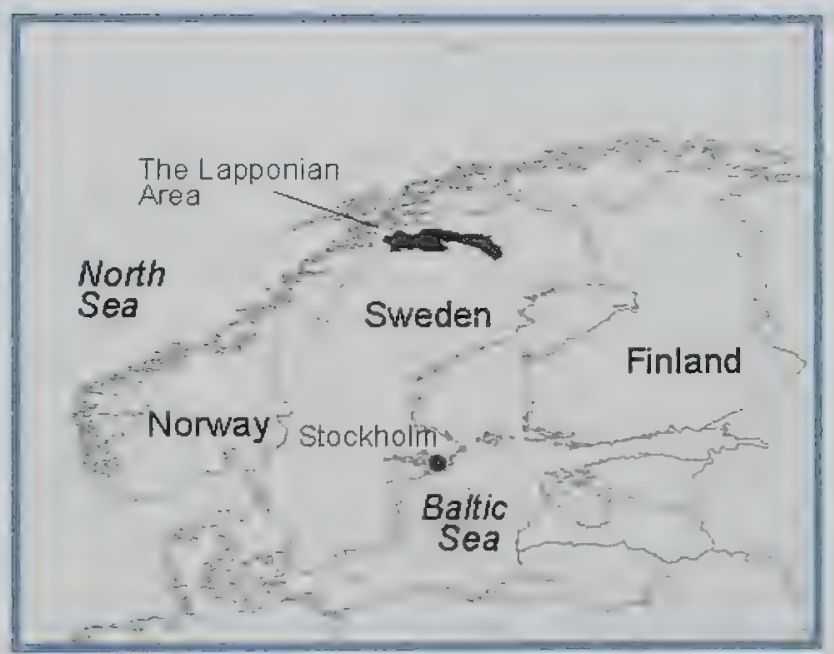





\section{Case study 5}

\section{Background information ${ }^{6}$}

The Lapponian Area (LAPP) covers almost $9,400 \mathrm{~km}^{2}$ and lies in Norrbotten county, in the circumpolar zone of northern Sweden. It stretches from the centre of the county over the mountain range to the west, as far as the Norwegian border. LAPP comprises the municipalities of Gollivare, Jokkmokk and Arjeplog and the major town is Kiruna, to the north-east. Its coordinates are $66^{\circ} 50^{\prime}-67^{\circ} 48^{\prime} \mathrm{N}, 16^{\circ} 05^{\prime}-20^{\circ} 25^{\prime} \mathrm{E}$.

LAPP contains two landscape types: an eastern lowland area of Archaean geological origin, and a western mountainous landscape, covering two-thirds of the area. The former was created more recently and comprises part of the Swedish-Norwegian Scandes. It consists of a monadnock plain, that is a wide plain, with isolated low, conical hills, covered by taiga vegetation and lak.es. Glacial activity has had a major influence on the development of the second landscape type, which is characterised by high, steep mountains, deep valleys and powerful rivers. It contains more than 200 peaks over $1,800 \mathrm{~m}$ and some 100 glaciers.

The whole area comprises entire river systems, such as those of the Vuojatätno, Rapaätno and Muddusjokk rivers and the Rapa River Delta in the Laitaure Lake. It includes notable geological features such as deep canyons, or "kursu" valleys, with nearly vertical walls over $100 \mathrm{~m}$ in height cut by melt water, sandurs (outwash plains), boulder hollows, tundra polygons, U-valleys, glacial cirques and moraines, talus accumulations, drumlins, weathering phenomena and bogs.

Current flora and fauna have colonised the area following the last glacial retreat 9,000 years ago. Pristine pine and fir forests cover approximately 100,000 ha and a variety of swamp types cover another 100,000 ha, the latter being the largest untouched mire complex in Western Europe. Botanically, this is one of the most interesting mountainous regions of Sweden, containing a rich alpine flora. The Padjelanta alpine meadows, and particularly Jeknaffo mountain, support scarce species such as Potentilla hypartica and the rare Arenaria humifusa. The lowland (taiga) in the east comprises a plain with flat-topped hills covered by taiga vegetation with large open areas. The oldest trees are in the pine forests of Muddus and are about 700 years old.

Several animal species of conservation interest have been recorded from the region. including wolverine Gulo gulo (VU), European otter Lutra lutra and white-tailed cagle Haliaeetus albicilla (NT). Other species present are brown bear Ursus arctos, lynx Felis lynx, Arctic fox Alopes lagopus, magnificent moose Alces alces, golden eagle Aquila chrysaetos, whooper swan Cygnus cygmus, gyrfalcon Falco rusticulus and peregrine falcon Falco peregrinus. The bog surrounding the central lake in Muddus, Muddusjaure, supports a great variety of birds. Accordingly, a large area has been set aside as a bird 
sanctuary, with entry prohibited. In the Sjaunja mires, more than 150 bird species have been observed, at least 100 of which have been confirmed as breeding.

LAPP includes four national parks established under the provisions of the 1909 Nature Protection Act: Sarek National Park and Stora Sjöfallet National Park (1909), Muddus National Park (1941) and Padjelanta National Park (1962) (Sarek and Stora Sjöfallet are among the oldest national parks in Europe). There are also two nature reserves established under the provisions of the 1964 Nature Conservation Act: Sjaunja (1986) and Stubba (1988). In total, $95 \%$ of the site is protected as national park or nature reserve. In addition, the site contains the Sulitema Glacier area, the Rapa Valley Delta and the Tjuolta Valley, these being protected under the 1987 Natural Resources Act. The area contains two wetlands of international importance recognised under the Convention on Wetlands of International Importance (Ramsar Convention): $1,886 \mathrm{~km}^{2}$ of mire complex in the Sjaunja Nature Reserve, and the Rapa Valley Delta in Sarek National Park. Sarek, Padjelanta and Muddus national parks were awarded the Council of Europe's European Diploma, Category A in 1967, and this has been renewed every five years since. Lapponia was inscribed as a mixed natural/cultural World Heritage property in 1996 (Swedish Environmental Protection Agency, 1997). Approximately $99 \%$ of the land is owned by the State; the rest is private.

\section{Indigenous/Traditional people(s)}

LAPP is inhabited by the Saami people, who arrived in the area 4,000 to 5,000 years ago. Their global distribution extends from northern parts of Norway, Finland, and Sweden to the Kola Peninsula in Russia. The entire territory occupied by the people is known by the Saami as Sápmi. In Sweden there is a population of 17,000 Saami. Within LAPP, there are 200-250 Saami, with herds of 30-35,000 reindeer Rangifer tarandus.

The earliest written record of the Saami dates back to Tacitus' account in 98 AD of a people whom he called "fenni". In the 6th century, the Greek historian, Procopius, referred to certain inhabitants of Scandinavia as "skridfinns". Paulus Diaconus in 750 describes the "skridfinns" as hunters and skiers who kept animals resembling deer. The writings of Ottar provide some of the richest history on the Saami. Ottar owned 800 domesticated reindeer, but his main source of livelihood was collecting taxes from the Saami. In 1673, Johannes Schefferus wrote about the life of the Saami in Lapponia.

For thousands of years, the Saami lived mainly by hunting wild reindeer for fur and food. It was not until the 16 th century that the reindeer could be said to have become semi-domesticated. Herders led nomadic lifestyles, following the reindeers' annual grazing cycles. Summer was spent in the mountains and winter in the needle-leaved forests in the east. Communities were organised into siidas, which performed an essential territorial as well as a social and cultural function.

During the Middle Ages, the Nordic states tussled for control over the Saami regions. At times, the Saami paid taxes to several states simultaneously. These disputes finally came to an end in 1826. During this time the Saami were thought of as pagans by their colonising states. Attempts to evangelise them may have begun as early as the 12 th century when churches began to appear in the region. Settlers from outside the area began arriving in the 1600 s and 1700 s to set up permanent farmsteads, and Christian missionary work began in earnest in the 18 th century. 
Since the middle of the 20th century, reindeer husbandry has been transformed. Small-scale systems have been replaced by larger and less closely-supervised herds. The use of reindeer as draught animals and providers of milk has declined. Herdsmen now travel by modern motorised transport. A small proportion of Saami families still carry out migrations and maintain summer residence in small cabins (which have replaced traditional goahtes or cots) in the mountains. The majority, however, follow a sedentary form of reindeer husbandry and live in villages. Likewise their environment has changed with the development of modern forestry, agriculture and other industries in the region. In some areas a significant amount of winter grazing lands for Saami reindeer have disappeared.

Saami are legally permitted to herd reindeer over private and state land covering an area of $160,000 \mathrm{~km}^{2}$ in the northern mountains. In LAPP, reindeer-herding is organised into seven reindeer husbandry districts, or Saami villages, six located in the mountains (Mellanbyn, Sorkaitum, Sirkas, Jakkakaska, Tuorpon and Luokta-Mavas) and one located in the forest (Gollivare). The taiga is uninhabited, although reindeer owners live in surrounding villages. No part of the World Heritage Site is occupied year round.

The Finno-Ugric language represents an important part of Saami culture. Amongst the different forms and dialects, there are three distinct languages: East Saami, Central Saami and South Saami. Their use has generally declined over the past 100 years (Swedish Institute, 1990).

A number of traditional Saami song styles exist, including joik, lavlu/laavloe and vuelie. Joik is often compared to Amerindian chanting, and is an attempt to sing the essence of the subject. It is highly personal and spiritual. Laavloe has words or lyrics, whereas a vuelie consists of a story about a person or an event and may incorporate chanting without words. Traditional instruments include the bullroarer, a horn of wood with a string attached, which is played by circling it round the head, and the flute. Interest in these traditional singing styles has recently revived.

The Saami religion has been largely extinguished by conversion to Christianity. It contained many gods who steered the powers of nature in differing ways. The will of these gods was interpreted by Saami shaman, called Noaid, usually using a drum decorated with symbolic images.

The Saami's language, traditional clothing, handicraft, and music, are distinctively different from those of other ethnic groups in Scandinavia. However, their strong reliance on reindeer husbandry and, in some cases, nomadic lifestyles are considered central to their identity to the outside world. These are the aspects of Saami identity that have been incorporated into Swedish law.

\section{The Saami involvement in the management of the Lapponian Area}

According to the Swedish Nature Conservation Act, national parks lie on state-owned land and consist of untouched areas representing different types of Swedish landscape with access for outdoor recreational purposes. Each national park has special regulations. Nature reserves represent a more flexible form of protection which can vary in character, size and purpose, and can be located either on privately or publicly owned land. 
The responsible national body for management of LAPP is the Swedish Environmental Protection Agency, which funds, supervises and compiles management plans for the national parks. The County Administration of Norrbotten provides general administration, supervision and implements the management plans. Field management is handled by its Mountain Branch at Jokkmokk.

The Saami people's rights are legally protected. The first law dates from 1886 . The present Reindeer Husbandry Act of 1971 provides unique rights to land, water, hunting and fishing, and includes the use of motor vehicles. However, the Act extends only to those Saami who breed reindeer, of which there are 2,000 out of the total Saami population of 17,000 .

All reindeer-breeders belong to a Saami village, which represents an administrative and economic unit, a remnant of the historical siida. The members decide how herds are to be managed within the confines of the Reindeer Husbandry Act, which sets a maximum allowance of reindeer of 280,000 for all Sweden. The Saami village can also decide how many reindeer each of their individual members is allowed to keep.

A new rule (1993) in the Reindeer Management Act enables more effective monitoring of reindeer and their effects on vegetation. The Board of Agriculture is responsible for making an assessment of winter grazing resources, on which a quota of reindeer numbers is based. In addition, Government subsidies to reindeer herdsman are based on kilograms of meat rather than numbers of animals, a criterion which beneĩits owners of well-nourished animals rather than those of large, but under-nourished herds.

Research initiatives are often undertaken in partnership with indigenous peoples. In 1999, a workshop took place on the "Human role in reindeer/caribou systems", where a large number of reindeer herding representatives were brought together with natural and social scientists to discuss research needs, Arctic policy and scientific methodology.

\section{Traditional knowledge and practices}

Fishing is important during summer months. Commercial fishing takes place in the large lakes in Padjelanta. Fresh fish are transported by air to be sold in the east. Saami have the right to fish and hunt in appropriate seasons within reindeer husbandry areas. Moose (Saami only), pine marten, red fox, arctic hare, willow grouse, ptarmigan and capercaillie are permitted game. Some large carnivores and eagles are protected, except where animals are attacking herds of reindeer. Hunting of bear, lynx, wolverine and wolf is permitted outside the national parks if it is necessary for reindeer herding. The most frequently hunted game are moose and willow grouse (Swedish Environmental Protection Agency, 1995).

At Staluluokta in Padjelanta National Park there is a sacred place where reindeer were sacrificed. A large cave at the base of Skierfe in the Laitaure Delta, the symmetrical peak, Slugga, the promontory Passåive and the Akka massif are all sites of cultural or religious significance.

\section{Critical evaluation of lessons learnt}

Grazing and trampling by reindeer, use of motorised vehicles, building of cabins and fences, hunting and fishing all have an impact on the landscape and biodiversity. The 
effect of reindeer on lichen populations, their winter forage, has been particularly noted (Swedish Environmental Protection Agency, 1995). More effective monitoring of changes in vegetation is now a part of the Swedish Environmental Protection Agency's national programme.

The Saami are aggrieved over incursions into their customary rights. Problems have arisen, for example, over the granting of small game hunting licences to non-Saami, the competing use made of traditional grazing areas which are also privately owned forests or in agricultural zones, and levels of predator populations. The situation of non-herding Saami, whose rights are not supported by the Reindeer Husbandry Act, is also a cause for concern.

Some of the most prominent conflicts are between Saami herders and the owners of private forest to the south of LAPP, who demand compensation for damage caused by reindeer browsing in the winter. The conflict does not extend to the larger forest estates or state-owned forest, where the rights of the Saami to herd reindeer in the forest are recognised. The cases that have reached court have been found in favour of the private landowners.

Such disputes bring into question the legal status of Saami rights and the standing of the Reindeer Husbandry Act. A report, commissioned by the Swedish cabinet in 1989 , revealed the shortcomings of the Act and recommended that it should be strengthened to support the legal position of the Saami (Swedish Institute, 1990). In addition, a Saami parliament has been created in each of the Nordic countries in order to provide stronger representation of Saami interests. In Sweden, the Saamiting was inaugurated in 1993, but its powers are limited and it serves chiefly as an administrative body.

\section{Major challenges or directions for the future}

The status of the traditional rights of the Saami may be better upheld within LAPP than elsewhere in Sweden, since they have not been challenged in court by private landowners. Existing rights focus on regulating reindeer hustandry rather than maintaining the cultural and community identity of the Sami people.

\section{References}

Swedish Environmental Protection Agency (1995). World Heritage Convention, Natural Heritage: Sweden, The Lapponian World Heritage Area. Precious Nature-Saami Culture. Proposal for World Heritage Nomination prepared by the Swedish Environmental Protection Agency. 25pp.

Swedish Environmental Protection Agency (1997). The Lapponian area. A Swedish World Heritage Site. Swedish Environmental Protection Agency, Stockholm. 48pp. Swedish Institute (1990). The Saami people in Sieden. Swedish Institute, Stockholm. $4 \mathrm{pp}$. 



\section{Case study 6}

\section{Simen Mountain National Park, Ethiopia}

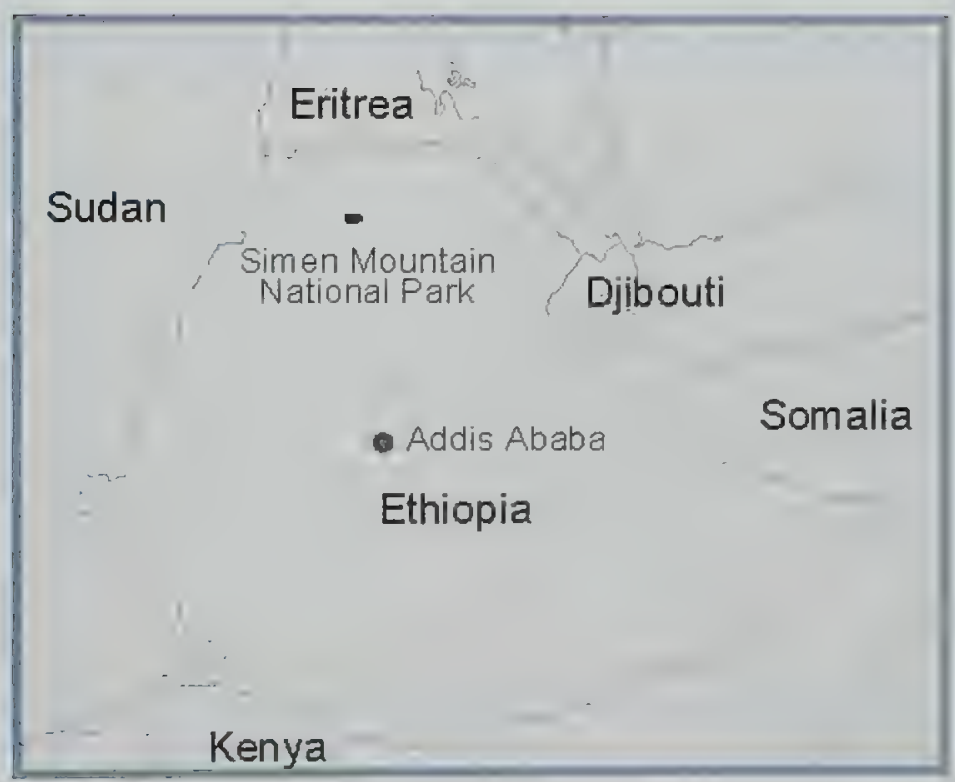





\section{Case study 6}

\section{Background information 7}

The Simen Mountain National Park (SMNP) is located in the western Simen Mountains, $120 \mathrm{~km}$ north-east of Gondar in Begemder Province, north-west Ethiopia. The town of Adi Ark'ay lies to the north, Debark to the south-west and Deresge to the south east. The coordinates at the central point are $13^{\circ} 11^{\prime} \mathrm{N}, 38^{\circ} 04^{\prime} \mathrm{E}$.

With a total land area of $136 \mathrm{~km}^{2}$, SMNP occupies a broad undulating plateau of vast, grassy plains bordering the northern edge of the Ethiopian Amhara plateau. The area is part of the Simen Massif which includes the highest peak in Ethiopia, Ras Dashan Terara $(4,620 \mathrm{~m})$. The massif was formed some 25 million years ago and the igneous basalts have since been eroded to form precipitous cliffs and deep gorges. Some cliffs reach $1,500 \mathrm{~m}$ in height and extend for long distances (the north scarp extends $35 \mathrm{~km}$ ). The plateau is bounded on the south and north-east by the deep valleys of the Tacazze River and its tributaries. It is bisected from north to south by the Mayshasha River, for which it is the principal catchment area.

Within Ethiopia, Simen forms a contact zone between the Palearctic region in the north and the Ethiopian region in the south. It contains representative flora and fauna from both regions. The flora consists of a mixture of Afro-Alpine woods, heath forest, high montane vegetation, montane savanna and montane moorland with tree heath Erica arborea, giant lobelia Lobelia whynchopetalum, Solanum sp., Rosa abyssinica, everlastings Helichrysum spp. and mosses (Grimmiaceae). Ridge tops and gorge sides support coarse grassland with herbs Thymus spp., Trifolium spp., Geranium arahicum, thickets of Rumex nervosus, scattered Otostegia minucci, and creepers Clematis simensis and Galium spurium. Forests of St. John's wort Hypericum spp. once flourished at $3,000-3,800 \mathrm{~m}$, but few still remain. There are high, but unquantified, levels of endemism (Hurni, 1986).

Walia ibex Capra walie (CR) on the north scarp of the massif is endemic to Simen Mountain, with most of the population occurring in the park. Numbers in 1989 were estimated at 400 individuals, decreasing to 250 in 1996 (Shackleton, 1997; Nievergelt. 1996). Simen fox Canis simensis (CR) is endemic to Ethiopia (Sillero and Macdonald. 1997, cited in Hurni and Ludi, 2000). Other mammals include gelada baboon Theropithecus gelada (NT), leopard Panthera pardus, caracal Felis caracal, spotted hyena Crocuta crocuta, and several large herbivores including bushbuck Tragelaphus scriptus, common duiker Sylvicapra grimmia and klipspringer Oreotragus oreorragus. The 400 bird species include lammergeier Gypaetus barbanus, Verreaux's cagle fquilu verreauxii, kestrel Falco timmunculus, lanner falcon F. hiarinicus, and augur buzzard Buteo rufofuscus.

7 Information compiled and summarised by S.J. Nepal from Hurni and Ludi (2000) 
The area was designated as a National Park, IUCN Management Category II, by Order No. 59 of 31 October 1969. Boundary changes were proposed in 1983 to exclude some cultivated land in Wazla Valley and to include Bwahit Mountain summit. It was inscribed on the World Heritage List in 1978, and was put on the List of World Heritage in Danger in 1996. Until the summer of 1996, the park was managed by the Ethiopian Wildlife Conservation Organization (EWCO), a department of the Ministry of Natural Resources Development and Environmental Protection. As part of the on-going political and administrative reforms, the responsibility for SMNP was transferred to the Amhara Region.

Development of tourism is still in its early stages. In 1995, there were just over 700 tourists, increasing from 172 in 1993. Given the poor infrastructure, and lack of adequate tourist services and facilities, it is unlikely that SMNP will see more than 3,000 tourists per year.

\section{Indigenous/Traditional people(s)}

Owing to the favourable agro-ecological conditions, the surrounding region of SMNP has been densely populated. The population of the Simen Mountains belongs to the Amhara ethnic group. In the lowlands north of Adi Ark'ay, there are Tigrinva people and to the east below the escarpment in Beyeda, there are Agaw people of Wag. The Amhara are part of the Semitic-speaking population of Ethiopia. They are mainly sedentary agriculturalists with a mixed farming system based on crop cultivation complemented by a strong livestock component. The Amhara are a minority (about 30\%) in present-day Ethiopia and have been brought under one single administrative unit, Region Three, as a National Regional State in 1993.

When SMNP was gazetted in 1969, it included significant portions of settlements and agricultural land of small-scale peasants who had been there for many generations. Today, eight Kebele Associations (KA) or communities, namely Mindigebsa and Adisge, Abergina, Ambaras/Jona and Argin, and Lori in the highlands, and Adebabay, Agidamiya, Kabena and Sera Gudela, and Angwa and Kernejan in the lowlands, have parts or all of their territory within the national park. Altogether, there are 30 villages, of which two are completely located inside the park boundary. Almost 5,000 households, with a total population of about 28,000 , live in and around SMNP. Some 10,000 people either live on, or use land and other resources inside the park. Over the past 30 years, the population is estimated to have increased by two percent per year. Similarly, the total livestock population is also reported to have increased significantly, with increased grazing intensity.

Subsistence agriculture is the dominant economic activity. The farming system involves complex linkages between crop production and livestock rearing. Poverty is widespread and many villages suffer from food shortages. There is very little infrastructure, and access to basic health and education is very limited. The region was closed to development for over 17 years because of war and insecurity.

In the past, expansion of cultivated land had reduced the forest cover a great extent. Today, there is virtually no possibility of expanding agricultural land as remaining potential areas are now inaccessible and/or are within the national park boundary. It is estimated that the average land holding size is $5.2 \mathrm{ha}$ per household; however, there are significant differences between villages. Since agricultural land is now limited, but 
human population is still growing, the only way to to meet the household food demands is to shorten or even abandon fallow periods. This has diminished soil productivity, and soil degradation is very pronounced in the entire region. However, the tradition of farm-tree and other land use practices has led to suggestions that many tree and shrub species in the Simen area can be bred and cultivated for agro-forestry, soil fertility enhancement, as sources for fruits and nuts, and as hosts for honey production.

Ethiopia has a centralised system of government, which rarely includes local involvement and local decision-making in resource management. Recently, decentralisation reforms have been made, but these merely transfer State power from the centre to peripheral institutions. There has not been any real transfer of power from the top to the bottom. Due to more than 17 years of war and violence, suspicion between the government and indigenous communities has led to a breakdown in communication and understanding around the issue of natural resource utilisation and management. In the context of protected areas, the policy of securing strictly protected wildlife habitats (in national parks) has precluded local participation in protected area management.

\section{Involvement of the indigenous peoples in the management and administration of SMNP}

In the context of SMNP, the main stakeholders are resident land users, staff of the park at central, regional and local levels, international development agencies, tourism facilitators and tourists. There are cases of conflict involving each of these stakeholders. As the region is characterised by subsistence agriculture, people depend on forest products taken from inside the park. SMNP is seen by the government as a means to implement protection of park resources, while local inhabitants consider the park as a threat to their existence. Moreover, in 1978, a large number of inhabitants from villages both in the vicinity and inside the park were expelled. Although they were able to return eight years later, local attitudes towards park management remain negative.

On the one hand, local people hope to profit from job opportunities and tourism; on the other, the park is seen as a hindrance in many respects:

a it is impossible to extend agricultural land without encountering the rules and regulations of the park;

- since all remaining forests are within the park boundary, cutting trees for firewood and construction timber runs up against the law (the rules are not at present enforced strictly, but people are aware that this might change in the future);

․ wild animals from the park are reported to have destroyed agricultural crops and killed domestic cattle. Trapping and shooting is strictly forbidden, which is one reason why local attitudes towards wild animals, particularly prey species such as hyena, are not favourable. Protecting crops from wild animals puts an extra burden and stress on farmers;

there remains a threat of resettlement of resident land users inside the park. As long as this remains a possibility, attitudes towards the SMNP management are likely to be hostile.

Conflicts are also related to infrastructure improvement, particularly concerning a road project through SMNP. At present, only one road connects Debark (the location for 
the park headquarters) with other villages and the park. A proposal for road improvement was put forward, and the United Nations Capital Development Fund (UNCDF) signalled its willingness to provide the funding. However, there were disagreements between the regional Administration, EWCO and tourism experts concerning the alignment of the road. Concerns were also raised by nature conservationists about possible negative impacts of the road on wildlife, forest use, and the possibility for immigration and poaching. The project was delayed and UNCDF did not commit funds. However, the regional road authority constructed the road, though lacking trained manpower and funding. As a result, the road was aligned to avoid the need for bridges and passed through previously undisturbed highland Erica-Hypericum forest, thus posing a big threat to the biodiversity of the area, particularly to a corridor for Walya ibex between important habitats.

Another conflict relates to the aspirations of resident land users and the SMNP management. The park residents desire the same development opportunities as those available in villages outside the park. Residents claim that they have the right to use the land as their ancestors did, and that they also have similar rights as other villagers. The SMNP management hopes that the residents would eventually move out once they find good prospects outside. This potential conflict is complicated by the alignment of the park boundary, which cuts through most of the villages.

As noted, the overall planning and management of SMNP now rests with the Amhara Region, but EWCO is mainly responsible for the policy and monitoring of national parks. The national park policy strongly emphasises strict protection of the park, where human uses are not permitted, except for tourism, and scientific research.

The park headquarters is at Debark, $50 \mathrm{~km}$ outside the park boundary. Since the late 1970 s, due to political insecurity, the six outposts inside the park have no longer been used as permanent residences for wildlife guards. This affected surveillance and the monitoring of resource use inside SMNP. During this period of political instability, relations between farmers and park staff were reported to be tense because park staff were asked to help the military resettle villagers along the northern lowland escarpment. In 1994, a chief park warden, four senior staff, and about 20 wildlife guards were responsible for controlling and monitoring activities within SMNP. In recent years, part of the park administration was transferred to Sankaber, Gich and Chennek, where housing facilities for wildlife guards were constructed.

Because of the inherent political problems and the centralised system of government, there have been no efforts to include local communities in the planning and management of SMNP, which is characteristic of Ethiopia in general. Since conflicts are deeply rooted and complex, there are no easy answers, although theoretically a balanced approach seems to be sensible. However, implementation can be difficult.

At present, the national park policy-makers and management staff want a national park with as little human disturbance as possible. They argue that this is essential as only a tiny fraction of Ethiopia's habitats and wildlife remain unaffected by human pressures, and that, if encroached upon, SMNP will become much like other heavily eroded and degraded farmed landscapes of the Ethiopian Highlands. In reality, the goal of removing all intrusions from the park is not achievable in the short-term: so "illegal" crop cultivation and livestock production are tolerated at present levels, but intensification or further encroachment is resisted. Park management wishes to have more tourists in the national park and thus generate more income for the park administration. This would require an improved tourism infrastructure, which could benefit the villages inside the 
park: but this is seen as going against the policy of reducing pressure on natural resources.

Reaching a consensus can be very difficult when the goals and objectives of the stakeholders are so divergent. The example of international intervention in SMNP illustrates this. As part of the international effort to help SMNP deal with its problems with local land users, the Project Formulation Mission (PFM) for the Wereda Development Fund (WDF) was started in July 1994. Its main objective was to provide funds for financing rural infrastructure and planning in consultation with local levels of Government and communities. Support for decentralisation was seen as a way to achieve sustained poverty alleviation, which is the central aim of the WDF. Owing to the conflicts between stakeholders over road alignment (see above), consensus could not be realised. The first PFM for the Natural Resource Conservation and Agro-forestry Project took place in June/July 1995. During the discussions, it became clear that it was not possible to cover the whole buffer zone around SMNP, and that no interventions would be made inside the park (resident villages). It was decided that the Project activities would concentrate on 18 villages to the north of SMNP; and that the scope would be extended from a narrow resource conservation and agro-forestry project to a broader "sustainable development project", including resource conservation, sustainable agricultural development, access and infrastructure development.

The main concerns of the SMNP management include increasing use of park resources by local communities, the low population of the Walya ibex and the Simen wolf, the dislocation of the ibex withir their habitat, and the impacts of access and development programmes proposed by the government in peripheral areas. The SMNP management is interested in relocating resident villagers. Although an open commitment for resettlement is less likely at the moment, the strategy followed by the SMNP management is to prohibit any development activities which might favour local communities, i.e., no infrastructure, no resource conservation and no fuelwood plantations inside the park. The hope is to make the area as unattractive as possible for resident peoples, thus encouraging emigration.

Local resident peoples and communities outside the park want urgent solutions to problems of land, forest, wildlife and water. Similarly, villagers complain that the SMNP management excludes them not only in the planning and decision-making process, but from the right to share in its benefits, such as employment opportunities as game scouts and from tourism. Local communities claim that they were the sole guardians of the parklands before the State gained control of the area in the name of the national park. Hence, they feel they should be given preferential treatment in benefiting from the opportunities created by the park. For local communities the highest priority is to increase the area of cultivatable land per household, improve food security, and improve health care. They give a rather lower priority to adjusting park boundaries, developing agricultural extension services, improving education and improving access.

\section{Critical evaluation of lessons learnt}

Given the gap between the SMNP management's priority for increased protection for the park, and the local communities' aspirations for agricultural land, forest resources and other basic needs and services, it would seem that there is very little room for agreement. The needs felt by local communities are typical of impoverished rural environments, 
where survival is the paramount concern. From SMNP's standpoint, the parklands are the only viable habitat for the endangered wildlife and are important watershed areas for a far wider area.

Given the present conditions in the Simen region, it is easy to imagine what would have happened to the area had a national park not been declared. Moreover, there is a strong case to be made that the park does play a role in safeguarding life support systems by conserving nationally and globally scarce wildlife, protecting water sources and supporting the livelihood of several thousand villagers by nurturing agriculture through soil and water conservation. Yet, this is not enough, as the demand for land and forest resources among the immediate local community grows every year.

Despite this bleak situation, there is hope for a sustainable development path for SMNP. The park's need for protection can be achieved through a zoning system, which separates the intensively used areas from protected locations. Local level communityoriented development programmes should be implemented in sectors such as education and health. To resolve the current conflicts between various stakeholders, a consensus building process must be initiated. Even "agreeing to disagree" could be a starting point; then at least people could come together and voice their concerns, an experience that can lead to discussion and eventually to joint problem-solving.

\section{Major challenges for the future}

SMNP illustrates the complex dilemma of reconciling conservation with development in a region of great rural deprivation and poverty. In such a situation, protected area management with a strong remit for protection but without a concern for human development is no longer a valid approach. Problems of biodiversity and livelihood needs are intricately linked: without the achievement of one, the other cannot be fulfilled.

Many protected areas are now making efforts to reverse earlier trends, and share benefits with local communities. Through sustainable forms of tourism, for example, income and employment opportunities have been made available to local communities who are beginning to appreciate the significance of the protected area. Such a prospect is not impossible in Simen. But this requires local involvement in resource management and park planning, and empowerment in decision-making, which are fast becoming standard strategies to gain local support elsewhere. The ideals of a park can never be achieved if local communities are antagonistic towards it. This is what we can learn from the Simen region.

\section{References}

Hurni, H. (1986). Management Plan. Simen Mountain National Park and surrounding nural area. UNESCO World Heritage Committee/Wildlife Conservation Organization, Ethiopia. 
Hurni, H. and Ludi, E. (2000). Reconciling conservation with sustainable development. A participatory study inside and around the Simen Mountain National Park, Ethiopia. Centre for Development and Environment (CDE), University of Berne.

Nievergelt, B. (1996). Field study on the flora and fauna of the Simen mountains, January 1996: A summarized report. Unpublished, 5pp.

Shackleton, D.M. (Ed.) (1997). Wild Sheep and their Relatives. IUCN/SSC Caprinae Specialist Group, IUCN, Gland, Switzerland and Cambridge, UK.

Sillero-Zubiri, C. and Macdonald, D. (Eds.) (1997). The Ethiopian Wolf. Status Survey and Conservation Action Plan. IUCN, Gland, Switzerland. 



\section{Case study 7}

\section{Sagarmatha (Mt. Everest) National Park, Nepal}

China

India

Sagarmatha

(Mt. Everest)

Nepal

National

Park 



\section{Case study 7}

\section{Background information 8}

Sagarmatha National Park (SNP) lies in the Solu-Khumbu District of the north-eastern region of Nepal. The park encompasses the upper catchment of the Dudh Kosi River system, which is fan-shaped and forms a distinct geographical unit enclosed on all sides by high mountain ranges. The northern boundary is defined by the main divide of the Great Himalayan Range, which follows the international border with the Tibetan Autonomous Region of China. In the south, the boundary extends almost as far as Monjo on the Dudh Kosi. Its coordinates are $27^{\circ} 45^{\prime}-28^{\circ} 07^{\prime} \mathrm{N}, 86^{\circ} 28^{\prime}-87^{\circ} 07^{\prime} \mathrm{E}$.

The area is approximately $1,150 \mathrm{~km}^{2}$ and consists of a rugged landscape of high mountains, glaciers, hanging valleys and constricted fluvial terraces. Elevation in the park ranges between 2,800 and $8,848 \mathrm{~m}$. Some of the world's highest peaks, such as Mt. Everest $(8,848 \mathrm{~m})$, Lhotse $(8,501 \mathrm{~m})$ and Cho Oyu $(8,153 \mathrm{~m})$, are within the park boundaries.

$69 \%$ of the park is barren land above $5,000 \mathrm{~m}, 28 \%$ is grazing land and nearly $3 \%$ is forested. SNP can be broadly divided into three vegetation zones based on altitude: the lower altitudinal belt (below $3,800 \mathrm{~m}$ ) consisting of temperate forests and woodlands; the middle zone $(3,800-4,200 \mathrm{~m})$ of sub-alpine forests and shrubland; and the upper zone (above $4,200 \mathrm{~m}$ ) of tundra vegetation (Byers, 1987). Additionally, there is a small area of lower montane temperate forest between $2,800-3,200 \mathrm{~m}$.

In common with the rest of the Nepal Himalaya, the park has comparatively few (28) mammalian species, apparently due to the geologically recent origin of the Himalaya and other evolutionary factors. However, owing to its varied topography, climate and vegetation, the region supports rich animal populations (Jefferies, 1984). Larger mammals include lesser panda Ailurus fulgens (EN), snow leopard Uncia uncia (EN), Himalayan musk deer Moschus chrysogaster, mainland serow Capricornis sumatraensis (VU) and Himalayan tahr Hemitragus jemlahicus (VU) (Garratt, 1981; Jefferies and Clarbrough, 1986). Sambar Cervus unicolor has also been recorded. The tahr population is estimated to total at least 300 individuals. Both goral and serow appear to be uncommon (Lovari, 1990). Results from recent surveys suggest that populations of tahr and musk deer have increased substantially since the park was gazetted and probable signs of a recovery in the snow leopard population were seen in the Gokyo Valley by Jackson and Ahlborn (1987).

Inskipp (1989) lists 152 species of birds, of which 36 are breeding species for which Nepal may hold internationally significant populations. The park is important for a number of species breeding at high altitudes, such as blood pheasant Ithaginis cruentus, robin accentor Prunella rubeculoides, white-throated redstart Phocnicurus schisticeps.

8 Information compiled by S.J.Nepal for WWF-I. 
grandala Grandala coelicolor and several rosefinches. The park's small lakes, especially those at Gokyo, are used as staging points for migrants and at least 19 water bird species have been recorded (Inskipp, 1989; Scott, 1989).

The site was designated as a National Park, IUCN Management Category II, on 19 July 1976 and inscribed on the World Heritage List in 1979. The responsibility for planning and managing SNP falls with the Department of National Parks and Wildlife Conservation (DNPWC), which is under the jurisdiction of the Ministry of Forests and Soil Conservation. The National Parks and Wildlife Conservation Act of 1973 excludes any forms of human use, except tourism, scientific research and education. In 1993, the Government passed the Wildlife Conservation Act, with a provision to return up to $60 \%$ of the park revenues for local community development.

\section{Indigenous/Traditional people(s)}

Present day inhabitants of SNP are mostly the indigenous Sherpa community, believed to have migrated from an eastern province in Tibet some four centuries ago (Jefferies, 1982). Sherpa practice a form of Tibetan Buddhism; however, they consider themselves quite distinct from the Tibetans. Originally nomads, Sherpas began to settle permanently after the introduction of the potato in 1850 , while maintaining transhumance migration (Hardie, 1974 cited in Bjoness, 1980). The park is also home to a small population of other ethnic groups who have migrated there from the middle hills and lowland areas of eastern Nepal. There are eight major settlements and more than 60 subsidiary settlements (Stevens, 1993), some of which have been transformed to permanent or semi-permanent tourist villages. All the settlements are technically excluded from the park.

The latest statistics show that the total population within the park is 3,064 , which had increased from 2,688 in 1991 (Nepal, 1999). After the first successful ascent of Mt. Everest by Tenzing Norgay and Edmund Hillary on 29 May, 1953, mountaineering and trekking flourished in the region bringing profound changes in Sherpa's economy, which had traditionally relied on agriculture, animal husbandry and trade. Today, tourism is the mainstay of most Sherpas. Everest is now visited by more than 17,000 tourists every year, mostly trekkers and mountaineers. During peak tourist months, visitors (guides and porters included) exceed the local population by a factor of five.

The number of lodges has increased from seven in 1973 to 17 in 1980, 74 in 1990 and 224 by the end of 1997 ( Nepal, 1999). These have a total accommodation capacity of 4,000 beds. It is estimated that tourism may have provided income and employment opportunities for 60-80 percent of the local population. As a result of tourism, local Sherpas have become very affluent compared to the average Nepali citizens. Park-based tourism has significant regional economic effects, not only in terms of merchandised goods sold in the area but also affects the origin of the porters and labourers hired in the lodges: a survey at Jorsalle entrance post indicated that porters came from as many as 17 different districts. Thus, tourism has played a major role in improving the livelihood conditions of the majority of the Sherpas.

In Nepal, where there are many indigenous peoples and ethnic minorities, intensified use of forests and grazing lands by these communities poses a major conservation dilemma. In the past, traditional resource management practices were totally ignored, which resulted in conflicts and resource degradation. Since the early 1990 s, owing to 
political reforms and changes in government policies concerning land and forest resources, indigenous communities are seen more as partners in resource management and conservation. Indeed Nepal now provides many examples of community-based forestry practices and tourism development. The Annapurna Conservation Area Project (ACAP) is one such endeavour where a partnership approach is adopted, based on traditional systems (Nepal, 1999). Although, local villagers may not always enjoy true empowerment, at least the path chosen is based on democratic values.

\section{Involvement of the indigenous peoples in the management and administration of SNP}

Historically, Sherpas have developed a strong sense of community stewardship, as the whole community took responsibility for protecting common properties such as forests and grasslands. The relative stability of forests in the park has been attributed to the indigenous systems of forest protection and management practiced under the "shingii nawa" institution. The shingii nawa is composed of a powerful group of local people who annually select villagers to act as forest guardians. Stevens (1993) has reported different types of protected forests and secular preserves and local variations of the shingii nawa. Forest guards ensured that villagers observed the rules and regulations, and were also given the authority to penalise when regulations were violated. Such a system of controlled use based on local interests ensured that forest products were harvested in a sustainable manner.

With the passage of the Forest Nationalisation Act of 1957, all forest cover within the country became government property. Any local rights to forest management were denied, undermining the local management regulations and institutions. While this accelerated forest destruction in many parts of the country, particularly in the lowlands, Stevens (1993) has reported that, in the Everest region, it was a more gradual process, contrasting with the widespread deforestation reported by several authors elsewhere in the country. However, with the rapid development of tourism in the late 1960 s and early 1970 s, there was increased use of firewood, resulting in highly visible tree felling in many areas in the park. As noted earlier, this development coincided with the government's planning of a national park in the area. Subsequent evaluations were made in 1972 by government officials and in 1974 by a team from New Zealand; SNP was formally gazetted in 1976.

The nationalisation of forests and the rapid growth of tourism have had negative impacts on community stewardship and responsibility. Previously friendly neighbours have suddenly become envious and hostile competitors. Stiff competition, physical and mental stress, and the challenge of running a lodge have taken a heavy toll on Sherpa community life, resulting in a somewhat fragmented society. Erstwhile active members of the community now find very little time for communal activities. The present day Sherpa life generally revolves around the tourists, whereas in the past community and religion were the most important aspects of Sherpa culture.

Since the establishment of the park, important achievements have been made in wildlife conservation, promotion of alternative energy sourees and energy-sasing devices, and in local involvement in park management. While the declaration of SNP may have saved this region from further environmental disruptions, the rapid development of tourism has created many problems for the park management. 
The park has no jurisdiction and control over tourism-related activities. The result has been the haphazard development of tourism giving rise to problems such as garbage pollution, trail damage, pollution of drinking water sources and socio-cultural anomalies. Despite the availability of electricity in some tourist villages such as Namche, and the adoption of various alternative energy sources and energy-saving devices by the lodges, the demand for firewood and timber continues. Even today, firewood constitutes a major source of energy for most lodges, while timber is the main construction material. Energy demands in the Everest region have gone up significantly, as both the numbers of visitors and the lodges have increased dramatically. During the peak tourist seasons, Khumbu lodges consume over nine metric tons of firewood per day. Since cutting trees inside the park is prohibited, forested areas outside are increasingly under pressure to meet the growing demands. Also local people, facing government-imposed restrictions on firewood collection and timber harvesting inside the park boundary have little appreciation for government-sponsored conservation activities.

SNP's early management was in the hands of park specialists supported by the New Zealand government. The New Zealanders had an ambitious goal of making the park a world class natural heritage. Their efforts were mainly focused on forest protection and regeneration; however, they also realised the potential and the importance of linking park management with local Sherpas. During its formative years, the park was strongly opposed by the local people. As part of the government's protection policy, military personnel were deployed in the park, causing further concern among local Sherpas. Indeed, Hillary (1982) reported that, in the 1976 village council elections in Khumbu, all the chief candidates were opposed to the national park. Khunjo Chumbi, one of the candidates and Hillary's old friend, said that "Hillary first brought sugar to the lips of the Sherpas, but he is now throwing salt in their eyes" (Hillary, 1982, p. 702).

Realising that without local support the park's future would not be secured, the decision was taken to draw the boundaries so as to exclude all settlements from the proposed park. It was also decided to involve local people in park management. These steps helped to reduce suspicion and ill feeling. Park management focused on responding to local people's needs for firewood, timber and grazing pasture, and also on environmental concerns as dictated by the funding agencies.

Owing to the growing conflict between the local people and park administration, His Majesty's Government in 1993 passed the Wildlife Conservation Act, with a provision to return up to 60 percent of the park revenues to local community-based development. Similarly, the Buffer Zone Management Act enabled buffer zones to be set up around protected areas, where local communities are supported through community-based development programmes. In line with these regulations, the forest areas to the south of the park were informally considered as a buffer zone, though the objectives are vague and poorly understood by park officials and local people.

The New Zealanders prepared the ground work for park management, including environmental protection, community development and tourism management (Garatt, 1981). In 1981, they were succeeded by Nepali administrators from DNPWC. The Department started recruiting Sherpas for various administrative and technical jobs: at one time, both the chief warden and assistant warden were local Sherpas.

Several local institutions have emerged to tackle the problems related to environment and tourism. One such institution is the Sagarmatha Pollution Control Committee (SPCC), which was established in 1991 with initial support from WWF-USA. Run by 
local Sherpas, this local NGO started receiving substantial funding from the Ministry of Tourism, which provides the institution with almost $4 \%$ of the climbing fees collected from the Everest region (SPCC, 1997). SPCC started an ambitious project to clean up garbage and educate local people and visitors about the environmental sensitivity of SNP. Its philosophy is that of community responsibility and action to tackle local problems, for it is the local community which is most affected (both positively and negatively) by tourism.

The impact of the garbage clean-up campaign is clearly evident as tourist trails in the park are much cleaner than in the past, when the route to Everest was infamously labelled "the garbage trail". Although SPCC has now started building alliances with other local and foreign agencies, its future depends very much on the support that it receives from the government, outside agencies and local Sherpas.

Other indigenous institutions active in improving the environmental conditions include the monasteries in the park. One of the most important of these is the Tengboche Monastery, located on the main trail to the Everest Base Camp. This monastery works for local level community development, with plans to address issues such as drinking water supply, electricity and porters' shelters.

Indigenous efforts to improve environmental conditions, tourism management and better livelihood are supported by various governmental and international agencies, including the Himalayan Trust, Öko-Himal, WWF-USA and local Village Development Committees represented by locally-elected Sherpas. The government's involvement at the local level is largely restricted to park management, funding support to SPCC, collection of trekking permit fees and maintenance of the military regiment at Namche.

\section{Critical evaluation of lessons learnt}

Four events, three external and one internal, forever altered the socio-economic and environmental conditions in the Everest region. These were the Chinese occupation of Tibet, resulting in an exodus of Tibetans to Khumbu in the late 1950s and early 1960s; the boom in international tourism in the $1960 \mathrm{~s}$; the nationalisation of forests and grazing lands in 1957; and the establishment of the national park in 1976.

SNP has limited its own activities to protection and surveillance, with almost no community-oriented activities. The main goal of the park is conservation; little attention has been given to tourism management and local community development. However, DNPWC has made some efforts towards overcoming the conflicts with the Sherpa community. For example, the traditional shingii nawa forest management system was reinstated in 1983, under which, two village-elected forest guards would be responsible in each settlement for protecting the local forests. However, the new system does not appear to have been wholly effective and lacked universal support, since the guards were seen more as park employees than village folk (Stevens, 1993).

In recent years, the historical trade that was disrupted by the cvents in Tibet has recovered. Traditional forest management systems, which collapsed after the forest nationalisation, have been reinstated, and attempts have been made to balance the impact of the park through the introduction of the buffer zone concept and community approaches toward forest conservation. 
Nonetheless, the recent political changes in the country have encouraged local people to speak out about their grievances against the park-imposed regulations. As a result, many decisions regarding forest management have now been entrusted to local people, and monasteries have been given authority to manage forests within their jurisdiction. While the local community appreciates these developments, conflict over forest management seems certain to continue as the goals of the park and the local communities are very different. It remains to be seen if handing over forests to the local community has been beneficial in all respects.

In the past, DNPWC has adopted a top-down approach, though recent regulations emphasise the need for a people-centred strategy. The Department listens to suggestions made by the park wardens, but major policy decisions are taken at the centre. Since the establishment of national parks in Nepal, the government has mobilised military personnel to protect wildlife within SNP. While this has protected the park from potential illegal poachers and hunters, and has thus benefited wildlife, it has also caused resentment among the local population. They see the military as a threat, especially as it takes away many of the funds from the regular parks budget.

\section{Major challenges for the future}

The intensity of tourism development is a key feature of the region. It is important that tourism does not undermine the Everest region, and that the planning and management of the region should be based on clearly-defined objectives towards tourist activity. Without the designation of a national park, it is reasonable to assume that the Khumbu landscape would have been much more degraded from the pressures of tourism. The establishment of the park is therefore to be welcomed, even if it has resulted in some tension between the authority and the local community. SNP should continue to be at the centre of efforts to promote and manage tourism in Nepal on ecologically and socially sustainable lines, and to achieve sustainable rural development in the Himalayas region.

\section{References}

Bjonness, I. (1980). Ecological conflicts and economic dependency on tourist trekking in Sagarmatha (Mt. Everest) National Park, Nepal. An alternative approach to park planning. Norsk Geografisk Tiddskrift 34: 119-138.

Byers, A. (1987). An assessment of landscape change in the Khumbu region of Nepal. Mountain Research and Development 7: 77-80.

Garratt, K.A.J. (1981). Sagarmatha National Park Management Plan. Department of National Parks and Wildlife Conservation, Kathmandu.

Hardie N. et al. (1987). Nepal-New Zealand Project of forest management in KhumbuPharak. Unpublished report.

Hillary, E. (1982). Preserving a mountain heritage. National Geographic 161: 696-702. Inskipp, T. (1989). Nepal's forest birds: their status and conservation. International Council for Bird Preservation Monograph 4. 160pp. 
Jackson, R. and Ahlbom, G. (1987). Snow leopard surveys in Nepal. Sagarmatha (Everest) National Park. Cat News 7: 24-5.

Jefferies, B.E. (1982). Sagarmatha National Park: the impact of tourism in the Himalayas. Ambio 11: 274-81.

Jefferies, B.E. (1984). The Sherpas of Sagarmatha. In: McNeely, J.A. and Miller, K. (Eds.), National Parks, Conservation and Development. Smithsonian Institution Press, Washington DC, USA. Pp. 473-78.

Jefferies, M. and Clarbrough, M. (1986) Sagarmatha: Mother of the Universe. The Story of Mount Everest National Park. Cobb/Horward Publications, Auckland, New Zealand. 192pp.

Lovari, S. (1986). Some notes on the wild ungulates of the Sagarmatha National Park, Khumbu Himal (Nepal), Caprinae News 5: 2-4.

Mehta, J.N. and Kellert, S.R. (1998). Local attitudes towards community-based conservation policy and programmes in Nepal: a case study in the Makalu-Barun Conservation Area. Environmental Conservation 25: 320-33.

Nepal, S.K. (1999). Tourism-induced environmental changes in the Nepalese Himalaya. A Comparative Analysis of the Everest, Annapurna, and Mustang Regions. PhD Dissertation submitted to the Faculty of Natural Sciences, Institute of Geography, University of Bern, Switzerland.

Sagarmatha Pollution Control Committee (SPCC) (1997). Annual report for the fiscal year 1996-1997. Publisher and place published not specified.

Stevens S.F. (1993). Claiming the high ground. Sherpas, subsistence, and environmental change in the highest Himalava. University of California Press, USA. 



\section{Case study 8}

\section{Doi Inthanon National Park, Thailand}

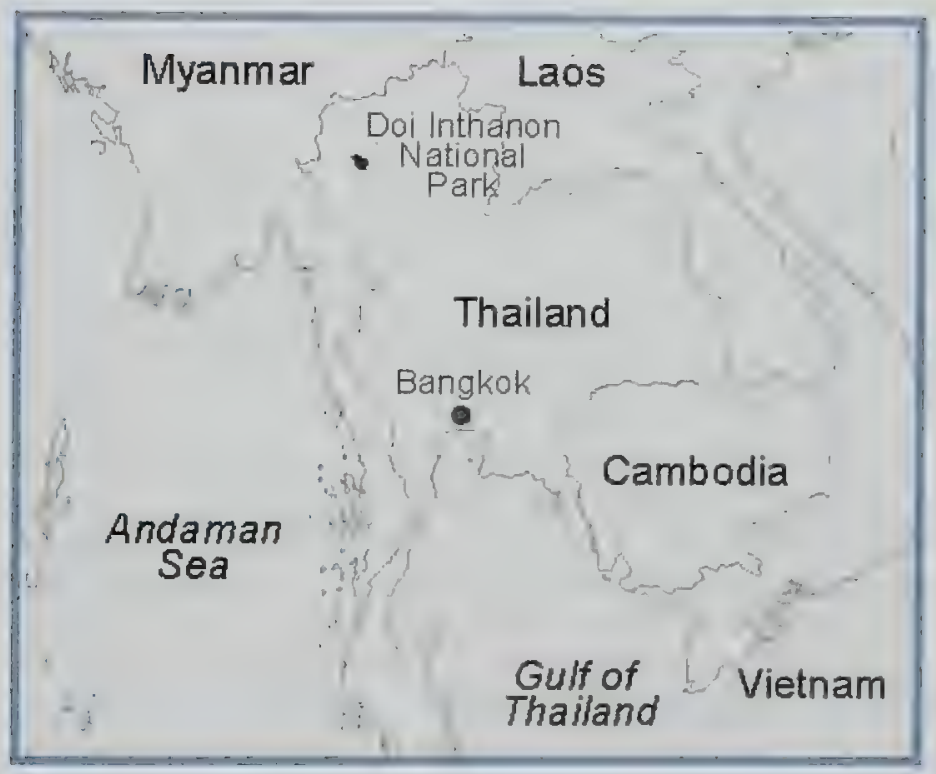





\section{Case study 8}

\section{Background information ${ }^{9}$}

Located about $60 \mathrm{~km}$ west of Chiang Mai in northern Thailand, the Doi Inthanon National Park (DINP) is one of the most popular parks for birding and nature study in Thailand. Designated as a Reserved Forest in 1959 and as a National Park in 1972, DINP has a total land area of $482 \mathrm{~km}^{2}$. It is well known for montane forest birds, supporting Thailand's only population of ashy-throated warbler Phylloscopus maculipennis together with an endemic race of the green-tailed sunbird Aethopyga nipalensis (Round, 1988). Over 382 bird species have been recorded from the park. Coordinates at DINP's central point are $18^{\circ} 31^{\prime} \mathrm{N}, 91^{\circ} 33^{\prime} \mathrm{E}$.

Doi Inthanon is a large granite batholith and the highest mountain $(2,565 \mathrm{~m})$ in Thailand. DINP has a monsoon climate with a variety of natural habitats, most notably hill evergreen forests. Epiphytes, lichens and lianas are abundant at higher altitudes where precipitation exceeds $2,000 \mathrm{~mm}$ per annum. The terrain above $1,800 \mathrm{~m}$ is covered by virgin groves of orchids and rhododendrons. DINP is the only location in Thailand where Rhododendron delavayi is found.

DINP has a unique fauna, including Assamese macaque Macaca assamensis (VU), white-handed gibbon Hylobates pileatus (VU), tiger Panthera tigris (EN), and representatives of Himalayan mammal species, such as Pere David's vole Eothenomys melanogaster and mole-shrew Anourosex squamipes (Sayer, 1981). A recent study of springtails reported 112 species at the summit of the mountain, of which 90 were new to science (Dearden et al., 1996).

The park is very popular among domestic tourists because of its temperate climate and attractive waterfalls. It also receives some foreign tourists. Visitor numbers increased three-fold between 1983 and 1993 - from over 312,000 to 936,000 (DINP, 1993). The park is being promoted as one of the prime ecotourism destinations in northern Thailand for its many natural and cultural attractions, including the summit itself, birds and other wildlife, waterfalls, walking trails, scenic overlooks, religious shrines, caves and ethnic highlander hill tribes. Since DINP is in a remote, rural area, sustainable forms of tourism development could lead to increased income and employment opportunities for local communities.

Management of the park is entrusted to the National Parks Division (NPD) of the Royal Forestry Department, which falls under the jurisdiction of the Ministry of Agriculture and Cooperatives. The National Park Act of 1961 states that the main objectives of a national park is to protect the area in a primitive state where human impacts are not permitted, except for education and scientific purposes (Pipithvanichtham. 1997).

9 Case study prepared by S.J.Nepal for WWF-I 


\section{Indigenous/Traditional people(s)}

Roughly 4,500 people live inside DINP boundaries. Main inhabitants include the Karen, ethnic Thais and Hmong. Karen and Hmong are considered hill tribes. Additionally, 8,000 people live in 14 villages within five kilometres of the park (Hvenegaard and Dearden, 1998). A high proportion of households use the park for collecting plants (77\%), fuelwood $(88 \%)$, construction materials $(66 \%)$ and hunting $(47 \%)$ (Dearden et al., 1996). The central government perceives the hill tribes as a source of problems, because they contribute to deforestation and soil erosion, grow opium poppies, are thought of as an unstable political factor and often do not consider themselves to be Thai nationals (Cooper, 1979).

Doi Inthanon was established without regard to the presence of hill tribe populations within the park area. The population in the area of the then newly-established DINP was reported in 1974 to be low $(1,700)$, but had increased to 2,500 by 1982 (Dobias, 1982 cited in Dearden et al., 1996). Between 1971 and 1983, the average annual growth of Karen population was around $2.5 \%$, as a result of natural increase. Due to immigration, the number of Hmong grew more rapidly (Mischung, 1986 cited in Dearden et al., 1996).

The indigenous communities in DINP are very poor and face food shortages. Compared with the Karen, the Hmong have however benefitted from their early engagement in opium cultivation and from government-sponsored development projects to replace this with other income-generating activities (Dearden et al., 1996). The Karen are not involved in such projects.

Indigenous communities, particularly the northern hill tribes, are thought by many in Thailand to have little concern for society at large. The hill tribes are seen as the main culprits for resource degradation in northern Thailand. Age-old highland traditions, such as slash-and-burn agriculture and forestry practices, are considered harmful to the ecology and environment, especially when the numbers involved increase. Hill tribes are often the victims of violence from other groups, and find themselves increasingly alienated from Thai society as a whole. Protected area authorities follow policies to curtail indigenous resource utilisation practices, and indigenous involvement in park management is discouraged.

\section{Involvement of the indigenous peoples in the management and administration of DINP}

Since 1975, more than $40 \%$ of DINP area, and 34\% of the surrounding forest, are reported have been encroached upon (Dearden et al., 1996). Illegal hunting and habitat encroachment have resulted in the elimination of mammals, such as tiger, Asian elephant Elephas maximus (EN), banteng Bubalus javanicus and gaur B. gaurus, and birds including most hornbills and white-winged duck Cairina scutulata (EN).

Many other highland protected areas in Thailand are located in areas which the Karen people have long occupied. Compared to other ethnic groups, the Karen's methods of agriculture and forestry are conservation-oriented. Nevertheless, these traditional practices do have appreciable ecological impacts. Even though much forest remains in northern Thailand, there has been an enormous loss of wildlife.

When DINP was established, this traditional form of slash-and-burn agriculture was seen as damaging to the ecology of the park. In many areas, shifting cultivation was 
brought to an end rather rapidly, with no income-generating projects to compensate local people for the loss of land: this was true particularly for the Karen. The Hmong were however compensated by a Royal Project, initiated by the King in 1979, to improve the livelihoods of local people and preserve forests: this encouraged the growing of mainly temperate cash crops to replace opium. So government policy in northern Thailand has been to support the opium growers (mainly Hmong) rather than the conservationminded Karen, even though the Karen's resource management practices have been appreciated by many NGOs and academic institutions.

Thailand's laws governing national parks, which were enacted in the early 1960s, assumed that human use and nature preservation were incompatible, and are therefore particularly strict on habitat protection. However, their enforcement has often been against local villagers seeking to use the resources to which they previously had access rather than against the rich and influential.

While the Royal Forestry Department (RFD) considers park inhabitants to be "illegal occupants" or "squatters in the forests", this claim is disputed Karen and Hmong believe that they had been living in DINP for over 100 years, and challenge the RFD's assertion that the local communities have in fact migrated more recently into the park. RFD officials now admit that when an inventory of national forest reserves was originally undertaken to determine their suitability for protected areas, inhabited areas were mistakenly included within the proposed protected area boundaries (Pipithvanichtham, 1997).

Many hill tribe people were evicted by force from the park and the relationship between the indigenous peoples and the park authorities remains difficult. For example, the indigenous communities are given hill tribe identification cards, which makes it impossible for them to secure formal rights to use or own land (Sturgeon, 1999).

DINP management policies largely preclude local involvement or empowerment, and there is little consultation with the indigenous communities. A DINP master plan has been formulated that proposes the clear demarcation of boundaries, removal of villages from certain watersheds, restoration of old agricultural clearings, establishment of a "special use zone" for other agricultural holdings that can be closely supervised by park officials, control of future expansion of human settlements, restriction on the use of pesticides, more attention to tourism potential of the hill tribes, and education aimed at understanding the nature and function of a national park. However, the implementation of these proposals has been slow, mainly because of disagreements over the role of the indigenous populations.

One area where progress may be possible is tourism. There is a potential for community-based tourism among hill tribes, who are seen by tour operators as important cultural assets. Plans are underway to create a community-based ecotourism destination in Karen village, so as to replace the existing dependence on flower plantations, which involve heavy chemical use. A management board is planned to oversee tourism-linked conservation projects: this will include village representatives, RFD officials, representatives from NGOs and academic institutions. Another ecotourism project in DINP plans to augment villagers" incomes through a community-based tree nursery and the active involvement of villagers in forest replanting. The villagers were keen to explore the possibilities of re-introducing gibbons into the area, from which they had apparently been hunted out some ten years ago. 


\section{Critical evaluation of lessons learnt}

It is difficult to achieve the aims of protected areas if a hostile population surrounds them. In DINP, indigenous communities do not consider that they are seeking favours from the park authority, but the right to adhere to customary practices and to maintain a sustainable livelihood. To address the alienation of local people, several strategies are needed:

5. the park management needs to engage in a serious discussion over the property claims of indigenous communities within DINP, especially as much of the land now classified as protected includes land and resources which local people believe belonged to them before the park's designation;

* the management of the park should aim to create local benefits through conservation-related activities, such as ecotourism, and to link traditional resource management practices with modern conservation approaches. This would stand a better chance of success than resorting to coercive measures, such as relocation, which bring insecurity to the people concerned and often lead to violent protests;

a communications should be improved between the indigenous communities and the park officials, and consultative mechanisms for this should be put in place;

government agencies need to co-ordinate their contacts with indigenous peoples. The hill tribes in and around DINP complain that they are given contradictory directives by government officials, depending on which agencies are approached. Each agency has its own goals, for example RFD and DINP are concerned about the protection of park resources, the Department of Agriculture focuses on agricultural development and maximising crop productivity, while the Department of Interior oversees programmes for the welfare of the hill tribes. None of the agencies appreciates the whole range of issues and the severity of conflicts. There is therefore a need for a common management plan, or agreement, based on clearly-articulated priorities to guide all the agencies' programmes;

t local communities should be included in planning activities in and around DINP. Monitoring the activities of 4,500 people resident in the park with a protection staff of 25 rangers is almost impossible (Dearden et al., 1996). Moreover, many illegal activities affecting DINP arise from the additional 12,000 people who live in local communities around the park. DNIP therefore urgently needs to develop management strategies which provide the indigenous communities with incentives to support the park's protection;

empowering indigenous communities should be based on co-management between local communities and the government, although within the context of Thailand's hill tribes such an approach will be challenging for a highly centralised government system. Given the lack of trust between the government and the hill tribes, it is unlikely that the government will soon be willing to accept park planning and management based on local empowerment and co-management. However consultative dialogues should be initiated to "break the ice": a starting point would be discussions and negotiations leading to the formulation of a multi-stakeholder management plan. 


\section{Major challenges for the future}

Resource conflicts in DINP are deeply rooted, and can be addressed successfully only through a holistic approach to park management. Such an approach would need to improve local livelihood conditions, thereby reducing the reliance of indigenous people on park resources and so minimising conflicts and the need to enforce park rules and regulations. DINP should become part of an integrated land use system for the region and no longer be managed as an isolated physical entity. Issues that need to be addressed include education for hill tribe people, economic incentives such as community-based ecotourism, training of park staff on local livelihoods and indigenous knowledge systems, and the identification, formulation and implementation of suitable management strategies (Dearden et al., 1996). It is also important that resource use patterns, and the impacts of the various ethnic groups, are carefully investigated and analysed before policy decisions are taken to create incentives and disincentives for conservation.

\section{References}

Cooper, R.G. (1979). The tribal minorities of northern Thailand: problems and prospects. Southeast Asian Affairs: 323-32.

Dearden, P., Chettomart, S., Emphandu, D. and Tanakanjana, N. (1996). National parks and hill tribes in northern Thailand: a case study of Doi Inthanon. Society and Natural Resources 9: 125-41.

Dobias, R.J. (1982). The Shell guide to the national parks of Thailand. Bangkok.

DINP (1993). Annual Report of Doi Inthanon National Park (DINP) 1993. National Parks Division, Royal Forestry Department, Bangkok.

Hvenegaard, G and Dearden, P. (1998). Ecotourism versus tourism in a Thai National Park. Annals of Tourism Research 25: 700-720.

Mischung, R. (1986). Environmental adaptation among upland peoples of northern Thailand: A Karen/Hmong case study. Report to the National Research Council of Thailand, Bangkok.

Pipithvanichtham, P. (1997). Issues and challenges of ecotourism in the national parks of Thailand. In: Bornemeier, J., Victor, M. and Durst, P.B. (Eds.) Ecotourism for forest conservation and community development. Proceedings of an international seminar held in Chiang Mai, 28-31 January 1997. Pp.72-81.

Round, P.D. (1988). Resident forest birds in Thailand: their status and conscriation. International Council for Bird Preservation, London, UK.

Sayer, J.A. (1981). A review of the nature consen ation and policies of the Rolal Forest Department, Thailand. UN Food and Agriculture Organisation, Rome, Italy.

Sturgeon, J. (1999). State policies, ethnic identity, and forests in China and Thailand. Email version of an article posted to the Mountain Forum (originally published in the Common Property Resource Digest, January 1998). 



\section{Case study 9}

\section{Xishuangbanna Nature Reserve, China}

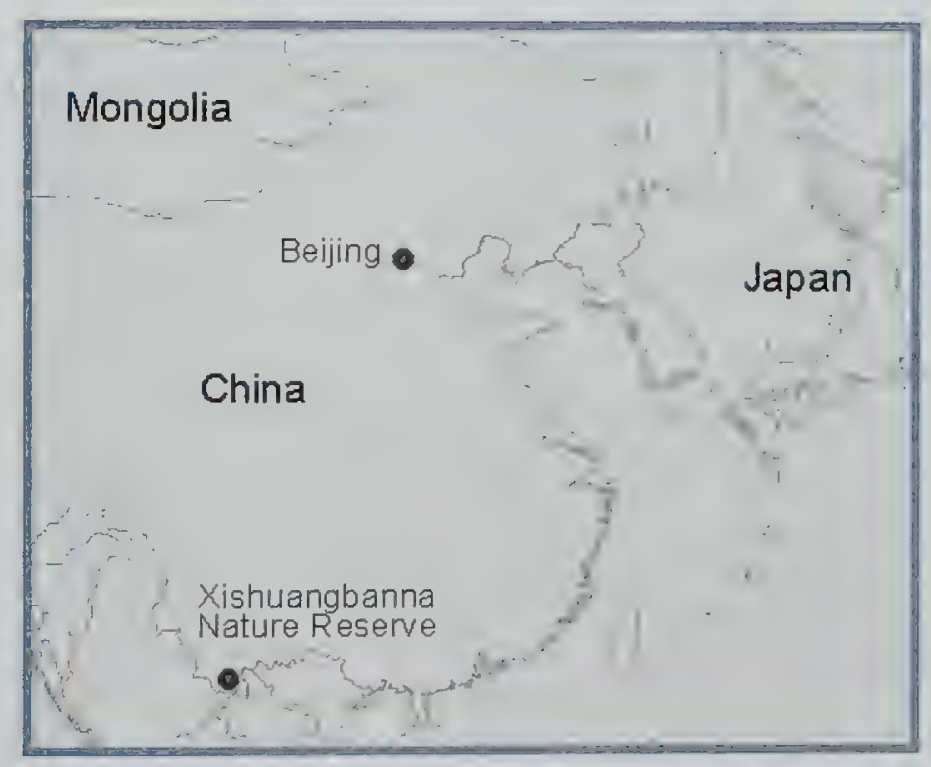





\section{Case study 9}

\section{Background information ${ }^{10}$}

Established in 1958, the Xishuangbanna Nature Reserve (XNR) is located in the southern region of the Yunnan Province. Sharing its border with Laos and Myanmar at the extreme southwest corner of mainland China, XNR has a total area of $2,070 \mathrm{~km}^{2}$. It is covered in biodiverse-rich tropical and sub-tropical forest. The reserve consists of five separate sub-reserves: the Mengyang, Menglun, Mengla, Shangyong and Mengao reserves. The elevation of XNR ranges between 420 and $2,300 \mathrm{~m}$ above sea level. $90 \%$ of the landscape is mountainous with rock formations of limestone, granite and sandstone. Situated at the climatic margins of tropical rainforest, XNR depends on the large number of foggy days in the year to augment precipitation. The coordinates at the central point of $\mathrm{XNR}$ are $21^{\circ} 47^{\circ} \mathrm{N}, 100^{\circ} 59^{\circ} \mathrm{E}$.

XNR supports rich flora and fauna. It has 3,500 species of higher plants, of which 300 are rare. There are 200 species of food plants, 100 species of oil plants, 20 species of aromatic oil plants, 100 species of rapid-growing trees, 50 bamboo species, and 300 species of medicinal plants. The reserve protects a number of threatened mammal and bird species, and some economically important plant species. There are 102 mammal species, including tiger Panthera tigris (EN) and Asian elephant Elephas maximus (EN). Around 427 bird species have been recorded from the area, with several species of conservation concern (IUCN, 1993).

The management responsibility of the reserve is vested in the Yunnan Provincial Forestry Bureau, which falls under the jurisdiction of the Ministry of Forestry ( $\mathrm{U} U \mathrm{CN}$. 1993). For management purposes, XNR is divided into core and experimental zones. Strict protection is observed in the core zone. Previously 18 villages were located in this zone, of which 10 were later relocated elsewhere. There are 86 villages in the experimental zone, where limited agriculture and subsistence hunting is permitted. Overall, the reserve has been assigned to IUCN Management Category IV. There are two types of land within the XNR prefecture: state owned land (reserve land) and communal land (agriculture and forestry). The reserve is part of the UNESCO Man and Biosphere Programme since 1993.

\section{Indigenous/Traditional people(s)}

XNR is home to several minority ethnic groups including Dai, Hani. Lahu. Bulang, Jino. Bai, Yao, Miao, Hui, Zhuang, Wa and Yi communities. Dai constitute the largest group (35 percent). These groups have strong cultural identities and maintain traditional beliefs and customs. The total population within XNR is over 14,000, which has doubled

${ }^{10}$ Case study prepared by S.J.Nepal for WWF-I 
within the past 20 years. Land use in XNR's prefecture mainly consists of forest: natural forest, community forest and fuelwood tree plantation, sacred forest grounds; and agricultural areas: permanently cultivated areas, shifting cultivation areas and tea plantations.

For over 800 years the indigenous communities, particularly the Dai ethnic group, have lived on, and farmed some of, the land which is now in XNR. These indigenous people traditionally relied on a wide variety of products, including timber, fuelwood, grass for thatch, meat, vegetables and medicines for domestic use and for sale. Harvesting timber in XNR is not a major traditional activity for these ethnic minorities nor is it profitable given market regulations (Albers and Grinspoon, 1997). Although villagers reported that some products, such as butterflies and mushrooms, are abundant despite high extraction levels, there are also shortages of some useful products, such as the leaves used for storing and serving food. Hunting is still practiced by the villagers (Santiapillai et al., 1990 cited in Nepal and Weber, 1995) and there is no shortage of home-made guns. Wildlife is hunted for food, but also to meet the demands of traditional Chinese medicine. Shifting cultivation and permanent agriculture extend over 13,000ha while much of the forest below $900 \mathrm{~m}$ has been converted to rubber plantations.

Policies during the Mao era dictated that all Chinese, regardless of their ethnic culture, religion or value systems should adopt the same nationally-determined, State-imposed culture. Indigenous communities and ethnic minorities were in many cases forced to abandon their traditions and adopt State-enforced policies: those that did not faced racial violence and prejudice. Since the political and economic reformation processes of the 1980 s and 1990 s, indigenous communities are slowly gaining their rightful place in the Chinese society. The tourism industry even capitalises on indigenous culture and customary practices. In the context of resource management, indigenous communities are allowed to continue with their practices, as long as they do not jeopardise the resources. There is some degree of flexibility on resource extraction from protected areas when this involves indigenous communities.

\section{Involvement of the indigenous peoples in the management and administration of XNR}

The management objectives of XNR are far from clear. For instance, the first objective states that any form of human use of resources inside its boundaries is strictly prohibited, but the second objective directly contrasts with this, allowing some forms of human use (Nepal and Weber, 1995). The balance between adequate protection and limited human use is difficult to enforce. With the growth in human population, increasing incidence of hunting and forest encroachment have been reported. Between 1949 and 1980, forest cover in XNR declined from $69 \%$ to $30 \%$. Local demands for firewood far outstrip supply (Shi, 1980).

In the past, the XNR officials were involved in routine protection tasks only. The concept of integrating rural development with park management is new not only in XNR but in other protected areas in China. The centralised system of government virtually ruled out local participation in park management. This has changed significantly in recent years.

In terms of legal status, although it has a quite restrictive classification, equivalent to a Habitat/Species Management Area, XNR managers are not bound by the same regu- 
lations on resource access. This is because Chinese national regulations, while banning the extraction of some products from protected areas in general, permit it in special circumstances. XNR managers note the practical impossibility and political difficulty of enforcing restrictions in an area populated by many ethnic minorities. They therefore follow more flexible rules than is the case in other protected areas in China. Moreover, following the regulations, which encourage managers to consider the "needs of local economic construction, the production activities and the everyday lives of local residents" (Grinspoon, 1996), park managers have taken the view that conserving resources within the reserve depends in part on good economic prospects for the neighbouring villages. They attach great importance to maintaining good relations with indigenous people so as to encourage stewardship of the reserve.

XNR's management plan thus rests on negotiations to balance the needs of local people with the goals of conservation. It is based on a trade-off: a lower level conservation in some parts, in return for the cooperation by villagers in conserving the remaining areas (Albers and Grinspoon, 1997).

Given the relatively small budget available for enforcement of access restrictions, XNR managers have implemented a plan that relies on improving the economic conditions of local people and on continual cooperation between managers and indigenous communities. This interactive management approach has three basic components:

a recognition of the rural people's economic dependence on, and historical relationship with, resources in XNR;

- activities to promote economic development outside XNR; and

- a system of negotiation and permission to allow some activities within XNR.

While the activities promoted outside XNR are important and have received attention, the recognition of historical rights and the negotiation system appear fundamental in establishing a long-term positive relationship between XNR managers and indigenous communities. The enforcement of some regulations, such as those relating to the extraction of vegetables, is impractical and will face strong resistance from indigenous groups. Such activities are widespread but, while they provide benefits to rural people, they do little damage to the ecosystem. The reserve managers also consider that using some reserve land for income-generating activities may be essential, as a way of taking pressure off other resources. In response, villagers collect a wide variety of products from XNR land, with no fear of fines or other punishment.

XNR managers require villagers to seek permission when collecting wood in the reserve, and require that a fee be paid for this right. This however becomes a disincentive to requesting permission, and thus results in illegal tree harvesting. Enforcement against such illegal harvest does not appear effective and few people have been caught redhanded (Albers and Grinspoon, 1997).

XNR managers also support or tolerate some income-generating activities, the conversion of shifting cultivation land to rubber and tea plantations, and the production of grains and other products on reserve land: for example, the cultivation of $A$ mommm villosum (a medicinal herb) within XNR, which occupies much of the shady riparian land in the reserve. As well as providing income for the local community, the cultivation of this plant also has an ecological value; for example, it requires tree cover and consistent water flows, and therefore depends on the protection of the nearby forest. Thus, a policy to provide economic benefits can develop support for certain con- 
servation objectives. A similar approach has been taken in the conversion of shifting cultivation land to rubber and tea plantations, which both generate more income than shifting cultivation, and incorporate soil management techniques. To support this conversion, XNR offered land for grain production in parts of the reserve so as to offset the loss in grain production from reducing shifting cultivation.

The XNR authority has also established a negotiation and permission system, based on need, which grants limited access to agricultural land in the reserve, while maintaining control over the extent and location of that land. This allows concessions for rubber and fruit trees on land in the reserve (Tisdell, 1995 cited in Albers and Grinspoon, 1997); a tractor road and reservoir in the reserve have also been constructed to improve the productivity of the agricultural plots within and outside of XNR. Ecotourism programmes have also been planned outside the reserve areas, including a joint venture between the reserve and the indigenous peoples.

The negotiation system in XNR incorporates local people's needs into management decisions, although local people are not involved in most of the decision process. XNR management uses village-level social pressure to protect the remaining reserve environment. The XNR management plan envisages the employment of local villagers from outside the reserve as guards.

\section{Critical evaluation of lessons learnt}

Before 1990, the national policy on ethnic minorities was to assimilate them into the mainstream society, a legacy from the times of Mao. Since 1990, a less repressive stance has been adopted towards most minorities, and there has been a certain growth in the strength and vitality of minority traditions in areas of religion, art and language (Sofield and Li, 1998). XNR's management reflects this new policy. Since 1994, XNR management has taken a people-centred approach to achieve conservation based on economic realities. This is very different compared to that followed in other protected areas in China where park management is still based on more rigid rules. As a result, indigenous communities are now more supportive towards the XNR management. However, any future relocation projects may be met with considerable resistance from local villagers.

But, of course, with this liberal attitude towards indigenous communities, the protection of threatened and endangered species may be jeopardised. Indeed, mainstream conservationists could argue that biodiversity has already been seriously compromised in favour of economic opportunities. However, given the changing realities in China, and because ethnic minorities have long been economically disadvantaged, the current management policy in XNR may be justified in terms of opportunities for improved livelihoods, and building support for strict conservation policies in parts of the reserve. Also, because of the new economic opportunities, such as rubber and camphor plantation, indigenous communities now depend less on the resources available inside the reserve. Indeed, many villagers have reported that, because of their engagement in plantations, they find very little time to venture inside the reserve in search of forest products (Albers and Grinspoon, 1997). The same applies to subsistence hunting, although illegal hunting continues to be a problem in XNR.

Problems have also arisen over the adoption of conservation activities by the indigenous communities. For example, XNR provides seedlings to the communities for agro-forestry on village land so as to meet susbsistence needs for fuelwood and timber 
(Tisdell, 1995 cited in Albers and Grinspoon, 1997). Despite warnings by village elders of future shortages of fuelwood, local communities have shown little enthusiasm for tree planting. Being close to the reserve and its forests, they do not have a sense of forest resources being scarce. They prefer instead to use their own land to earn income. Also, because the new rubber plantations increase the value of land, there is little incentive to convert to fuelwood production.

Despite the commitment of XNR management to improving relations with indigenous communities, questions of sharing power and decision-making have not yet been addressed. Given the Chinese context, it is perhaps unlikely that this will happen soon.

\section{Major challenges for the future}

Recent developments in XNR indicate some positive trends in community-oriented resource management. XNR's "interactive management" is better positioned to deal with conflicts over access to resources in the reserve than traditional approaches. Since only a small amount of China's land area is protected in its reserve system, the value of XNR is particularly important. Unfortunately it is also at risk. The question now is whether the reductions in the level of protection in XNR which have been permitted in order to encourage economic development will create enough economic growth and goodwill to enable XNR managers to prevent further conversion of reserve land to non-preservation land uses. The outcome may be affected by China's broader economic reforms, which will create a different context in which to assess the incentives needed to persuade people to respect the reserve's resources. In any case, successful protection of the reserve will ultimately depend on a mix of incentives (local involvement, community resource management, ecotourism) and disincentives (strict enforcement of certain regulations).

\section{References}

Albers, H.J. and Grinspoon, E. (1997). A comparison of access restrictions between Xishuangbanna Nature Reserve (China) and Khao Yai National Park (Thailand). Environmental Conservation 24: 351-62.

Grinspoon, E. (1996). The political ecology of forest conservation in Xishuangbanna. China (parts I and II). Chinese Environmental Histon Newsletter 3: 6-9 and 16-19.

IUCN (1993). Nature reserves of the Himalayas and the mountains of Central Asia. Oxford University Press.

Nepal, S.K. and Weber, K.E. (1995). Managing protected areas under conditions of conflict. Selected case studies from China, Myanmar, Nepal. Philippines, and Thailand. Unpublished research report submitted to the International Development Research Centre (IDRC), Canada. 225pp.

Santiapillai, C., Dong, Y.H. and Li, Y. (1990). Management of elephants in Xishuangbanna Nature Reserve, P.R. China. WWF Report No. 3194.

Shi, Y. (1980). The utilization and conservation of natural resources in Xishuanghanna. Natural Resources 2: 84-9. 
Sofield, T. and Li, F.M. (1998). Tourism development and cultural policies in China. Annals of Tourism Research 25: 362-92.

Tisdell, C.A. (1995). Issues in biodiversity conservation including the role of local communities. Environmental Conservation 22: 216-28. 


\section{Case study 10}

\section{Kytalyk Resource Reserve, Russian Federation}

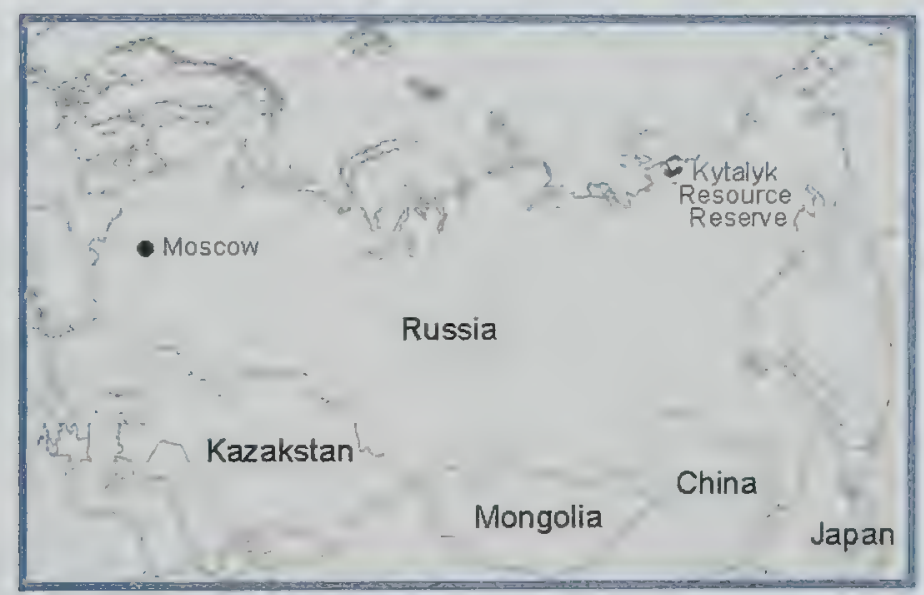





\section{Case study 10}

\section{Background information ${ }^{11}$}

Kytalyk Resource Reserve, or Zakaznik, (KRR) is located in the high arctic region of north-east of Russia. KRR is situated in the Yana-Indigraka lowland, between the Khroma and Indigirka rivers which drain into the Arctic Ocean to the north. The protected area borders the Laptev Sea to the north-west and the Siberian Sea to the north-east. The Polousny Mountains are situated to the south-west. The co-ordinates of the reserve are $70^{\circ} 46^{\prime}-72^{\circ} 20^{\prime} \mathrm{N}, 143^{\circ} 35^{\prime}-152^{\circ} 30^{\prime} \mathrm{E}$.

Located within the Arctic Circle, the reserve is dominated by tundra: more specifically it falls into a "typical tundra subzone" (Chernov, 1988). This subzone is the most characteristic of the relatively uniform, treeless tundra landscapes, and consists of gently rolling relief, with stable vegetation cover on watersheds. River valleys, steep shorelines, lake basins and boggy depressions break up this monotony, as does the local presence of "polygonal" or "spotted" tundra, a feature which is caused by repeated freezing and melting. The landscape is interspersed with lakes and wetlands, while the north-east of the reserve encompasses the Indigirka River delta.

Trees and small bushes are absent on the watersheds, with the height of vegetation determined by the thickness of annual snow cover. Bryophytes are common with 10 species predominating. Sedges are abundant, forming the bulk of the herbaceous layer. Typical tundra may also comprise bushy willows, shrubs and dwarf shrubs (e.g. dwarf species of Salix, Dryas, Cassiope and Vaccinium). Cotton-grasses Eriophorum spp. and dicotyledonous herbs such as Saxifraga, Pyrola and Compostiae are also common.

The Yana-Indigirka lowland, within which the reserve is situated, is home to a population of approximately 130,000 wild reindeer Rangifer tarandus, primarily located on the western bank of the Indigirka River. It is also home to the largest mass moulting of geese in the Yakutia Region. Bean goose Anser fabalis and white-fronted goose Anser albifrons number up to 30,000 birds. Other important bird species in the area include spectacled eider Sommateria fischeri (VU), king eider Sommateria spectabilis and Ross's gull Rhodosthetica rosea.

The region, and particularly the Yana-Indriraka lowland, is the breeding ground of the Eastern Siberian population of the Siberian crane Grus leucogeranus (EN) - "Kytalyk" is the Yakutian name for the Siberian crane. Breeding grounds for the species are typically located in lowland tundra (moss-lichen tundra and sedge dominated wetlands). more rarely in the forest-tundra transitional zones and sometimes in the northernmost taiga (forest zone) between the Arctic Ocean and the uplands to the south. Considered a sacred bird by the Yakutians, the Siberian crane is the third rarest of all cranes. These birds are threatened by habitat loss through land drainage and reclamation, agricultural development and oil exploitation activities. The eastern population are believed to

${ }^{11}$ Case study prepared by G.Smith, UNEP-WCMC 
number 2,900-3,000, representing $99 \%$ of the world's total population. More than 800 cranes are believed to nest in the reserve.

The establishment of the reserve has been as a result of collaboration between the government of the Sakha Republic and WWF. Initially, in the early 1990s, two relatively small local zakazniks (resource reserves) were established to help conserve the crane populations. As a result of Government Decree No. 337, (of 12 August 1996), the reserve was established over $24,911 \mathrm{~km}^{2}$. In January 1999 , its area was extended by $8,852 \mathrm{~km}^{2}$, and KRR is now one of the largest reserves within the Russian Arctic. The creation of the reserve in its present form is largely a result of biological research undertaken by Dr. Nikolai Germogenov, an ethnic Evenk familiar with the lifestyle of the indigenous communities of the area, and funded by WWF-Germany.

\section{Indigenous/Traditional people(s)}

KRR is located in Allaikhovsky Ulus district in the north-east of the Republic of Sakha (Yakutia), Russia. This district extends over $107,400 \mathrm{~km}^{2}$, while Yakutia covers $3,103,200 \mathrm{~km}^{2}$, approximately $18.2 \%$ of the Russian Federation. Three communities of Even people inhabit the reserve, a native people who traditionally engage in reindeer herding and husbandry, fishing and hunting. These communities have been actively involved in the establishment of the reserve.

49 indigenous peoples and ethnic groups have been identified in Russia (Murashko, 1998), of which the Even are one. In the 17th century, the Russians referred to this group as the Lamuts: the Even word "lamu" means sea or lake. Originally believed to be a subgroup of the Evenk, the Even (the reindeer people) are descendents from a mixture of Tungas and Yakagir cultures. Tungas nomads (in the Yakut language tongus), is a general name that covers a great number of native tribes that populated central and eastern Siberia from the Pacific shore, deep into inner Asia. By the 18th century a splinter group of these people, the "Lamut Yakagirs", began to migrate towards the Sea of Okhotsk. This group eventually became known as the Evens, while those left behind were identified as the Evenk.

The Even inhabit a huge territory in north-eastern Siberia, extending east of the Lena river to the Sea of Okhotsk, and to the Arctic Ocean in the north. Populations live in several specific areas in this part of Russia, including a large territory in the Khabarovsk district, the Magadan region, the northern part of Yakutia, the Chukchi and the Kamchatka Peninsula. The group's formation and wide distribution is believed to be connected to their constant migration over the centuries. Moving north and east, the Even have assimilated and been influenced by a number of different cultures including the Koryaks (Kamchatka), Chukchi (Chukchi Peninsula), Yukaghir (Kolyma River basin) and Yakuts. The group has a designated national district in Yakutia, the EvenBytantai.

The people have several self-designations, of which the best known is Even; in 1930 this became their official designation. Some groups, however, call themselves oven or orochel "the reindeer people".

The Even are believed to belong to the Baikail (Paleo-Siberian) group of peoples, similar to that of the Evenk. The Even are however smaller and have a lighter skin tone than the Evenk. The populations of both groups have declined over the centuries, due to pressure from ethnic Russians. They have tried to maintain the Tungus culture (nomadic existence), but not always with success. 
Over the past 300 years, state policy pertaining to indigenous peoples of Russia has undergone major changes. It has altered from a policy of non-interference and respect for the traditional way of life of native groups, to attempts at total integration and modernisation of their lives. In particular, following the Russian Revolution in 1917, dramatic changes occurred in the nomadic lives of the indigenous peoples of the Soviet Union, such as the Evens. During the early years of Soviet rule, the Even were forced to form tribal councils and executive committees to govern their affairs. Soviet ideology was introduced and explained by propaganda centres known as "Red tents". Forced collectivisation began in 1929, in north-eastern Siberia. Collectivisation of the Even on the coast of the Okhotsk Sea was completed by 1936, bringing about unprecedented changes in the distribution of the people. New dwellings and schools of Russian style were built in village centres, and new methods of agriculture were introduced (cattle rearing and land cultivation). However many Even and Evenk communities resisted, by destroying their herds and fleeing their territories.

Pressure on the Even increased after the discovery of gold in the region in 1931-1932. Ethnic Russians used many of the indigenous inhabitants as cheap labour and requisitioned their reindeer for transport. The entire valley of the Kolyma River was transformed into a zone of gold-mining, logging and prison camps. Further changes were brought about by the relocation of Soviet industry east of the Ural Mountains, preand post-World War II. State-run mines and industrial zones covered many traditional hunting and grazing areas and caused widespread environmental destruction. A further influx of ethnic Russians placed pressures on local communities, who were susceptible to introduced disease. Many Even communities dispersed still further north to avoid contact with the Russians. As a result, Even culture has been badly damaged, according to the "Association of Native People of Chukotka and Kolyma".

The Even language is one of the northern group of the Manchu-Tungus languages, a group which also includes the Evenk and Negidal languages. It has much in common with the Evenk language, which itself shares similarities with Mongolian and Turkic languages. Often considered a dialect of the Evenk language, Even differs from it in terms of phonetics and vocabulary. Even itself is divided into two main dialects (eastern and western), as well other minor dialects such as the "Arman". The written version of Even is based on the eastern, Oli dialect.

Despite the publication of a number of comprehensive works in the Even language (the first book were published in 1932), its use remains relatively limited. It is particularly difficult to implement in schools, due to the mixed nationalities of pupils. According to the 1959 census, $81.4 \%$ of the Evens were native speakers, but by 1979 this had dropped to $56.9 \%$. In $1979,71.8 \%$ of the Even population spoke Russian fluently. and $19.9 \%$ considered it to be their mother tongue. Of the approximately 10.500 Even who live in Yakutia (1996 estimate), some $70 \%$ speak the Yakut language and only $35 \%$ speak their own language. In such a situation, the opportunities for sustaining or developing ethnic culture are limited.

Recent changes in Russia have affected the Even. Thus a law on "The legal status of the minor indigenous peoples of Russia" was adopted by the State Duma in 1992. However it has not yet been accepted by the Fecieration or the President. Articles within the "Land Code", "Law of the Russian Federation about environmental protection", "Law on protected territories" and "Principles of Forest Legislation" include special rights for indigenous peoples regarding the exploitation of natural resources. In 1901. the republics of Buriatia, Sakha (Yakutia) and Karelia, as well as the autonomous arcas 
of Koryakskiy and Khanty-Mansiyskiy, adopted their own legislation regulating the rights of indigenous peoples and the utilisation of natural resources.

Over the past decade, too, the indigenous peoples of Russia have begun to mobilise themselves into a political force. Following the 1990 Congress of Northern Ethnic Minorities (in which there were 16 Even among a total of 341 delegates), several public organisations of peoples of the north have been established. These include the Association of the Peoples of the North (APN), set up in 1990, the Deputy Assembly of minorities of the North, Siberia and the Far East (1991) and the International League of Minorities and Ethnic Groups (1991).

\section{Involvement of the indigenous peoples in the management and administration of KRR}

Following the dissolution of the Soviet Union in 1991 and the political reforms that resulted, there have been big changes in Russian environmental and protected area policy and law. The basic legislation currently governing protected area organisation, protection and use is the "1995 Federal Law on Specially Protected Areas" (SCEP, 1997). Through this law, protected areas are defined as objects of national wealth, and designated into the following main categories:

\section{Zapovedniks (strict reserves)}

National Parks

\section{Zakazniks (reserves)}

\section{Natural monuments}

Under this law, strict reserves (zapovedniks), are defined as "nature-protection, research and eco-educational institutions designed for the preservation and investigation of nature processes and phenomena, the gene pool of plants and animals, certain species and communities of plants and animals, typical and unique ecological systems". National Parks are defined as "nature conservation, eco-educational and research institutions whose terrestrial and water areas include nature complexes and features of particular ecological and historical and aesthetic value and designed for the use for nature conservation, research and educational purposes and also for regulated tourism". The principal objective of zakazniks is the long-term preservation and protection of habitats of especially valuable game in order to enrich the fauna of adjacent lands. They may have federal or regional significance. Natural monuments are for the protection of individual natural features.

Until very recently, the management of the majority of Russia's most strictly protected areas (zapovedniks) was the responsibility of the Russian Federation State Committee on the Environment (RFSCEP), or Goscomecologyia ${ }^{12}$. However, other bodies such as the State Committee on Forestry (Forest Service) or Rosleshoz, the

\footnotetext{
${ }^{12}$ Under a decree of Russian President V. Putin, no. 867, dated 17 May 2000, "On the Structure of Federal Bodies of Power", the State Committee for Environment Protection, ceased to exist. Simultancously, the Federal Forestry Service, responsible for the protection of Russian forests, was also abolished. The authority of the abolished committees was transferred to the Ministry of Natural Resources of the Russian Federation (MNR), which licenses development of Russia's oil, natural gas and other deposits. Responsibility for the overall management of protected areas is unclear at present.
} 
Russian Academy of Sciences (RAS) and the Ministry of Education have jurisdiction over some areas. National parks are gencrally under the jurisdiction of the Forest Service, while most federal zakazniks are managed by the Department on Protection and Rational Use of Hunting Resources, under the Ministry of Agriculture (SCEP, 1997).

Sakha (Yakutia) is a Presidential republic with its own constitution. It was first granted the status of an autonomous republic in 1922, and currently has a bicameral legislative system. There are 16 ministries and eight national committees, including a Ministry of Nature Protection (Argounova, 1994). The exact role and responsibilities of this ministry in relation to the establishment of protected areas is unclear.

Indigenous communities are often extremely cautious about the establishment of new protected areas, mainly for fear of additional inspections that would interfere with, and disturb their traditional lifestyles. KRR is considered unique in that the three groups of Even reindeer breeders that inhabit the area were involved in its establishment. Six specific management zones have been established, which offer varying degrees of nature protection to exist alongside specified traditional activities of the Even. These zones are:

Zone 1: Seasonal zone: available to the indigenous population for hunting in the winter. Huts in the zone contain fishing nets and traps. In summer the area is closed to human access. It functions as a zone of absolute protection for the nesting of Siberian crane.

Zone 2: $\quad$ Established as a zone of traditional nature use for territories with lower concentrations of Siberian crane nests. Reindeer hunting and breeding, grass collection and eco-tourism are permitted. However, hunting for waterfowl and entry by people who do not conduct traditional nature use activities, are prohibited.

Zone 3: Sacred land zone, which protects the world famous "Berelyakh" mammoth cemetery. Following earlier damage to the site by tourists and merchants, the indigenous communities of the area specifically requested this protection.

Zone 4: A zone for licensed hunting for wild reindeer. The area is located within the traditional hunting areas of one of the three Even communities.

Zone 5: A small zone for licensed fishing.

Zone 6: Includes coastal sites of the Eastern-Siberian Sea, including the Indigirka River delta. This zone is reserved for protection but may be further divided into new zones with different protection regimes following closer study.

Development activities, such as exploration and exploitation of minerals and infrastructure construction, are prohibited throughout the reserve.

The establishment of KRR has involved leaders from the local tribal communities and the district administration. The support of Mr Semyon Rozhin (Head of Administration of the Allaikhovsky Ullus) was a particularly important factor. Dr Nikolai Germogenov (see above) has been an active participant in the establishment of this reserve following extensive personal biological research in the area. More specifically he has been the project leader on behalf of WWF. The promotion of nature conservation work at local meetings has been an important part of this project. 
The reserve's activities are determined by a Trustee Co-ordinating Council, formed in 1997, which consists of representatives from the reserve administration, indigenous communities, the Yakutian Ministry for Nature Protection, and scientific and nature conservation organisations. Representatives of each of the three Even tribal communities are included in the reserve's protection service (ranger service). While offering employment opportunities, this also provides a valuable communication link between park authorities and the local indigenous groups.

As a result of the establishment of specific management zones within the reserve, the Even communities inhabiting the area appear to obtain many benefits from the protected area. These include preserving valuable ecosystems and their associated wildlife, as well as ensuring the development and preservation of traditional cultural practices and other ecologically safe forms of natural resource use.

\section{Traditional knowledge and practices}

During the early part of their history, the Even hunted moose, wild reindeer, musk deer, mountain sheep and bear. Dogs were often used for hunting (known as Lamut dogs in Kamchatka), with their favourite technique being the driving hunt. Essentially a nomadic people, the Even's economy was traditionally based on hunting and rearing of wild reindeer. Later they began to domesticate the reindeer. As a result, they - and the Evenk - differ from many other hunting peoples of Siberia and the Far East in that they are both hunters and reindeer herders.

Indeed, reindeer hunting and breeding has for long been central to the group's existence. The annual reindeer migration was the main event of Even life, with the species (the same as the North American caribou) moving north to higher, cooler altitudes in the summer to avoid insects and then migrating towards greater tree cover and adequate food supplies in winter. The Even followed the reindeer, and their entire culture was built around the nomadic lifestyle, living in temporary (urikit) or permanent (meneen) camps, as well as in light, portable, conical tents (chums) during the hunt.

Reindeer played an integral role in the lives of the Even, providing hides for clothing and house coverings; hair, bones, and antler for the manufacture of tools, ornaments and works of art; sinew and tendons for ropes, cordage, and thread; the means of nonpedestrian transport; and as central figures in ritual and ceremony. The use of reindeer as baggage-carrying and riding animals by the Even is unique among indigenous groups of the region. Reindeer were only used for this purpose when migrating to a new place. The animals grazed freely but were milked by the Even.

While most Even communities were nomadic, there were also some more sedentary groups, with reindeer pastures in the river basins of the Kolyma, Omolon and Indigirka. In these locations, fishing was an additional summer occupation. Groups of Even inhabiting areas close to the Okhotsk Sea did not breed reindeer, but were fishermen and hunted sea mammals. Such communities used dogs as draught animals.

Traditionally, the Even, like the Evenk, hold a number of spiritual beliefs such as totemism, which involves the animation of natural phenomena and concepts of the soul. Magic rites were associated with this belief, relating to the hunting or guarding of reindeer herds. Over time, such rites came to be administered by shamans. Shamanism has been considered as the faith of the Even. Indeed the word "shaman" originates from 
the Evenk language, and is used to describe a religious specialist from the Siberian region. The magic rites of totemism were further developed through shamanism, which invoked guardian spirits to see off the spirits of the deceased, to dedicate reindeer, and spiritually to purge the hunters. Elements of the bear cult may also have influenced the faith, including the dressing of the carcass of the bear, consumption of its meat and burial of its head and bones.

Shamanism is not a single, unified religion but a cross-cultural form of religious sensibility and practice. Many current interpretations emphasise the healing side of shamanism, but this is only one aspect of the shaman's work. Among other things, shamanism is a hunter's religion, concerned with the necessity of taking life in order to survive. The shamanic view is based on the idea of paying for the souls of the animals one needs to eat.

Following the Evens first encounter with the Russians in the 1600 s, the Russian Orthodox Church strove to convert them to the Christian Faith. According to the 1987 National Census data, a significant proportion of all Even were recorded as Orthodox Christians. However it is unclear how accurate this figure is, as some records state that Christianity has only been accepted nominally, with conversions remaining relatively superficial.

As noted above, KRR has a specific "Sacred land" zone, the site of "Berelyakh" mammoth cemetery, which was formerly plundered by merchants and tourists.

\section{Critical evaluation of lessons learnt}

It would appear that the establishment of KRR is a good example of successful collaboration between government and protected area authorities, an international NGO (WWF) and an indigenous peoples group. While the project has been successful so far, the establishment of the reserve is still in its early stages. A continued commitment to collaboration will be needed to ensure that effective management continues, satisfying both the Even's cultural and economic needs and the area's wider nature conservation requirements.

\section{Major challenges or directions for the future}

Russia and its outlying republics continue to undergo major political, economic and social change. In many parts of the country the development and exploitation of natural resources such as oil and gas continue rapidly and with minimal environmental and other restraints. In the face of such pressures, the creation of protected areas to preserve valuable habitats and ecosystems, endangered wildlife populations and traditional native cultures is vital. Collaboration between government departments responsible for the designation of protected areas and other relevant parties, notably indigenous communities, should continue to be encouraged and developed: KRR provides a model of how such a relationship can be developed. 


\section{References}

Argounova, T. (1994). Republic of Sakha (Yakutia). Scott Polar Research Institute, University of Cambridge. Website: http://www.spiri.cam.ac.uk/rfn/sakha.htm.

Chernov, Y.I. (1988). The Living Tundra. Cambridge University Press, Cambridge, UK. 213pp.

Murashko, O. (1998). Indigenous Peoples and Conservation of their Environment in Russia. IWGIA, Moscow. 12pp.

State Committee of Russian Federation for Environment Protection. (1997). First National Report of the Russian Federation: Biodiversity Conservation in the Russian Federation. State Committee of Russian Federation for Environment Protection, Moscow. 170pp. 


\section{Case study 11}

\section{Kakadu National Park, Australia}

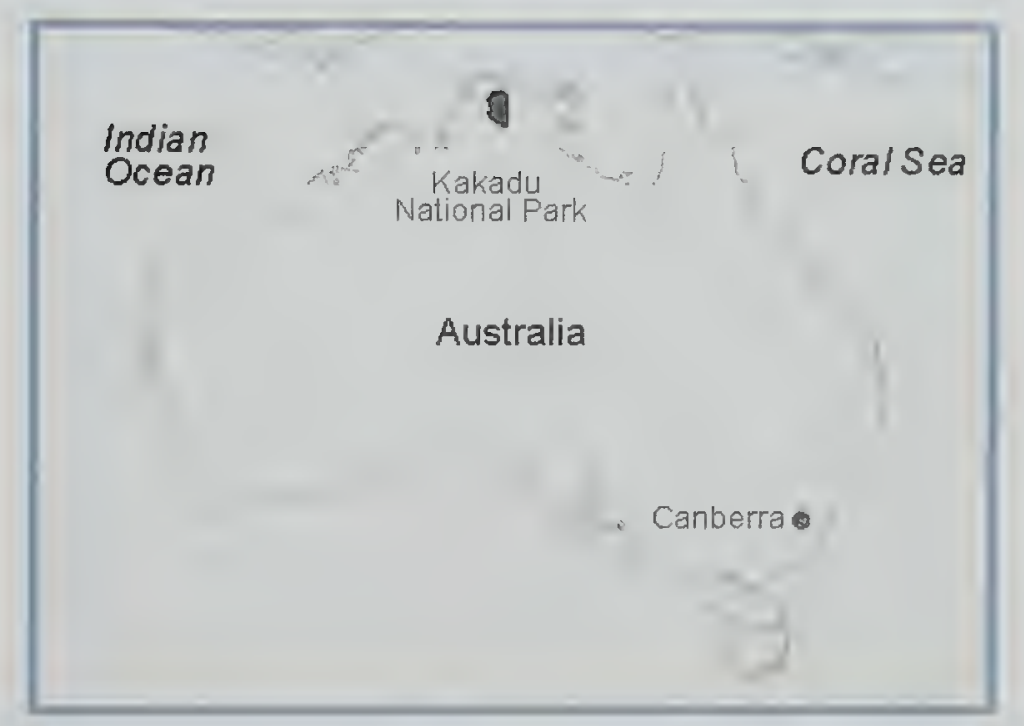





\section{Case study 11}

\section{Background information ${ }^{13}$}

Kakadu National Park (KNP) is located approximately $200 \mathrm{~km}$ east of Darwin in the wet-dry tropics of the Northern Territory of Australia. The park covers an area of $19,804 \mathrm{~km}^{2}$; its location extends from the northern coastal area of the Van Diemen Gulf, generally south eastwards through floodplains to the lowland hills and basins some $150 \mathrm{~km}$ to the south, and from the saridstone escarpment and dissected Arnhem Land plateau in the east, $120 \mathrm{~km}$ to the western boundary with wooded savannahs and rivers. Its coordinates are $12^{\circ} 04^{\prime} \mathrm{S}-14^{\circ} 00^{\prime} \mathrm{S}, 131^{\circ} 52^{\prime} \mathrm{E}-133^{\circ} 00^{\prime} \mathrm{E}$.

Four major coastal rivers and their associated estuarine flood plains are included within KNP: the East Alligator, the South Alligator, the West Alligator and the Wildman, as well as a number of scattered creeks (Commonwealth of Australia, 1986, 1991). Other major landforms and habitats include: the western rim of the Arnhem Land sandstone plateau and escarpment complex, with spectacular waterfalls (such as Jim Jim Falls), overhangs and caves, with escarpments ranging in height from about 30 to $330 \mathrm{~m}$; a series of undulating lowland plains (a formation known as the Koolpinyah surface) which stretch from Darwin to the Arnhem Land complex; and the southern hills and basins, which form a complex of rugged and gently sloping topography.

The Alligator Rivers region within the park is one of the most floristically diverse areas of monsoonal northern Australia. More than 1,600 plant species have been recorded, reflecting the variety of major landform types and associated plant habitats in the region. The vegetation can be classified into 13 broad categories, seven of which are dominated by a distinct species of Eucalyptus, typically with a tall $(1-2 \mathrm{~m})$ grassy understorey, and comprise the dominant vegetation in the park, (DASETT, 1991).

The scientific and conservation value of the park's fauna is of national and international significance. The 64 native mammal species known from the park comprise more than one-quarter of the total number of known terrestrial mammal species in Australia, and include 26 of the 65 species of Australian bats. Mammals include dugong Dugong dugon (VU), ghost vampire bat Macroderma gigas (VU), orange leaf-nosed bat Rhinonicteris aurantia (VU), golden-backed tree-rat Mesembriomys macrurus (VU) and Northern quoll Dasyurus hallucatus. There are 128 reptile species, the most notable being loggerhead turtle Caretta caretta (EN), green turtle Chelonia midas (EN) and hawksbill turtle Eretmochelys imbricata (CR). The 274 species of bird fauna makes up $33 \%$ of all those found in Australia (Commonwealth of Australia, 1986; DASETT, 1991).

KNP has been assigned to the IUCN Management Category II. The park was established in three stages. Woolwonga Aboriginal Reserve and Alligator Rivers

${ }^{13}$ Case study prepared by S.Grady, UNEP-WCMC 
Wildlife Sanctuary and Protected Areas were incorporated into Stage I, which was proclaimed on 5 April 1979. Stage II was proclaimed on 28 February 1984, and gazetted on 20 December 1985; this excluded an enclave containing the Ranger and Jabiluka uranium mineral lease areas. Stage III was proclaimed in three successive phases on 12 June 1987, 22 November 1989 and 24 June 1991, further increasing the size of the park, as areas of a former Conservation Zone were added.

KNP was inscribed on the World Heritage List as a mixed property in three phases: Stage I in 1981, Stage II in 1987 (again excluding the enclave containing the uranium mineral lease areas) and Stage III in 1992. Additionally, Stages I and II were designated as Ramsar sites in June 1980 and September 1989, respectively (Commonwealth of Australia, 1986; DASETT, 1991).

Approximately $50 \%$ of the land in KNP is held as inalienable freehold land by Aboriginal groups.

\section{Indigenous/Traditional people(s)}

It is believed that the first Australian Aborigines reached the country during the last ice age, northern Australia being the "beach head" for this colonisation, either in the Kimberly region to the west or the Arnhem Land of KNP in the east. Using the most recent dating techniques, evidence was recently discovered of human occupation dating back 50,000 years in the Kakadu region (Commonwealth of Australia, 1999a).

Historically, the Aborigines lived in shelters made of bark or stone, and existed as hunter-gatherers. They had a transient way of life, travelling to find sources of food, rather than growing crops or herding cattle. Each group (or clan) had its own tract of land from which to hunt and gather resources, and they moved between regular, semipermanent living areas to wherever the resources were most abundant (Davies et al., 1999). It is claimed that the Chinese, Malay or Portuguese may have been the first to make contact with them, but contact between the Aborigines and Macassans (sailors from Sulawesi) certainly occurred from the 17 th century onwards.

The first historical evidence of European contact with Aborigines in Kakadu is by the Dutchman, Carstenzoon, in 1644. During these early contacts, their culture and traditions remained fairly unaffected. This eventually began to change in Australia from the period of European settlement in 1788, when British Governor Philip and his fleet first arrived. Governor Philip applied the terra nullius doctrine to the country. At this time there were an estimated 300,000 Aborigines in Australia. But it was not until the late 1830 s, when British occupation of the north became more permanent that a marked effect on the Aborigines living in the area took place. As settlers moved in, they began to possess the land and deny the rights and freedom of the Aborigines. In the subsequent decades, the Aborigines were treated as outcasts, and many were shot or poisoned. In the same period, mining, buffalo hunting (an introduced species in the area) and pastoral activities had a significant impact on the Aborigines and their landscape (Commonwealth of Australia, 1986; Lam, 1997).

From the early 1900s, attempts to segregate the Aborigines were made. Under the Aboriginals Ordinance of 1918, only "full-blooded" Aborigines were permitted to live in reserves. From 1910 to 1970, the Australian Government actively forced the assimilation of Aborigines into the European culture. An unknown number of children, 
especially of mixed ancestry, were separated from their families under various State and Territory welfare laws, believing that a European-style upbringing was in their best interests. This policy was deemed a failure in the 1960s: it was finally stopped in 1972 and replaced by the policy of self-determination (Lam, 1997).

On 27 May 1967 in a constitutional referendum, 91\% of the indigenous and nonindigenous population voted to give the Australian Government power to legislate in favour of the Aboriginal Australians, and, for the first time since European settlement, they were treated fairly and allowed to make decisions (Commonwealth of Australia, $1999 \mathrm{~b}$ ). The Aborigines were finally given back all their reserves and mission lands under the Aboriginal Land (Northern Territory) Act 1976. This Act also provided the opportunity for Aborigines to claim their native land.

When the first European settlers came to Kakadu, it is estimated that the Aboriginal population was 2,000 , but this number was greatly reduced by the 1920 s following social dislocation and disease (Hill and Press, 1994). When KNP was created in 1979, there were only 139 Aborigines living within its limits. This rose to about 250 by 1986 . By 1996, the population had grown to 533 (Commonwealth of Australia, 1986; 1999a). The township of Jabiru, which was initially built to cater for the workers associated with the uranium mining activities in the region, now has a population of 1,480 (mainly nonaboriginal occupants), rising from an estimated 1,200 in 1991 (Commonwealth of Australia, 1991).

At the beginning of the 20th century, the main Aboriginal language used in the northern part of the area was "Gagudju", from which the name Kakadu came from. It is believed that the Gagudju-speaking Aborigines were the original inhabitants of the region (Lam, 1997). There are now three major Aboriginal languages spoken within KNP, namely Jawoyn, Gundjeihmi/Mayali and Kunwinjku. The word for Aboriginal people in the Kunwinjku and Gundjeihmi languages is Bininj, and Mungguy in Jawoyn. There are other, less prominent Aboriginal languages used in the park such as Limilngan - their word to describe Aboriginal people is Murlugan (Commonwealth of Australia, 1997). There are about 16 extant clans of traditional owners that are widely scattered throughout the park, the greater number of these being located in the north-eastern part. There are also approximately 13 other traditional clans located just outside the park's eastern boundary (Commonwealth of Australia, 1999a).

In 1972, the Commonwealth of Australia established, for the first time, a department whose sole responsibility was to deal with Aboriginal matters, but to the present day the institutional situation of Aborigines within Australia remains complex, including in respect of protected areas. The major reason for this is the wide difference in management structures (or the lack of one in some cases) for indigenous peoples and their involvement in protected areas in each of the eight states and territories. Despite this, since the 1970s various indigenous organisations, as well as the Commonwealth, State and Territory governments, have helped determine the legal rights of Aborigines, the exercise of land rights and management of wildlife (Commonwealth of Australia, 1999b; Davies et al., 1999). The main reasons for Aboriginals to press land claims have been to gain legal recognition of traditional land ownership, to be able to pursue a traditional lifestyle, for the restoration of spiritual and cultural links with their land, and for the general promotion of their self-determination. By 1999, 14\% of Australia was officially recognised as land owned by indigenous peoples (both Aborigines and Torres Strait Islander people). Much of this land is concentrated in remote arid and northern tropical areas. 
The "Mabo" decision, established in 1992 in Australia's High Court, created the common law rights of Australia's indigenous people's land, referred to as "native title" (Davies et al., 1999). This finally overturned the doctrine of terra mullius, previously used to justify the loss of traditional lands and seas of the indigenous peoples. The "Mabo" decision established that "native title" rights exist where indigenous people have maintained their traditional connection with the land (e.g. traditions, laws and customs) and where their "native title" has not been extinguished through previous government actions (Davies et al., 1999).

In 1993, the Native Title Act was established, and the new Act of 1998 additionally recognised that native title could co-exist with other rights on the same land, such as pastoral leases. The Australian Government has a continuing commitment to help indigenous peoples gain official native title, by being able to demonstrate their ongoing traditional association in the area. To this end, expenditure on land and native title issues in 1999-2000 (excluding native title payments to the States and Territories) is estimated to reach \$A216 million (Commonwealth of Australia, 1999b).

\section{Involvement of the indigenous peoples in the management and administration of KNP}

Each of the eight states and territories of the Australian Commonwealth has jurisdiction for the management of its own land and territorial sea, but it is the Commonwealth itself that holds the constitutional powers and responsibility for Aboriginal affairs. At the Commonwealth Government level, management of protected areas is now undertaken through the Biodiversity and Marine Groups of Environment Australia. By ratifying most international conventions which are relevant to indigenous human rights and conservation, and by developing appropriate Commonwealth legislation (e.g. Racial Discriminations Act 1975), the Commonwealth Government has strengthened its authority over state and territory powers affecting indigenous peoples rights and conservation (Davies et al., 1999).

The main piece of Commonwealth legislation that provides for the establishment and management of protected areas in its jurisdiction is the National Parks and Wildlife Conservation Act 1975. This Act enables the creation of protected areas with various designations. Following proclamation, responsibility for management lies with the Director of National Parks (a position within Environment Australia's Biodiversity Group). To assist the Director with this responsibility, the Australian National Parks and Wildlife Service (ANPWS) was set up and renamed in 1993 as the Australian Nature Conservation Agency (ANCA), later to become Parks Australia, and arm of Environment Australia. On 1 July 2000, the 1975 Act was replaced by the Environment Protection and Biodiversity Conservation (EPBC) Act 1999. This new Act recognises the critical role that indigenous people have in the conservation and sustainable use of ecological resources, and in holding traditional knowledge. In order to gain full benefit from the experience of the Aboriginal people, the EPBC Act will: (1) establish an indigenous Advisory Committee to advise the Commonwealth Environment Minister; (2) provide for indigenous representation on the Biological Diversity Advisory Committee; and (3) ensure that indigenous interests are addressed when developing bilateral agreements, management plans, recovery plans, wildlife conservation plans and threat abatement plans. 
Environment Australia administers the National Reserve System Programme (NRSP), established in 1996/97. This programme is a response to the National Strategy for the Conservation of Australia's Biological Diversity, which called for a system of protected areas based on the principles of "comprehensiveness", "adequacy" and "representativeness", as well as the biodiversity conservation value of the candidate areas. The programme includes these objectives:

[- the establishment and management of new, ecologically significant protected areas as additions to Australia's terrestrial National Reserve System;

the provision of incentives for indigenous people to participate in the National Reserve System, through the voluntary declaration of protected areas on their lands (Indigenous Protected Areas);

e support for greater involvement of indigenous people in the management of existing national parks and other protected areas;

- the encouragement of indigenous groups to manage land for biodiversity conservation.

The last three objectives represent milestones in Australia's indigenous affairs policy. This is the first time that Aboriginal organisations have participated actively in conservation planning with the support of government funds (Environment Australia Online, 2000).

The Conservation Commission Act 1980 established the Conservation Commission of the Northern Territory (CCNT), but it was replaced by the Parks and Wildlife Commission Act in 1995 which established the new Parks and Wildlife Commission of the Northern Territory. Upon designation, land is held by the Conservation Land Corporation; the commission has to produce a management plan for it (Environment Australia Online, 2000; IUCN, 1992).

Despite its location, the KNP is not affected by the Northern Territory protected areas system legislation, but is the responsibility of Environment Australia. Kakadu is one of three national parks that are jointly managed by the traditional Aboriginal owners and the Federal Government's Director of National Parks. KNP was declared under the Commonwealth National Parks and Wildlife Conservation Act 1975 (NPWC Act); it is this Act, along with the Aboriginal Land Rights (Northern Territory) Act 1976, that provides the legal framework for the system of co-management of KNP.

The Aboriginal Land Rights Act was established following an inquiry in the early 1970 s into the issue of aboriginal land rights in the Northern Territory. Some land areas were immediately granted as title to the traditional owners, but the Act also provided a mechanism through which the Aborigines could claim title to other areas of unalienable crown land on the basis of traditional ownership (Hill and Press, 1994). As a result, some $42 \%$ of the Northern Territory has now been granted to Aboriginal Land Trusts (Commonwealth of Australia, 1999a).

The three principal mechanisms that provide for the involvement of traditional Aborigines in the management and administration of KNP are:

- the Kakadu Board of Management,

a the park management plan, and

a day-to-day two way formal and informal liaison between the park staff (some of whom are Aborigines) and the traditional owners. 
The Board of Management, set up in 1989, represents the interests and views of the traditional owners in the joint management of the park, and determines the policy for park management. At present, there are 14 Board members, ten of which are Aborigines, nominated by the traditional owners, and representing all the aboriginal people and major languages in the region. AIso on the board are the Director of the ANPWS, a representative of the $\mathrm{N} T$ tourism industry and a person prominent in nature conservation (Hill and Press, 1994).

The role of Aborigines in the management and administration of KNP is set out in detail in the management plan, the fourth version of which is currently in operation. There are three main aims in managing the park: i) conserving the natural heritage of Kakadu, ii) conserving its cultural heritage, and iii) respecting the interests of the Aboriginal traditional owners. The management plan shows the many ways in which the local Aboriginal owners can participate in park management. The plan describes how the living cultural traditions involve the Aborigines in "caring for country". Other issues dealt with in the plan are the protection of all Aboriginal interests, providing for tourists, and teaching people about the park.

Five local Aboriginal associations (Gagudju, Djabulukgu, Minitja, Gundjeihmi and Jawoyn) are set up within Kakadu, which represent the political interests of different clans, and oversee aspects of financial investment, local business and enterprise ventures and other services (e.g. healthcare, housing) for their members (Commonwealth of Australia, 1999a).

One of the most important management issues in the park is the role of fire, which is used to manage habitats, maintain the resources used by the Aborigines and prevent larger wild fires spreading throughout the park and across its boundary. Since the park was established, one of the management aims has been to promote and return to traditional ways of burning. The Aborigines will be fully consulted to help develop fire management programmes on their land, and traditional owners and other residents living in the park will be employed to implement these programmes.

Aborigines are also involved in managing the native vegetation structure and habitats, as their knowledge of the plants and habitats is critical for long-term management. The Aborigines are able to continue to practice their traditional rights of gathering native plants for food and making cultural artefacts. They are also encouraged and supported to use traditional skills in managing plants and habitats, hence maintaining the living cultural tradition of the park.

In accordance with the lease agreements, Aborigines continue to exercise their traditional rights to hunt and fish within Kakadu. They consult with Environment Australia to ensure that sustainable levels of different species are extracted, and are encouraged to use their traditional skills to manage and conserve these animals and their habitats. Management of feral animals is also required, including buffalo, cattle, pigs, cane toads, cats and dogs, all of which pose problems for the park's ecosystems (Commonwealth of Australia, 1997).

Community-based wildlife management (CWM) is an approach that is becoming increasingly popular in Australia, notably through the Landcare Movement. Indigenous CWM promotes the sustainable management of wildlife on indigenous-owned land. This is critical in order to maintain Australia's biodiversity, and vital for the continuation of one of the world's oldest cultural traditions of resource management. However, not all 
Australia's indigenous people find it acceptable that governments should regulate their use of wildlife, and the success of indigenous CWM also depends on there being funds available to government conservation agencies to regulate and enforce wildife controls (Davies et al., 1999).

There are many cultural sites of significance in KNP, which reflect and express Aboriginal religious belief. In line with ancestral obligations, access is restricted to certain sacred sites. Management of rock art is carried out by the Art Site Maintenance Team that employs relevant traditional owners (Commonwealth of Australia, 1997).

\section{Traditional knowledge and practices}

Many Aboriginal people in the park have long-established ancestral bonds with the area of Kakadu, and although there have been changes in their everyday lifestyle, traditional customs and beliefs are still of paramount importance. Aboriginal tradition is based on intricate relationship with the land, inter-linking the spiritual, economic and physical bonds. These very important spiritual beliefs are the cornerstone of Aboriginal society, centring on spirit beings from the creation era and the time of the first people, the Nayuhyunggi.

The Aboriginal people believe that during the time of the creation era, the ancestral spirit beings came up out of the earth and down from the sky, and travelled across the flat and featureless landscape, when no ordinary men or women were present. These beings then moulded the landscape into its present form, shaping, for example, the rocks, rivers and hills, and creating the first people, and all the animals and plants. They were also the source of songs, dances, designs and rituals, and thus are believed to form the basis of Aboriginal religious expression (Commonwealth of Australia, 1999b). When the creation finished, the spirit beings did not just disappear, but returned to their birth places, turning themselves into features such as rocks, caves, pools and rock art. These features are still believed to retain the creative power and energy of the spirits and are therefore treated as sacred (Jackman, 1988; Lam, 1997).

One of the most important aspects of Aboriginal tradition that can still be seen in the park is the largest, and possibly best preserved body of rock art in the world. Art was an integral part of the Aboriginal lifestyles, recording the history and beliefs of the land. There are estimated to be at least 15,000 rock art sites in the escarpment and plateau areas of the park, 5,000 of which have been recorded by park staff (Commonwealth of Australia, 1999a; Edwards, 1978).

There is a long tradition of Aboriginal use of plant and animal resources in the area. Plant and animal materials such as pandanus leaves, plant dyes, bark, sticks, feathers and shells are used for traditional art and craft activities. Other historic uses of plants and plant material were to make fish poisons, didgeridoos, canoes and cooking implements, as well as being used as medicines; many such uses and skills remain (Commonwealth of Australia, 1997).

For millennia, Aborigines have used fire to manage the landscape and to practise many aspects of their daily lives. Traditional uses of fire included making it easier to travel through the land, for communication and defence, to clear an area infested with pests, to concentrate and improve the visibility of their prey when hunting, and to flush out certain animals (Boekel, 1990; Commonwealth of Australia, 1997). 
The Aboriginal people associated with Kakadu hold a long tradition of fishing, hunting and gathering animals from the land and waters. A number of species are currently hunted for subsistence, including turtles, wallabies, fish and snakes. (Commonwealth of Australia, 1997).

There are three types of sacred sites in Kakadu. Ceremonial sites (kundjamun) are places where special secret initiatory rites take place (Boekel, 1990). The other two relate to Aboriginal beliefs about their prehistory during the creation era: djang ("sites of significance") and djang andjumun ("dangerous sites of significance") (Commonwealth of Australia, 1997; 1999a).

\section{Critical evaluation of lessons learnt}

There is no doubt that the joint management between the Commonwealth Government of Australia and the traditional Aboriginal owners of KNP is a successful collaboration. The system of the Aborigines leasing their land to the Director of National Parks for management within the framework of a national park is considered an excellent model from which to gain experiences for the successful management of other protected areas with indigenous residents. There are other examples of good interaction between the two groups: for example, indigenous peoples are increasingly called upon to play an active role in the use of fire for habitat management purposes, something which, in the past, was reserved to the park staff.

Despite these successes, park issues have often been affected by land use conflicts between different interest groups, particularly over mining rights. Historically, the relationship between the Northern Territory (NT) Government and the Commonwealth Government has been turbulent, because of the NT Government's opposition to the involvement of Environment Australia in the park, and because of their opposition to Aboriginal land claims and their involvement in the joint management.

\section{Major challenges or directions for the future}

Despite the success of the joint management agreement and their involvement in the Board of Management, Aborigines may fear that their influence could diminish in the future because of the pressures upon the park, e.g. in respect of mining and the growth of tourism (World Heritage Committee, 1988; Commonwealth of Australia, 1997). An important challenge therefore is to ameliorate any negative socio-cultural impacts of development on the Aboriginal people, for example through the implementation of recommendations of the Kakadu Regional Social Impact Study (Commonwealth of Australia, 1999a; World Heritage Committee, 1998). It is important also that the traditional owners and the Board of Management can set the pace and direction of tourism and ensure that the close liaison with Aboriginal groups continues. Proper consultation with the traditional owners remains vital when issues affecting the management of their land are being considered. 


\section{References}

Boekel, C. (1990). Traditional Aboriginal Land Management Practices in Australian National Parks. PARKS 1: 11-15.

Commonwealth of Australia (1986). Kakadu National Park Plan of Management. Australian National Parks and Wildlife Service. 197pp.

Commonwealth of Australia (1991). Kakadu National Park Plan of Management. Australian National Parks and Wildlife Service/Kakadu National Park Board of Management.171pp.

Commonwealth of Australia (1997). Kakadu National Park Plan of Management 1997. 153pp. http://www.biodiversity.environment.gov.au/kakadu/kakady/pom.html.

Commonwealth of Australia (1999a). Australia's Kakadu - Protecting World Heritage. Response by the Government of Australia to the UNESCO World Heritage Committee regarding Kakadu National Park. http://www.biodiversity.environment. gov.au/kakadu/jabiluka/response.html.

Commonwealth of Australia (1999b). Australia's Aboriginal and Torres Strait Islander Peoples Fact Sheets 1-14. Department of Foreign Affairs and Trade. http://www.dfat.gov.au/aboriginal_facts/index.html.

DASETT (1991). Nomination of Kakadu National Park by the Government of Australia for inscription in the World Heritage List. Prepared by the Australian National Parks and Wildlife Service, Department of the Arts, Sport, the Environment, Tourism and Territories. $157 \mathrm{pp}$.

Davies, J., Higginbottom, K, Noack, D, Ross, H. and Young, E. (1999). Sustaining Eden: Indigenous Community Wildlife Management in Australia. Evaluating Eden Series no.1.

Edwards, R. (1978). Aboriginal Rock Art of the Kakadu National Park. Habitat 6.

Environment Australia Online (2000). Biodiversity Group. http://www.biodiversity. environment.gov, au/bg/.

Hill, M.A. and Press, A.J. (1994). Kakadu National Park - A History. Biodiversitybroadening the debate 2:4-23. http://www.erin.gov.au/life/general_info/biod_debate/ Kakadu.html.

IUCN (1992) Protected Areas of the World: A review of national systems. Volume 1: Indomalaya, Oceania, Australia and Antarctic. IUCN, Gland, Switzerland and Cambridge, UK. xx + 352pp.

Lam, H (1997). Kakadu National Park and the Gagudju. http://www.geocities.com/ CapitolHill/9900/index.html.

World Heritage Committee (1998). Report on the mission to Kakadu National Park, Australia, 26 October - 1 November 1998. UNESCO World Heritage Committee Twenty-second session, Kyoto, Japan, 30 November - 5 December 1998. 25pp. http://www.biodiversity.environment.gov.au/kakadu/jabiluka/unesco.html. 




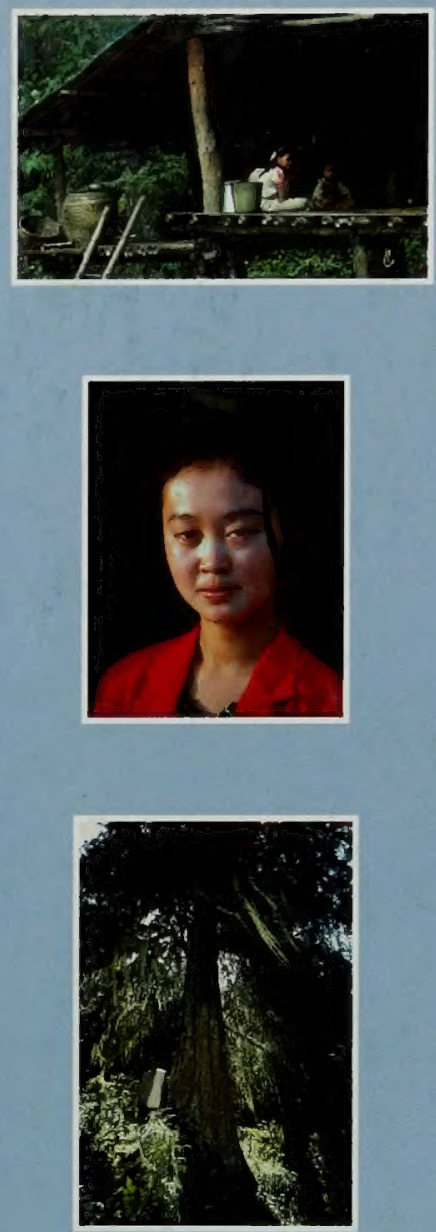

\section{Indigenous and other traditional peoples are a valuable source of knowledge and could greatly contribute to the effective management of protected areas. Seeking that contribution should be a priority for protected area authorities and managers.}

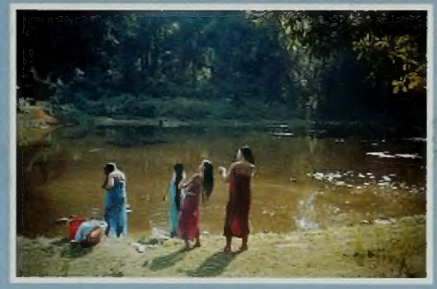

IUCN Protected Areas Programme

Rue Mauverney 28

CH-1196 Gland, Switzerland

Tel: + 41229990001

Fax: + 41229990015

E-mail: mail@hq.iucn.org
IUCN Publications Services Unit 219 c Huntingdon Road Cambridge, CB3 ODL, UK

Tel: + 441223277894

Fax: + 441223277175

E-mail: info@books.iucn.org 